University of South Florida

DIGITAL COMMONS @ UNIVERSITY OF SOUTH FLORIDA
Digital Commons @ University of South Florida

\title{
2003 Transportation Management Association Survey
}

CUTR

Follow this and additional works at: https://digitalcommons.usf.edu/cutr_nctr

\section{Recommended Citation}

"2003 Transportation Management Association Survey," National Center for Transit Research (NCTR) Report No. CUTR-NCTR-RR-2003-08, Center for Urban Transportation Research, University of South Florida, 2004.

DOI: https://doi.org/10.5038/CUTR-NCTR-RR-2003-08

Available at: https://scholarcommons.usf.edu/cutr_nctr/33

This Technical Report is brought to you for free and open access by the National Center for Transit Research (NCTR) Archive (2000-2020) at Digital Commons @ University of South Florida. It has been accepted for inclusion in Research Reports by an authorized administrator of Digital Commons @ University of South Florida. For more information, please contact digitalcommons@usf.edu. 


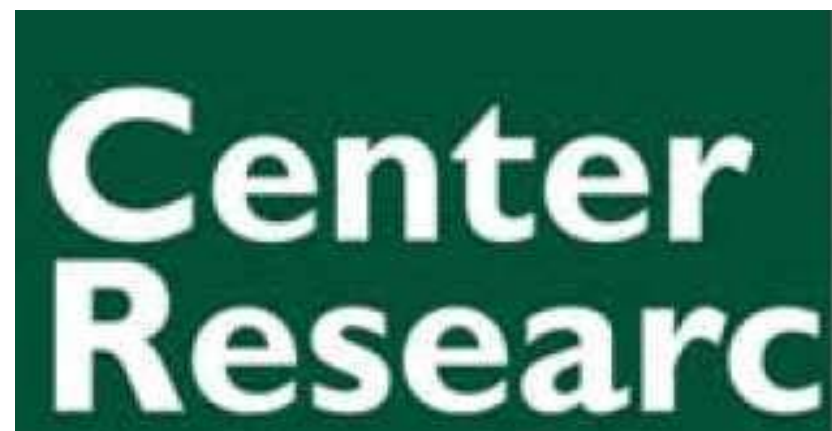

National Center Transit Resear

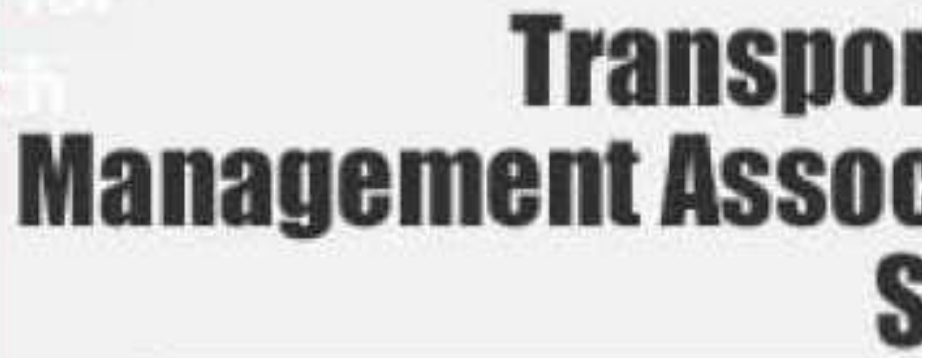

nter for

search

National Center for

Transit Research

\section{National Center} for Transit Research

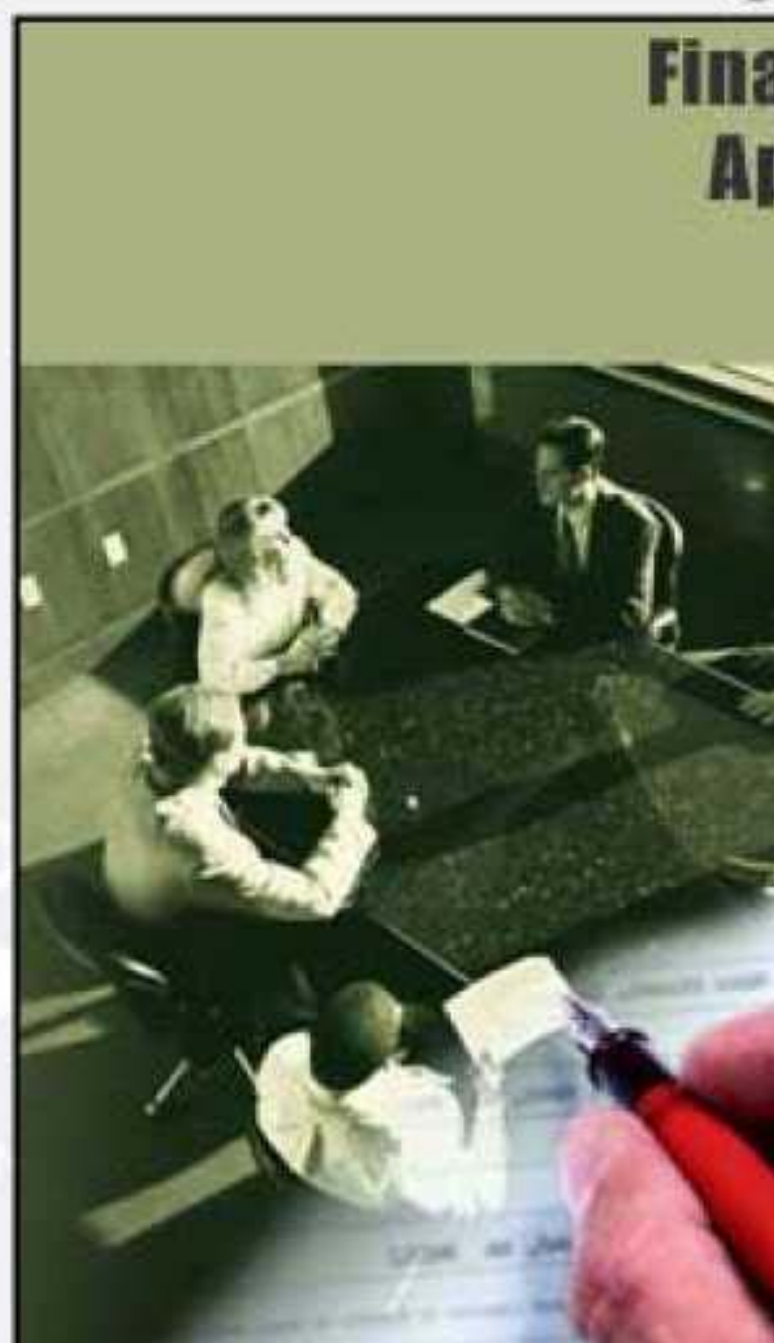


2003

Transportation Management Association (TMA) Survey

\title{
Final Report \\ of the
}

National TDM and Telework Clearinghouse

\author{
Prepared in association with the \\ Association for Commuter Transportation
}

Sara J. Hendricks

Principal Investigator

Susan Pederson-Stahl

Graduate Student Assistant

April 2004

Prepared with spons ors hip from the Florida Department of Transportation

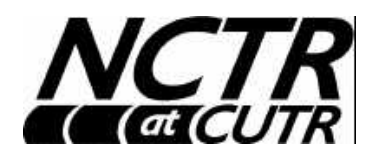

\section{CENTER FOR URBAN TRANSPORTATION RESEARCH}

University of South Florida

4202 E. Fowler Avenue, CUT 100

Tampa, FL 33620-5375

(813) 974-3120, SunCom 574-3120, Fax (813) 974-5168

Edward Mierzejewski, CUTR Director

Joel Volinski, NCTR Director

Philip Winters, TDM Program Director, National TDM and Telework Clearinghouse

The contents of this report reflect the views of the author, who is responsible for the facts and the accuracy of the information presented herein. This document is disseminated under the sponsorship of the Department of Transportation, University Research Institute Program, in the interest of information exchange. The U.S. Government assumes no liability for the contents or use thereof. 
TECHNICAL REPORT STANDARD TITLE PAGE

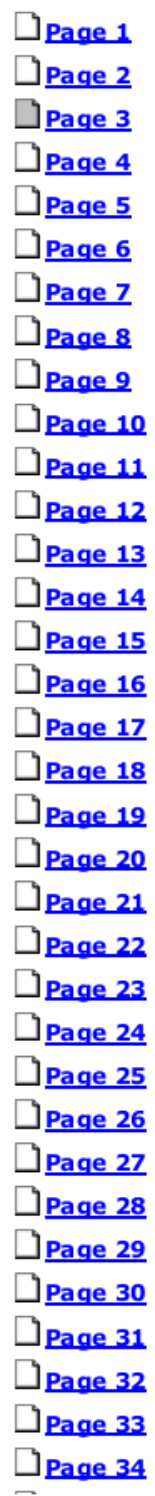

\begin{tabular}{|c|c|c|c|}
\hline $\begin{array}{l}\text { 1.Report No. } \\
\text { NCTR 526-10-1 }\end{array}$ & \multicolumn{2}{|c|}{ 2. Government Accession No. } & 3.Recipient's Catalog No. \\
\hline \multicolumn{3}{|l|}{ 4.Title and Subtitle } & 5.Report Date \\
\hline \multirow{2}{*}{\multicolumn{3}{|c|}{ Results of the 2003 TMA Survey }} & April 2004 \\
\hline & & & 6.Performing Organization Code \\
\hline \multicolumn{3}{|l|}{$\begin{array}{l}\text { 7.Author(s) } \\
\text { Sara J. Hendricks }\end{array}$} & $\begin{array}{l}\text { 8.Performing Organization } \\
\text { Report No. }\end{array}$ \\
\hline \multicolumn{3}{|c|}{ 9.Performing Organization Name and Address } & 10. Work Unit No. \\
\hline \multicolumn{3}{|l|}{$\begin{array}{l}\text { National Center for Transit Research } \\
\text { Center for Urban Transportation Research } \\
\text { University of South Florida } \\
4202 \text { E. Fowler Avenue, CUT } 100 \\
\text { Tampa, FL 33620-5375 }\end{array}$} & $\begin{array}{l}\text { 11.Contract or Grant No. } \\
\text { DTRS98-G-0032 }\end{array}$ \\
\hline \multirow{2}{*}{\multicolumn{3}{|c|}{$\begin{array}{l}\text { 12.Sponsoring Agency Name and Address } \\
\text { Office of Research and Special Programs } \\
\text { U.S. Department of Transportation, Washington, D.C. } 20690 \\
\text { Florida Department of Transportation } \\
605 \text { Suwannee Street, MS 26, Tallahassee, FL } 32399\end{array}$}} & $\begin{array}{l}\text { 13. Type of Report and Period } \\
\text { Covered }\end{array}$ \\
\hline & & & 14.Sponsoring Agency Code \\
\hline \multicolumn{4}{|l|}{$\begin{array}{l}\text { 15.Supplementary Notes } \\
\text { Supported by a grant from the Florida De }\end{array}$} \\
\hline \multicolumn{4}{|l|}{ 16.Abstract } \\
\hline \multicolumn{4}{|c|}{$\begin{array}{l}\text { This report provides the results of a survey that was conducted in the Spring of } 2003 \text {, inviting all TM As in the } \\
\text { United States and Canada to participate. A total of } 97 \text { out of approximately } 146 \text { known American TM As } \\
\text { participated and } 7 \text { out of } 8 \text { known Canadian TM As participated. The survey contained } 70 \text { questions on the topics } \\
\text { of membership, services, personnel and policies, financial characteristics, and organizational characteristics. The } \\
\text { general model for TMA development and operations is shared by both U.S. and Canadian TMAs. The central } \\
\text { focus of U.S. TMAs remains policy leadership, advocacy and service provision. Survey results showed a } \\
\text { continuing trend toward diversification of geographic service area definition, offered services, member groups, } \\
\text { range in membership size, membership definition and travel markets. TMAs have made progress in securing } \\
\text { adequate support staffing, incorporating the use of new technologies to achieve their missions and in the } \\
\text { development of adequate compensation and benefits packages for TM A staff. More TM As are now conducting } \\
\text { emp loyee evaluations and program/services evaluations. Less progress has been made in the area of following } \\
\text { principles of association management, such as conducting work plans and strategic planning processes. Less } \\
\text { progress has also been made in the area of developing dues and non-grant funding sources. }\end{array}$} \\
\hline 17.Key Words & \multirow{2}{*}{\multicolumn{3}{|c|}{$\begin{array}{l}\text { 18.Distribution Statement } \\
\text { Available to the public through the National Technical Information Service } \\
\text { (NTIS),5285 Port Royal Road, Springfield, VA } 22181 \mathrm{ph} \text { (703) } 487-4650\end{array}$}} \\
\hline $\begin{array}{l}\text { Transportation management } \\
\text { association, transportation demand } \\
\text { management }\end{array}$ & & & \\
\hline $\begin{array}{l}\text { 19.Security Classif. (of this report) } \\
\text { Unclassified }\end{array}$ & $\begin{array}{l}\text { 20.Security Classif. (of } \\
\text { this page) } \\
\text { Unclassified }\end{array}$ & $\begin{array}{l}\text { 21.No. of pages } \\
136\end{array}$ & 22. Price \\
\hline
\end{tabular}

Form DOT F 1700.7 (8-69) 
page index | bookmark

$\square$ Page 1

$\square$ Page 2

$\square$ Page 3

$\checkmark$ Page 4

$\square$ Page 5

7 Page 6

$\triangle$ Page 7

$\square$ Page 8

$\square$ Page 9

$\triangle$ Page 10

$\square$ Page 11

$\square$ Page 12

Dage 13

$\square$ Page 14

Dage 15

1 Page 16

$\square$ Page 17

$\square$ Page 18

$D$ page 19

$D$ Page 20

$\triangle$ Page 21

$\triangle$ Page 22

$\square$ Page 23

$\square$ Page 24

$\square$ Page 25

$\triangle$ Page 26

$\square$ Page 27

$\triangle$ Page 28

$\triangle$ Page 29

$\triangle$ Page 30

Page 31

$\square$ Page 32

Page 33

$\square$ Page 34

2003 Transportation Management Association (TMA) Survey

Table of Contents

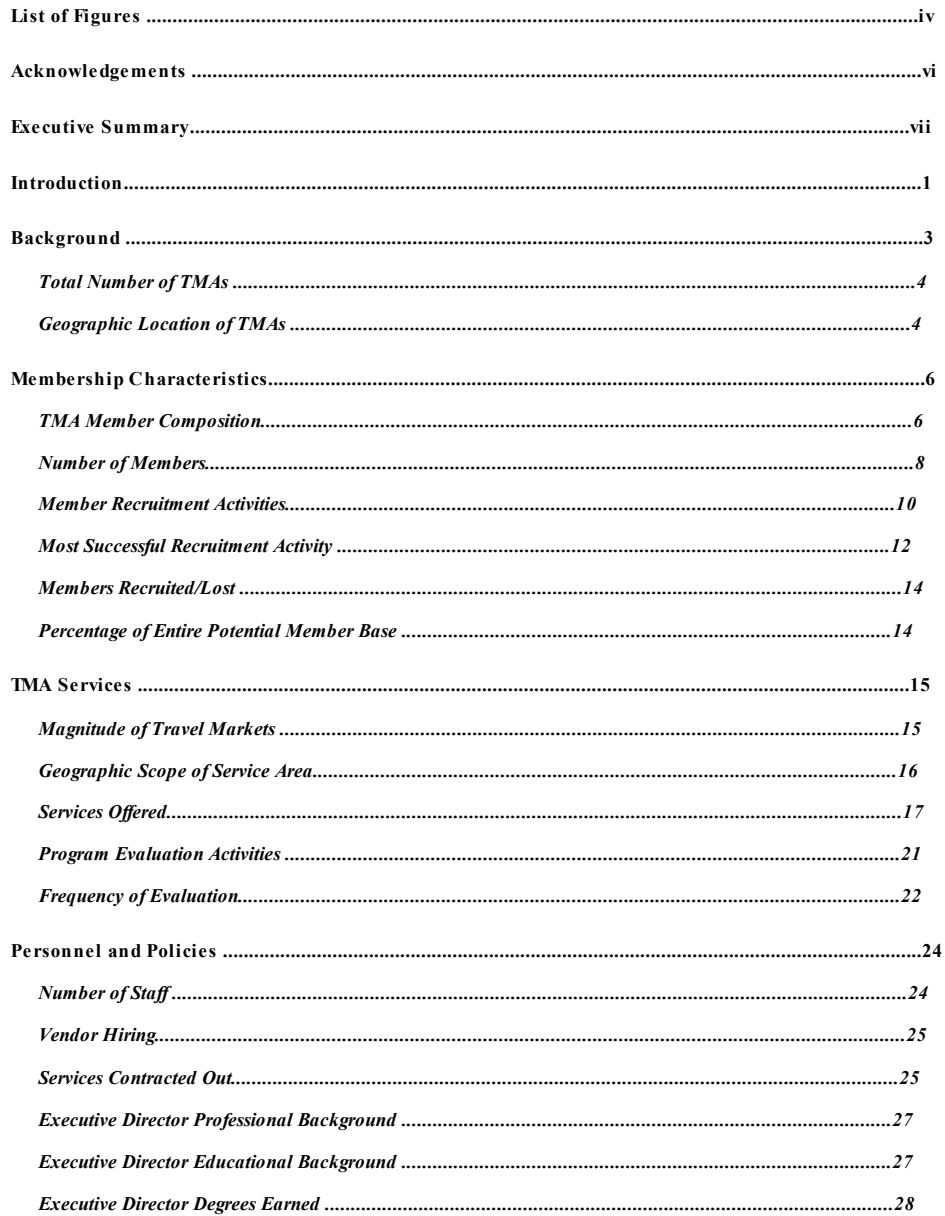


page index I bookmark

$\square$ Page 1

$\square$ Page 2

$\square$ Page 3

$\square$ Page 4

$\triangle$ Page 5

Page 6

$\square$ Page 7

Page 8

$\square$ Page 9

Dage 10

$\square$ Page 11

Page 12

Dage 13

Dage 14

Dage 15

Dage 16

$\square$ Page 17

$\square$ Page 18

Dage 19

$D$ Page 20

$\triangle$ Page 21

$\triangle$ Page 22

$\triangle$ Page 23

$\square$ Page 24

$\triangle$ Page 25

$\triangle$ Page 26

$\triangle$ Page 27

$\triangle$ Page 28

$\triangle$ Page 29

$\triangle$ Page 30

Page 31

$\square$ Page 32

Page 33

$\square$ Page 34
2003 Transportation Management Association (TMA) Survey

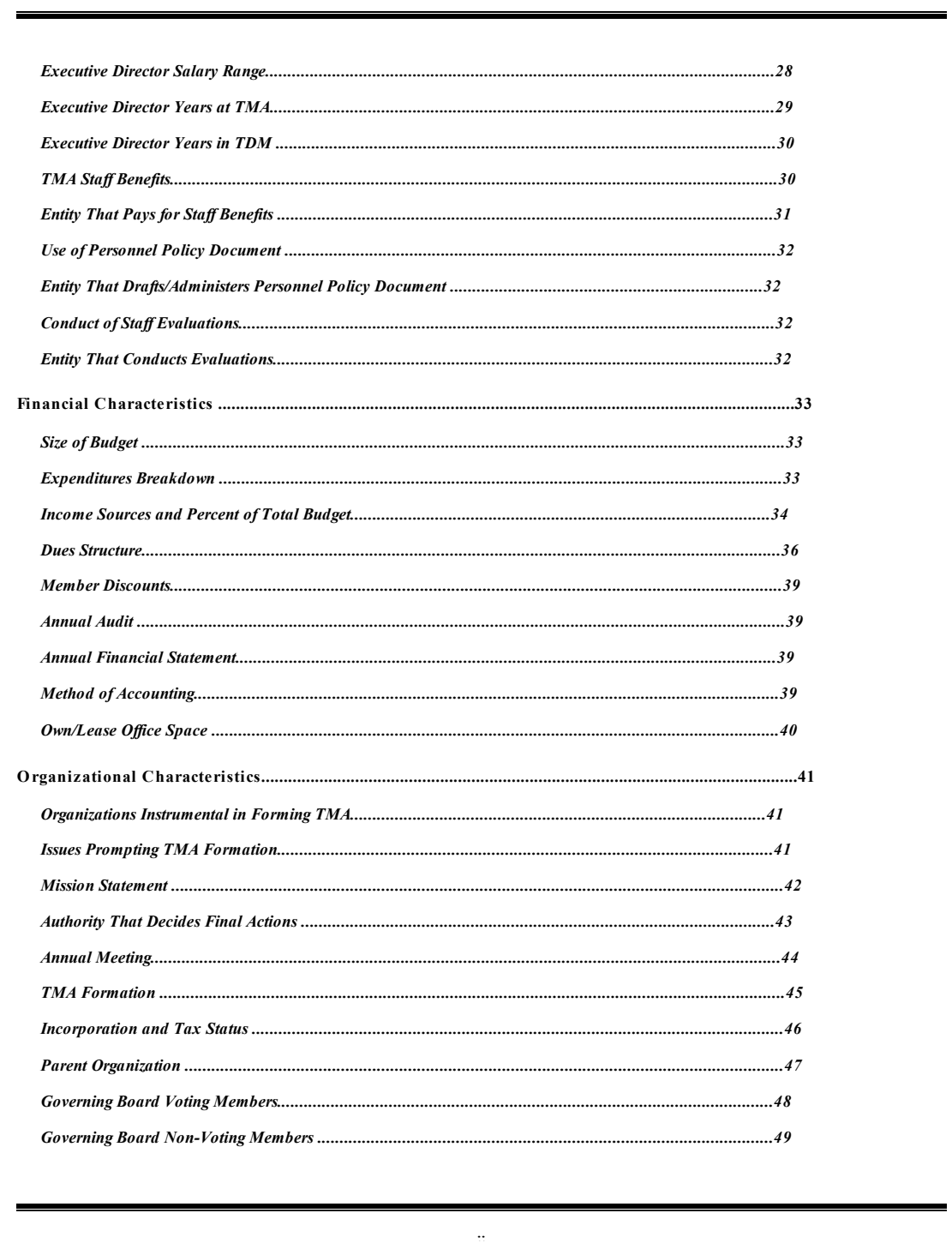


page index I bookmark

$\square$ Page 1

$\square$ Page 2

$\square$ Page 3

$\square$ Page 4

$\square$ Page 5

$\square$ Page 6

Page 7

Page 8

$\square$ Page 9

$\triangle$ Page 10

$\square$ Page 11

Page 12

Page 13

$D$ Page 14

Dage 15

$\square$ Page 16

$\square$ Page 17

$\square$ Page 18

Dage 19

$\square$ Page 20

$\square$ Page 21

$\triangle$ Page 22

$\triangle$ Page 23

$\square$ Page 24

$\triangle$ Page 25

$\triangle$ Page 26

$\triangle$ Page 27

$\triangle$ Page 28

$\triangle$ Page 29

$\triangle$ Page 30

Page 31

$\square$ Page 32

Page 33

$\square$ Page 34
2003 Transportation Management Association (TMA) Survey

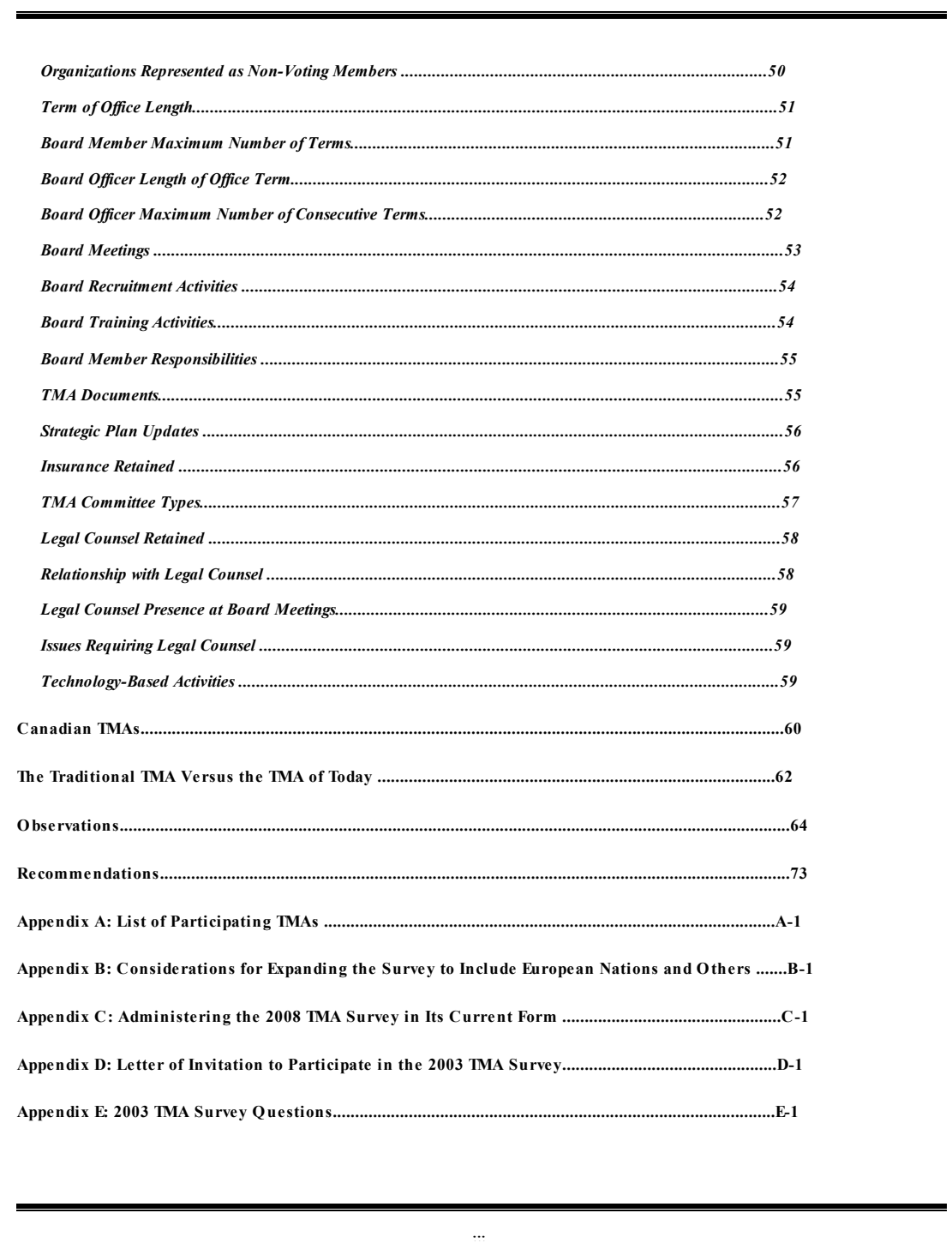


Dage 1

$\square$ Page 2

$\triangle$ Page 3

$\checkmark$ Page 4

$\square$ Page 5

7 Page 6

7 Page 7

Page 8

$\triangle$ Page 9

$\checkmark$ Page 10

$\checkmark$ Page 11

Page 12

1 Page 13

Page 14

$\square$ Page 15

$\square$ Page 16

1 Page 17

Page 18

1 Page 19

$\square$ Page 20

$\square$ Page 21

$\square$ Page 22

$D$ Page 23

$\checkmark$ Page 24

Page 25

$\square$ Page 26

7 Page 27

Page 28

$D$ Page 29

7 Page 30

$\checkmark$ page 31

$\checkmark$ Page 32

Page 33

Dage 34
2003 Transportation Management Association (TMA) Survey

\section{List of Figures}

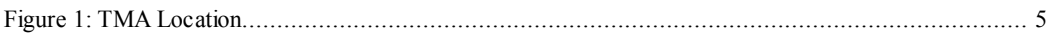

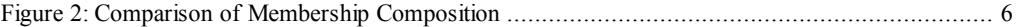

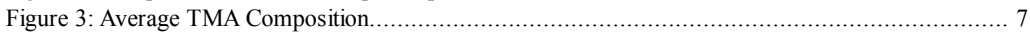

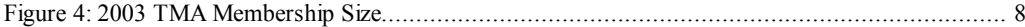

Figure 5: Number of Members by Category of Membership .............................................. 9

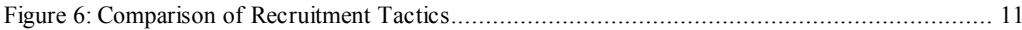

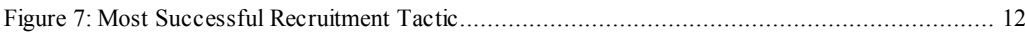

Figure 8: Comparisons of Most Successful Recruiting Method........................................... 13

Figure 9: Magnitude of Potential Customer Base of TMAs .......................................... 15

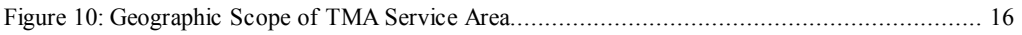

Figure 11: Comparison of TMA Scope of Service Area .................................................... 17

Figure 12: Percentage of Responding TMAs That Offer Service........................................... 19

Figure 13: Services Increasingly Offered by TMAs............................................................... 20

Figure 14: Services Offered Less by TMAs ..................................................................... 21

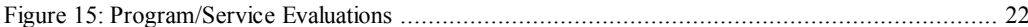

Figure 16: Frequency of Evaluations or Assessments ......................................................... 23

Figure 17: Percentage of TMAs with Numbers of Staff (Full-time and part-time combined)..... 24

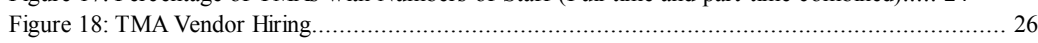

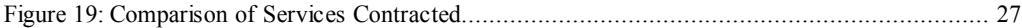

Figure 20: TMA Executive Director Educational Background ............................................... 28

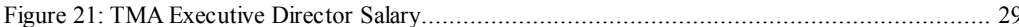

Figure 22: Benefits Provided to TMA Staff ....................................................................... 31

Figure 23: Percentage of Total Budget in 2003 ..................................................................... 34

Figure 24: Percentage of TMA Income Derived From Various Sources ............................... 35

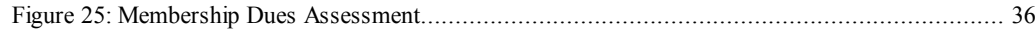

Figure 26: Sample Member Fees Assessed By Range of Number of Employees....................... 37

Figure 27: Comparison of Use of Dues Assessment Types............................................... 38

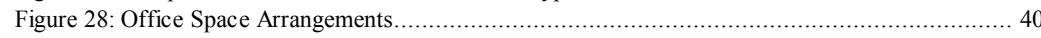

Figure 29: Issues Prompting TMA Formation......................................................... 42

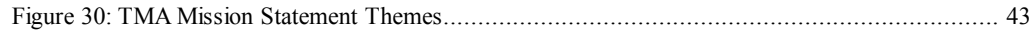

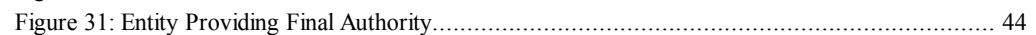

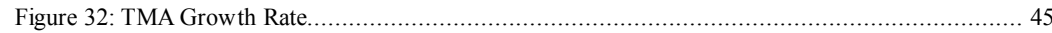

Figure 33: Comparison of TMA Incorporation Status........................................................... 46

Figure 34: Status of TMA Incorporation ............................................................. 47

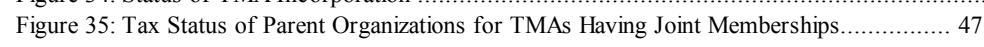

Figure 36: Distribution in Numbers of TMA Board Voting Members.................................... 49

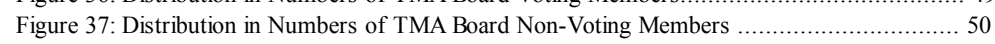

Figure 38: Percentage of TMAs with Non-Voting Board Member Types .............................. 50

36

47

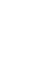

(1)

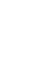

9

4

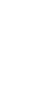

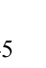


page index I bookmark

Page 1

$\square$ Page 2

Page 3

$\square$ Page 4

$\square$ Page 5

Dage 6

Page 7

Page 8

$\square$ Page 9

$\square$ Page 10

$\square$ page 11

$\square$ Page 12

$\square$ Page 13

$\square$ Page 14

$\square$ Page 15

$\square$ Page 16

$\square$ Page 17

$\square$ Page 18

$\square$ Page 19

$\square$ Page 20

$\square$ Page 21

$\square$ page 22

$\square$ Page 23

$\square$ Page 24

$\square$ Page 25

$\square$ page 26

$\square$ Page 27

$\square$ Page 28

$\square$ Page 29

$\square$ page 30

$\square$ page 31

$\square$ page 32

$\square$ Page 33

$\square$ Page 34
2003 Transportation Management Association (TMA) Survey

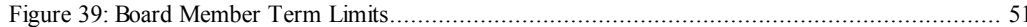

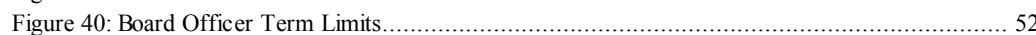

Figure 41: Number of Required Board Meeting Times Per Year............................................. 53

Figure 42: Board Recruitment Activities............................................................................ 54

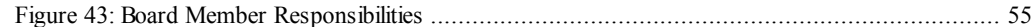

Figure 44: Comparison of Governing Documents Used...................................................... 56

Figure 45: Comparison of Legal Counsel Used.................................................................. 58

Figure 46: Comparison of 1993 Recommendations and Progress Made By 2003 .................... 65

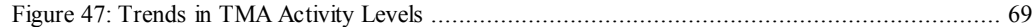

Figure 48: Use of Recruitment Tactic by Percentage of TMAs ................................................ 70 
$\square$ page 1

$\square$ Page 2

$\triangle$ Page 3

$\square$ Page 4

$\square$ Page 5

Page 6

1 Page 7

Page 8

Page 9

7 Page 10

Dage 11

Dage 12

Dage 13

Dage 14

Page 15

Dage 16

Page 17

Dage 18

Page 19

Page 20

Page 21

Page 22

Page 23

$\square$ Page 24

Page 25

$D$ Page 26

Page 27

Page 28

Page 29

Page 30

Page 31

Page 32

Page 33

Page 34
2003 Transportation Management Association (TMA) Survey

\section{Acknowledgements}

The 2003 Transportation Management Association (TMA) Survey was prepared in association with the Association for Commuter Transportation (ACT). The survey was sponsored by the Florida Department of Transportation and funded by the National Center for Transit Research (NCTR) at the University of South Florida in Tampa. Draft survey review and assistance with locating TMAs nationwide was provided by Christopher Park of the Warner Center TMO, Lori Diggins of LDA Consulting, Stuart Anderson of ACT, Kevin Luten of ACT, and Phil Winters of the Center for Urban Transportation Research (CUTR). Andrée Henri of l'Agence métropolitaine de transport provided contact information for Canadian TMAs and European TDM professionals. Susan Pederson-Stahl, graduate student assistant at CUTR, provided assistance with researching and compiling the mailing list and data tabulation of survey results. Special thanks is extended to the 104 executive directors and staff persons of TMAs internationally who volunteered their time to complete an especially long and complex survey and without whose assistance, this study of TMAs would not have been possible. 


\section{Executive Summary}

This report provides the final results for all questions of the 2003 Transportation Management Association (TMA) Survey. The survey was conducted in association with the Association for Commuter Transportation. It was funded by the National Center for Transit Research at the University of South Florida. This report includes an interpretive analysis of results for TMAs in the United States and Canada. The response rate for U.S. TMAs was 97 out of a total of 146, or 66 percent. The 1993 TMA Survey identified 140 TMAs in existence and the 1998 TMA Survey identified 135 TMAs in existence, indicating that while some new TMAs formed and some older TMAs disbanded, the net number of TMAs increased by less than five percent over the past ten years.

In the U.S., at least one TMA is located within 29 states and half of all U.S. TMAs are in one of four states that have strong air quality or land use regulatory environments. In Canada, there are eight TMAs, seven of which responded to the survey. Three TMAs are located in Vancouver, British Columbia, three more TMAs are located in Montréal, Québec, one TMA is located in Toronto, Ontario and one TMA is located in Halifax, Nova Scotia. Canadian TMAs are generally younger than their U.S. counterparts and mostly operate on smaller budgets within a larger parent organization. While the majority of U.S. TMAs are incorporated non-profit organizations, most Canadian TMAs operate within parent organizations. Correspondingly, while the final authority for deciding most U.S. TMA actions rests with the members only, the final authority for deciding actions of most Canadian TMAs is shared with the government or an advisory committee. While the largest group of members in U.S. TMAs is business employers, the largest group of members of Canadian TMAs is government employers. Canadian TMAs serve generally smaller travel markets than U.S. TMAs, with a focus on serving commuters rather than other travel markets. The missions of some Canadian TMAs differ somewhat from the U.S. TMAs in that there is an additional emphasis on public health and well being that is not as much articulated by U.S. TMAs. Correspondingly, Canadian TMA staff members represent more prevalent professional backgrounds in teaching and environmental studies, while the professional emphasis in the U.S. is marketing.

Despite these differences between Canadian TMAs and U.S. TMAs, the general model for TMA development and operations is shared by both nations, especially when contrasted with the strikingly different manner of service delivery by European nations. The similarities are particularly strong in the area of service provision. Mobility management services in European nations are generally provided through individual entities rather than partnerships. This difference might require the TMA survey instrument to be modified in order to include European activities in future surveys. Appendix B provides further discussion. 
The central focus of U.S. TMAs remains policy leadership, advocacy and service provision. The most commonly offered services are promotional materials and events, rideshare matching, guaranteed ride home and regiona/local advocacy. While direct shuttle service operation is among the least frequently offered services, it is still offered by 29 percent of all responding TMAs. This is a higher proportion of TMAs with shuttle services than in 1998. Larger TMA budgets are associated with the provision of transit services. We also are seeing a broader range in services offered by TMAs due to efforts to test creative service ideas and harness technological advances as well as appeal to a more diversified membership.

While the mission of the TMA Survey was to attempt to draw generalizations about TMAs, perhaps the most striking feature described by the data is the flexibility of TMA organizational structure and diversity of operational characteristics while pursuing roughly similar missions. However, the apparent trend toward increasing diversity of TMAs as characterized by the 2003 TMA Survey may be overstated and not necessarily reflect true changes in TMAs over the past ten years. This is due to the inclusiveness of the most recent definition of a TMA in the TMA Handbook, so that more diverse organizations considering themselves TMAs have responded who otherwise might not have. Also, the expansion of answer options in the 2003 TMA Survey may appear to indicate changes and increasing diversity of TMAs over the years, when in reality, the responses may more closely specify the nature of the TMA as it has been all along. Having provided this caveat, the 2003 TMA Survey results indicated a continuing trend toward increasing diversification of TMA operational characteristics, including:

Diversified geographic service area definitions

Expansion of service types

Diversified member groups

Enlarged range in membership size

Differing membership definitions

Diversified travel markets in addition to commuters

The 2003 TMA Survey indicates that TMAs have made progress in securing more adequate support staffing, incorporating the use of new technologies to achieve their missions and in the development of adequate compensation and benefit packages for TMA staff. Also on the positive side, a larger proportion of TMAs are conducting program evaluations. This is indicative of members and funders wanting greater accountability regarding the outcome of programs and the results of their investments. Additionally, TMA staff sees the desirability of information gained through evaluation as a tool to publicize program benefits as well as to improve and refine programs and services. A larger proportion of TMAs are also conducting employee evaluations. This is a positive sign for TMA professionals because it conveys a greater effort toward objectivity and consistency of evaluation, which will reward highperforming TMA staff while providing guidance on areas for improvement. 
In 1993, the average TMA was incorporated with a high degree of organizational administration through the use of governing documents. By 2003, the average TMA was still incorporated but there were an increasing number of TMAs operating informally. This may be due to the desire to demonstrate results quickly through programs and services by sidestepping the effort involved in setting up the administrative structure of an independent non-profit. Little progress has been made toward the 1993 recommendation to follow principles of association management. This is evidenced by a decreased use of governing documents. Approximately 40 percent of TMAs indicated that they do not use an annual or 2-year work plan and 24 percent of TMAs with budgets larger than $\$ 300,000$ do not have strategic plans. Regardless of the degree of formality of the TMA organization, yearly work plans and strategic planning are valuable tools. They require a degree of reflection and forethought to ensure the work of the TMA stays focused. Most TMAs should develop work plans and conduct strategic planning processes.

Less progress has also been made in developing dues and non-grant funding sources. This may be due to a greater reliance on government funding than in 1993, which may enable TMAs to concentrate immediately on service provision rather than organizational administration. The average TMA in 2003 had fewer members but with a greater diversification of geographic service area definition and of member types. Business employers held a lesser majority of TMA membership in 2003 than ten years prior, with a larger percentage from groups that have less financial resources and political clout.

The decrease in revenues from member dues is likely associated with the corresponding decrease in business employers and developers as member groups, who would pay higher dues fees than fee rates established for other member groups (i.e., non-profits). The income source that appears to make up the difference is government funding. This is not a positive sign for TMAs because government as a TMA "customer" represents the general public, which is a far less specified, more nebulous target market than developers and business owners. If a business member withdraws from membership, the TMA loses the income derived from the dues of one member. But a far too large proportion of a TMA budget in the form of a large grant may be controlled by one or a few government entities. Its withdrawal could spell disaster for the TMA. For example, the effective work of many TMAs that have assisted regions to attain federal air quality standards may mean their doom as TMAs become less likely to receive Congestion Mitigation and Air Quality grants.

The study identified elements of increased or decreased activity on the part of TMAs as summarized in the table below. 
$\square$ page 1

Page 2

$\triangle$ Page 3

$\triangle$ Page 4

Page 5

$\triangle$ Page 6

Page 7

Page 8

$\square$ Page 9

Page 10

Dage 11

Page 12

Page 13

Dage 14

Dage 15

Dage 16

Page 17

Dage 18

7 Page 19

Dage 20

1 Page 21

$\square$ Page 22

Page 23

$\square$ Page 24

Dage 25

7 Page 26

Page 27

$\triangle$ Page 28

Page 29

Page 30

$\square$ Page 31

$\square$ Page 32

Page 33

$\triangle$ Page 34
2003 Transportation Management Association (TMA) Survey

Trends in TMA Activities

\begin{tabular}{|c|c|}
\hline Decreases in Activity & Increases in Activity \\
\hline 2๑ Membership size & 20 Board size \\
\hline 20 Volunteer staffing & 20 Paid staffing \\
\hline 20 Peer-to-peer member recruiting & 20 Board chair recruiting \\
\hline $2 \odot$ Annual meetings & 2. Use of personnel policy documents \\
\hline 2. Board meetings & 2. Use of employee evaluations \\
\hline 2. Committee work & 2. Use of program/services evaluations \\
\hline $\begin{array}{l}\text { 20 Contracts with vendors for TMA } \\
\text { staffing }\end{array}$ & $\begin{array}{l}\text { 20ntracts with vendors for service } \\
\text { delivery }\end{array}$ \\
\hline 20. Use of dues & \\
\hline 2. Strategic planning & \\
\hline 20 Use of governing documents & \\
\hline 2. Annual audit & \\
\hline 2. Annual financial report & \\
\hline 20 TMA incorporation & \\
\hline 2. Use of volunteer legal counsel & \\
\hline
\end{tabular}

In 2003, the observed combination of larger permanent paid staffs, fewer TMA members, less reliance on volunteer and committees, less reliance on dues as an income source, less board meetings, and less peer-to-peer member recruitment appear to indicate a general decrease in involvement by the TMA membership and a larger balance of the work done by TMA staff. Decreased member activity may mean either satisfaction resulting from issue resolution or a membership in need of rejuvenation. Over 60 percent of TMAs do not provide some kind of board training. Just 5 percent of TMAs have set a maximum number of terms for board officers.

TMAs have larger permanent staffs than they used to. While this is a positive sign that TMAs have more stable and ample resources to carry out their missions, it also makes it easier for a tired or uninspired TMA board to lean more upon the staff to "carry the torch". Within a TMA service area there may be only a small number of TMA leaders among the membership that can ably champion the organization at any one time. This underscores the necessity of TMAs to always be looking closely at the service needs of the membership to determine ways to revitalize the appeal and role of the TMA in the business community.

In the later 1980's and early 1990's, there may have been a higher degree of anticipation over the potential of TMAs, as an organizational structure that can deliver resolution to transportation issues. In 2003, as the relative newness of the TMA concept has matured, a sense of reality has set in that while TMAs can and are effective organizational structures for addressing transportation issues, many of the kinds of problems that TMAs address do not go away 
overnight, if ever. While new problems arise as some old ones are resolved, there are always the continuing problems associated with traffic congestion. TMA effectiveness is commensurate with the degree of ongoing commitment and time that partners are willing to give.

Based upon survey results and observations from the analysis, recommendations were developed with discussion provided. Recommendations were on topics that focused on the fundamentals:

Developing TMA roles and services that members value

Seeking alternative income sources to bolster funding stability

Finding champions in the community to renew TMA leadership

Providing TMA board officer training and term limits

Serving on the MPO board

Conducting annual and strategic planning processes

The 2003 TMA Survey analysis has provided results on the status of TMAs and charted trends in changing characteristics. The aim has been to identify what can be done to improve the current profile of TMA operations. Overall, these results have provided a mixed picture of progress for TMAs, including areas exhibiting clear gains as well as other areas that need to be watched. To maintain proper perspective, the operation of a TMA is not easy work. Resolving transportation issues through partnerships is a tenuous business requiring TMA staff to convince influential people to donate their time, talents, and other valuable resources. TMA staff is called upon to employ an uncommon combination of technical transportation knowledge, marketing, association management and "people skills" to maintain the organization within a constantly shifting economic and political context. At the same time, the struggle is increasing for urban areas to maintain transportation services for growing populations within the constraints of shrinking undeveloped space, limited public funds and complex and costly legal environments. TMAs provide promising opportunities for enterprising communities to craft options through a participatory process. Communities need TMAs more now than before and it is hoped that TMA staff, boards, and funding partners are reassured of the importance of these vanguard efforts. The 2003 TMA Survey results are intended to help TMAs continue their work.

Report appendices provide detailed information regarding the survey methodology, with suggestions on how to improve it for future surveys. Transportation professionals from European nations have expressed interest in survey results. It is considered that future surveys may offer opportunities for increased international collaboration and information transfer. 
Page 1

$\square$ Page 2

$\triangle$ Page 3

$\triangle$ Page 4

$\square$ Page 5

$\square$ Page 6

$\triangle$ Page 7

Page 8

$\triangle$ Page 9

$\triangle$ Page 10

$\checkmark$ Page 11

Page 12

Dage 13

Page 14

Page 15

Dage 16

Page 17

Dage 18

Page 19

Dage 20

Page 21

$\square$ Page 22

Page 23

$\square$ Page 24

Page 25

$D$ Page 26

Page 27

Page 28

Page 29

Page 30

Page 31

Page 32

Page 33

$\square$ Page 34
2003 Transportation Management Association (TMA) Survey

\section{Introduction}

This report provides the final results for all questions of the 2003 Transportation Management Association (TMA) Survey, including an interpretative analysis of results for TMAs in the United States and Canada. The intent of the survey is to make reliable generalizations regarding the organization and operation of TMAs. It gives individual TMAs information on how their organization compares with the national average. This is not to suggest that TMAs should necessarily seek to emulate the national norm. The 2001 TMA Handbook emphasizes the advantages of TMA organizational variation rather than conforming to any particular model. In fact, an "average TMA" is a fictitious TMA. Survey results indicate that all TMAs differ, by at least one quality, from the "average" as aggregated across all responses given by survey participants.

Instead, the information in the survey can illustrate the range of differences among TMAs, demonstrating the organizational flexibility of the TMA concept, and more importantly, provide TMAs with ideas on various options for operating their TMAs. Survey results may also serve to check the pulse of TMA operations and signal positive or negative trends, which constitute issues that should be addressed to strengthen TMAs.

This report contains the results of the analysis in the order in which the questions were listed by topic in the TMA Survey:

Questions 1-6: Address and contact information

Questions 7-13:

Membership

Questions 14-19 Services

Questions 20-31 Personnel and policies

Questions 32-41 Financial characteristics

Questions 42-70 Organization

Starting with question 7, the exact wording of the questions is provided and precedes the survey findings. Questions 13, 19, 31, 41 and 70 were omitted from this report format because these questions asked for additional comments. Instead, the information provided in response to these questions has been incorporated into the text as clarification to related survey questions. Where there was comparative information available from previous years, this was also included. The analysis first examines U.S. TMAs, followed by a separate comparative analysis of Canadian TMAs. The Appendices include:

A list of all participating TMAs with their email and web site addresses provided by them in the survey

A discussion of observations and suggestions for administering the 2008 TMA Survey 
A discussion of considerations for expanding the Survey to include European nations and others

A copy of the letter that was used to invite TMAs to participate in the survey

A copy of the survey instrument

While the 2003 TMA Survey provides a wealth of information, it is important to keep in mind some limitations of the Survey. The TMA Survey comparisons indicate that some changes in the operations and characteristics of TMAs have occurred over the past ten years. However, the Survey results generally do not answer why these changes occurred. For example, we know that letters sent from the Executive Director to prospective members is a recruitment tactic that was used less in 2003 than in 1993. The survey does not tell us why this decrease occurred. In order to identify the reasons for this change, we would have to determine if the TMA answered this question differently in previous surveys, then ask the respondent to explain why this change occurred.

Every effort was made to keep the 2003 TMA Survey consistent with previous surveys. However, changes in the wording of some survey questions may explain differences in answers from 1993 to 2003. In particular, the provision of a greater variety of answer options might result in a decrease in the number of respondents that made a choice from fewer original answer options in previous surveys. For example, some TMAs that answered "specialized activity center" to describe their service area might have checked "suburban" in the 1993 survey when "specialized activity center" was not an answer option. The decrease in the number of respondents checking "suburban" to describe their service area does not necessarily mean that any TMAs redefined their service areas during the last ten years nor that newer TMAs created to serve a specialized activity center took the place of disbanded TMAs that once served suburban service areas. However, the greater number of answer options, while presenting complications in comparing data from 1993 to 2003, does provide us a more detailed picture of the characteristics of TMAs today.

A second reason for changes indicated between 1993 and 2003 could be changes in interpretation of survey questions by the respondent in 1993, compared with the respondent in 2003, since in many cases the TMA Executive Director who responded in 1993 is not the same person who responded in 2003. 


\section{Background}

The TMA Survey has been conducted twice before on behalf of the TMA Council of the Association for Commuter Transportation: in 1993' and in 19982. The Center for Urban Transportation Research at the University of South Florida in Tampa offered to do the 2003 update, funded by a grant from the National Center for Transit Research. The 2003 TMA Survey builds upon this historical data with the intent that this data continue to be collected every five years. As time passes, we will be able to identify emerging trends in the roles and function of TMAs that may better inform us how to improve their operations.

The design of the 2003 TMA Survey was aimed at maintaining consistency of the questions with previous surveys as much as possible to allow for comparison of data from 1998 and 1993. The survey contained 70 questions on the topics of membership, services, personnel and policies, financial characteristics and organizational characteristics. One observation noted by the survey analysts of the previous 1998 TMA Survey, was that a sharp diversity exists among organizations that identify themselves as TMAs. In response to this observation, one change to the 2003 TMA Survey was the addition of more answer options and an "other, please specify _..." answer option wherever possible, to enable respondents to explain in further detail if none of the other answer options provided adequate alternatives. An "Additional comments..." line was also provided at the end of each section, which participants frequently used to qualify and clarify answers given to previous questions, indicating the difficulty that many TMAs had describing their TMAs accurately within the confines of the answer options. TMAs collectively provided 138 clarifications as part of additional comments.

Some organizations initially thought they should not respond to the survey because their organizations were either just in the formation stages, were not dues-collecting or did not have formal memberships. These organizations were encouraged to respond. However, because of this pattern of concern, there is some question whether many other TMAs did not respond to the survey because they did not feel that their organizations fit a traditional profile. The cover letter that accompanied the survey attempted to address the question of whether the survey applied to an organization by referencing the highly flexible and inclusive definition of a TMA, as provided in the 2001 TMA Handbook. According to the Handbook, "A TMA is an organized group applying carefully selected approaches to facilitating the movement of people and goods within

\footnotetext{
'Davidson, Diane, "Common TMA Roles and Procedures", prepared by The TMA Group, Franklin, TN, published in the 1995 TMA Summit Proceedings, Association for Commuter Transportation.

${ }^{2}$ Ungemah, David W. and Stuart M. Anderson, "The Evolving TMA: Results from the 1998 ACT TMA Council Operational Survey", prepared by Urban \& Transportation Consulting, prepared for the Association for Commuter Transportation, TDM Review, Vol. VII, Number 1, Winter, 1999. This article was republished in the appendix of the 2001 TMA Handbook.
} 
an area. TMAs are often legally constituted and frequently led by the private sector in partnership with the public sector to solve transportation problems."

The mail list database of TMAs was developed through several sources, including the ACT member database, the ACT TMA Council contact list, Internet searches, a database of the National TDM and Telework Clearinghouse, contact with state departments of transportation, a question posted to the TDM listserv and through numerous inquiries to peers in the profession and phone calls to verify information. TMAs were invited regardless of ACT membership affiliation. A hard copy and an electronic copy of the survey and cover letter were sent to 227 addresses, including ten contacts in Canada, of which eight were verified as TMAs. Seven of these TMAs responded.

In addition to Canadian TMAs, the survey attempted to include the European experience by sending surveys to 13 known European contacts. However, responses from TDM professionals in Germany and Italy observed that, with the possible exception of The Netherlands, the organizational structure for delivering mobility management services is not similar to the TMA model used in the United States and Canada. One survey from The Netherlands was completed and returned. In general, mobility management services in European nations are delivered not by TMAs or other forms of public-private partnerships but by individual entities, such as a single company offering services to its employees.

\section{Total Number of U.S. TMAs}

A total of 204 American contacts received invitations to participate in the TMA Survey. Ultimately, 65 contacts were later set aside after concluding they were not TMAs. A total of 97 surveys were received from TMAs located in the United States. An additional 49 identified U.S TMAs did not respond. The response rate for U.S. TMAs was 97 out of a total of 146 , or $66 \%$, which is remarkable, considering the length and complexity of the survey. The 1993 TMA Survey identified 140 TMAs in existence and the 1998 TMA Survey identified 135 TMAs in existence, indicating that while some new TMAs formed and some older TMAs disbanded, the net number of TMAs increased by less than five percent over the past ten years.

\section{Ge ographic Location of TMAs}

Based upon survey responses and the development of the database, at least one TMA is located within 29 states and the District of Columbia while no TMAs are located within the remaining 21 states. TMAs tend to be concentrated along the East Coast (51) and the West Coast (40) states. Those states containing 10 or more TMAs include California (31), Massachusetts (15), Florida (14), and Arizona (12). Other states with between five and ten TMAs include Pennsylvania, Georgia, Virginia, Colorado, New Jersey and Oregon. Figure 1 below shows the number and 
page index I bookmark

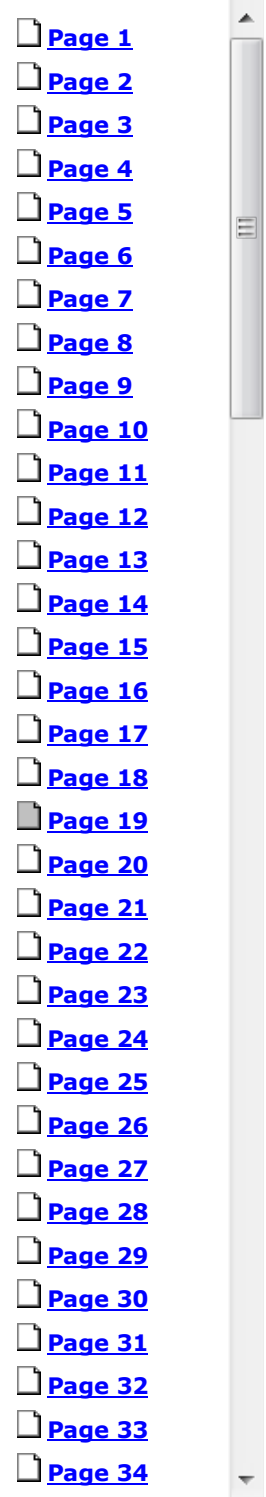

location of all known TMAs in addition to the number of surveys received and their state of origin.

Figure 1: TMA Location

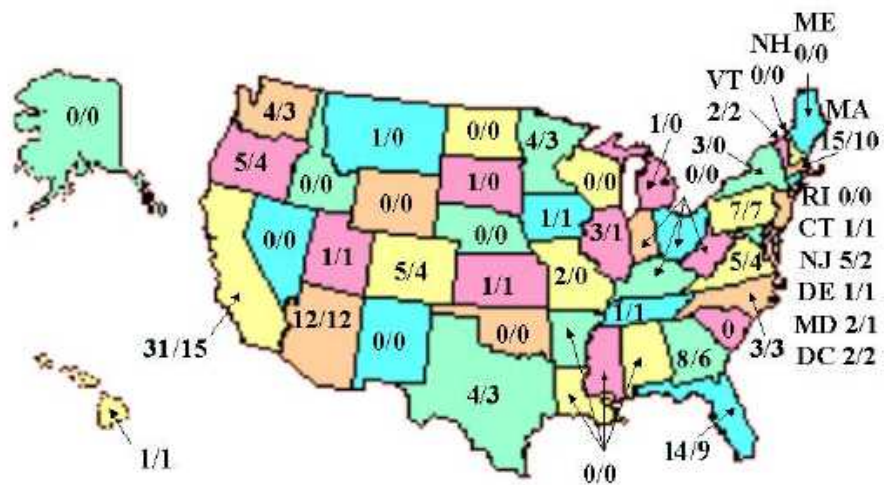

LEGEND

$\mathrm{X} / \mathrm{X}$ TMLAs Identifled/TMAs Responded 
$\square$ page 1

$\square$ Page 2

$\square$ Page 3

$\triangle$ Page 4

Page 5

$D$ Page 6

$\triangle$ Page 7

Page 8

$\triangle$ Page 9

$\checkmark$ Page 10

$\checkmark$ Page 11

Page 12

Dage 13

Page 14

Dage 15

Page 16

Page 17

Dage 18

$\square$ Page 19

Dage 20

$\square$ Page 21

Page 22

$D$ Page 23

$\square$ Page 24

Page 25

$D$ Page 26

Page 27

Page 28

Page 29

Page 30

Page 31

Page 32

Page 33

Page 34
2003 Transportation Management Association (TMA) Survey

\section{Membership Characteristics}

TMA Me mber Composition

7. What is the composition of your membership? (Percent of total members, not travel markets).

The composition of TMA membership, looking collectively across TMAs, indicates that the majority of TMAs include business employers and that business employers tend to be the most highly represented group within a TMA. However, membership composition comparisons with 1993 data in Figure 2 indicate a decrease in the percentage of business employers composing overall membership.

Figure 2: Comparis on of Members hip Composition

\begin{tabular}{|ll|l|}
\hline Member group & $\mathbf{1 9 9 3}$ & $\mathbf{2 0 0 3}$ \\
\hline Business employers & $72 \%$ & $59 \%$ \\
\hline Developers & $10 \%$ & $6 \%$ \\
\hline Government & $8 \%$ & $10 \%$ \\
\hline Chambers of commerce & $2 \%$ & -- \\
\hline Suppliers & $2 \%$ & -- \\
\hline Property owners & -- & $8 \%$ \\
\hline Non-profit organizations & -- & $6 \%$ \\
\hline Residential or community association & -- & $2 \%$ \\
\hline Individuals & -- & $<1 \%$ \\
\hline Other & $6 \%$ & $9 \%$ \\
\hline
\end{tabular}

Looking collectively across all TMAs, Figure 3 shows the membership composition of the aggregate "average" TMA. When we compute averages across all TMAs, 59 percent of TMA membership are business employers, 5 percent are government employers, 5 percent are government agencies, 6 percent are developers, 8 percent are commercial property owners, less than 1 percent are individuals, 6 percent are nonprofit organizations, 2 percent are residential and community association representatives and 9 percent are other. Other is usually unspecified but for those who did specify, the most common answer supplied was universities and educational institutions. In comparison, the 1998 TMA Survey found that 75 percent of TMA membership is derived from business employers. The 2003 TMA Survey provided more answer options and it is possible that the combined percentages for business employers, property owners and government employers and to some degree, other, provides the comparison for the percentage of membership derived from businesses and employers in 1998. The percentage for these groups combined in 2003 is 79.6 percent. 
$\square$ Page 1

$\square$ Page 2

Dage 3

Page 4

Page 5

$\square$ Page 6

$\triangle$ Page 7

$\square$ Page 8

$\triangle$ Page 9

$\checkmark$ Page 10

Page 11

$\checkmark$ Page 12

Dage 13

Dage 14

Dage 15

Dage 16

Page 17

Dage 18

Page 19

Dage 20

Page 21

$\square$ Page 22

Page 23

$\square$ Page 24

Page 25

$D$ Page 26

Page 27

Page 28

Page 29

Page 30

Page 31

Page 32

Page 33

Page 34

Out of the 93 surveys supplying a response to this question, 59 TMAs have from 50-100 percent of their memberships composed of business employers and 12 of these TMAs have 100 percent of their memberships composed of business employers. Another seventeen TMAs have the majority of their memberships from other categories. For example, five TMAs have 100 percent of their memberships composed of commercial property owners. Three TMAs have between 64 and 100 percent of their memberships composed of non-profit organizations. Three TMAs have from 50 to 100 percent of their memberships composed of government agencies. Another TMA has 100 percent of its membership composed of educational institutions. Two TMAs have 50 and 80 percent of their memberships composed of residential or community association representatives. Three TMAs have between 50 and 82 percent of their memberships composed of developers. Three TMAs had memberships under formation. The remaining 14 TMAs have memberships with generally even representation across two or more groups. Fifty-two of the TMAs have memberships composed of three or more groups.

Figure 3: Average TMA Composition

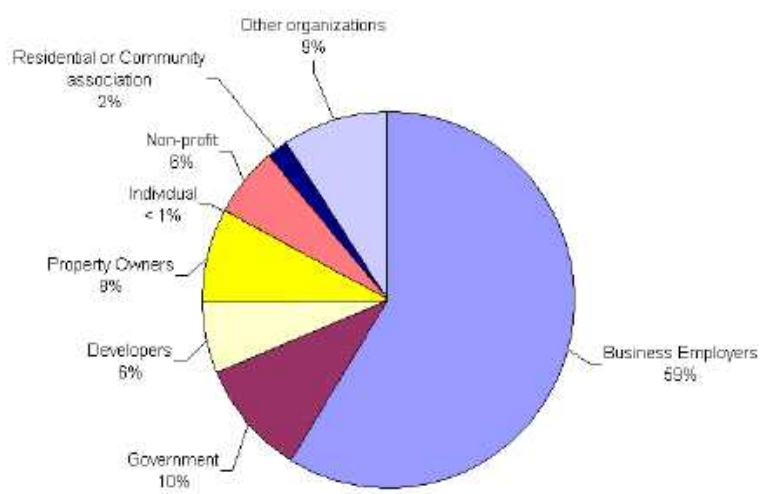


$\square$ Page 1

$\square$ Page 2

$\triangle$ Page 3

$\triangle$ Page 4

$\triangle$ Page 5

$\triangle$ Page 6

$\triangle$ Page 7

Page 8

$D$ Page 9

Dage 10

Page 11

Page 12

Page 13

Page 14

Page 15

Page 16

Page 17

Dage 18

$\square$ Page 19

Dage 20

$\square$ Page 21

$\checkmark$ Page 22

$D$ Page 23

$\square$ Page 24

Page 25

$D$ Page 26

Page 27

Page 28

Page 29

Page 30

Page 31

Page 32

Page 33

$\square$ Page 34
2003 Transportation Management Association (TMA) Survey

Number of Members

8. How many members does your TMA represent?

In 1993, the typical TMA had 20-80 members. This appears to hold less true in 2003 as 65 percent of TMAs had memberships of 40 or less. Figure 4 provides the fuller picture. It shows that while the majority of TMAs had memberships of 40 or less, another 23 percent of TMAs had memberships of 81 and higher. Ten TMAs gave membership sizes ranging from 4,000 to 24,000 .

Figure 4: 2003 TMA Membership Size

\begin{tabular}{|l|l|}
\hline Range in Number of Members & Percentage of TMAs in Range \\
\hline $3-20$ & $42 \%$ \\
\hline $21-40$ & $23 \%$ \\
\hline $41-60$ & $7 \%$ \\
\hline $61-80$ & $5 \%$ \\
\hline 81 and higher & $23 \%$ \\
\hline
\end{tabular}

The seemingly simple question about numbers of members turned out to be one of the most complex questions of the survey to analyze. The question was answered by a wide range of numerical responses in addition to notes. Closer inspection of the surveys indicates that membership size appeared to be defined in five ways, as categorized in Figure 5. Accordingly, the TMAs were divided up into these five groups to attempt more meaningful comparisons. These member groups include the following.

Category 1. Members are the number of participating companies, employers, developers, office building owners, government or non-profit entities. Services are available to employees or residents represented by the member entities. This is perhaps the most traditional member definition for TMAs. These TMAs are usually independent private nonprofits.

Category 2. Members are the same as those serving on the governing board. The TMA provides services to employees, commuters, or other customer groups, regardless of whether these individuals are represented by a board member. These are generally, independent, private nonprofits or in one case a government commission.

Category 3. Members are so by virtue of property ownership within the geographic location of a business improvement district (BID), community improvement district (CID), municipal service district, or owner's association. Membership is mandatory and automatic. 
Dage 1

$\square$ Page 2

$\triangle$ Page 3

$\triangle$ Page 4

$\triangle$ Page 5

$\triangle$ Page 6

$\triangle$ Page 7

Page 8

$\triangle$ Page 9

$\triangle$ Page 10

Page 11

Page 12

Page 13

Page 14

Page 15

Dage 16

Page 17

Dage 18

$\square$ Page 19

Dage 20

Page 21

$\square$ Page 22

Page 23

$\square$ Page 24

Page 25

7 Page 26

Page 27

Page 28

$D$ Page 29

Dage 30

Page 31

Page 32

Page 33

Page 34

Category 4. Members are so by virtue of joint membership in a chamber of commerce or business association (parent organization). In this category, there appear to be shades of difference in the degree of independence of the TMA from its parent organization. Some TMAs function quite independently from the parent organization. There may be some autonomy of decision making by the TMA and there may be some membership distinction between regular chamber members and those who are also active with the TMA. Other parent organizations provide automatic membership in the TMA and the TMA functions as a committee of the parent association. In this case, the governing board of the parent organization provides final authority for decision making for the TMA.

Category 5. One TMA whose service area is citywide is required to provide services to all employers, residences and businesses within the city. In this case, the membership is defined as all those eligible to receive services by virtue of location within the city. This category might also include those members as some number of individuals who subscribe to services.

Thus, TMA memberships that include members of a parent organization can have memberships in the thousands, while TMAs whose boards of directors are the members may have less than ten members.

The number of members may also be closely tied to voting rights, dues category or other means of funding the TMA. For example, one TMA gave numerical figures for voting members and for public affiliates (non-voting) members. Many TMAs explained that they do not have formal memberships. Two TMAs responded that the question was not applicable. Some gave a split figure between the total number of members as well as the number of active members. One TMA provided membership figures for different grades of membership, such as full member, affiliate and supplemental. Another TMA gave membership figures based upon categories such as regular member, ex-officio and trade-out. Six TMAs gave numerical ranges as an answer. Ten TMAs gave memberships ranging from 4,000 to 24,000. Two TMAs were too new to categorize, and the others are categorized below.

Figure 5: Number of Members by Category_of Membership
\begin{tabular}{|l|c|cc|c|c|}
\hline Category & $\begin{array}{c}\text { Total \# of } \\
\text { TMAs }\end{array}$ & $\begin{array}{l}\text { Total } \\
\text { unknown } \\
\text { responses }\end{array}$ & Range & Mean & Median \\
\hline 1. Member companies & 32 & 2 & $6-4000$ & 59 & 33 \\
\hline 2. Members as board participants & 20 & 4 & $3-48$ & 18 & 15 \\
\hline 3. Members as property owners & 8 & 4 & $99-15,000$ & -- & -- \\
\hline 4. Joint memberships & 34 & 6 & $4-24,000$ & 729 & 28 \\
\hline 5. Members as service recipients & 1 & -- & -- & -- & -- \\
\hline
\end{tabular}


It was anticipated that by assigning the TMAs to different categories based on five member definitions, there would emerge some clear distinctions in the number of members. However, the distinctions are still not all that clear cut. All member categories have wide ranges in the number of members. The median figures for the number of members seem to show more realistic figures than the mean because the pools of numbers would contain far more on the smaller side, then just a few with very large numbers. In category 3 , the eight TMAs that have memberships within a business improvement district or community improvement district also indicated quite a range in the number of members, perhaps because the geographic size of the district as well as other land use characteristics can vary significantly from one district to another. Because only four of the eight TMAs responded with a specific figure, the mean and median did not seem to be useful to calculate. Perhaps what this exercise best illustrates is the great diversity of TMAs, even when comparing groups of TMAs with similar membership criteria. What appears most striking about the results is the large range in number of members for TMAs, even for the category where members are essentially the same as those serving on a governing board.

Member Recruitment Activities

9. How does your organization recruit members?

The question of member recruitment may not apply to some TMAs whose mission involves the specific relationship between a few particular entities, in which the solution to the transportation issue would not be addressed by expanding the involvement to include others.

The majority of responses appear to interpret the question as the number of member companies. Most TMAs that use mandatory participation, do so for only a portion of the membership. While the intent of the survey question regarded recruiting success, this does not apply to those whose members are so by virtue of location within a business improvement district and whose taxed property owners automatically become TMA members. For these TMAs, members gained and lost is more a reflection of change in economic activity within the service area. Respondents whose membership is defined by a community improvement district (CID) will answer the question not regarding recruiting members but encouraging use of available services.

Over 75 percent of the TMAs use some combination of two or more recruitment tactics. Figure 6 shows comparisons and changes in the use of recruitment methods by TMAs over the past ten years.

In 1993, 43 percent of all TMAs used some combination of recruitment tactics while in 2003, 75 percent of all TMAs used two or more recruitment tactics. A comparison indicates that the Executive Director continues to do the lion's share of member recruitment, even though this has 
Dage 1

$\square$ Page 2

$\square$ Page 3

$\square$ Page 4

$\square$ Page 5

1 Page 6

$\square$ Page 7

Page 8

$\square$ Page 9

$\triangle$ Page 10

$\square$ Page 11

Dage 12

$\square$ Page 13

$D$ Page 14

$\square$ Page 15

$\square$ Page 16

$\square$ Page 17

$\square$ Page 18

$\square$ Page 19

$\square$ Page 20

$\square$ Page 21

$\triangle$ Page 22

$\triangle$ Page 23

$\square$ Page 24

Page 25

$\triangle$ Page 26

Page 27

$\triangle$ Page 28

Page 29

Dage 30

$\square$ Page 31

$\square$ Page 32

Dage 33

$\triangle$ Page 34 \\ 2003 Transportation Management Association (TMA) Survey}

decreased a little over the last ten years. The real shift appears to be recruitment responsibility from the membership to the Board Chair. Out of the 97 possible responses, four survey participants did not respond to this question. Of the remaining 93, 20 TMAs use mandatory membership. One TMA did no recruiting and four others do not recruit because all property owners are members in the TMA defined as a municipal district in which members pay taxes.

While three TMAs indicated that they use all of the recruitment tactics listed, over 75 percent of the TMAs use some combination of two or more of the recruitment tactics. The frequency for each tactic is provided in Figure 6. For example, 69 percent of all TMAs who use recruitment tactics use contact from the Executive Director.

Figure 6: Comparison of Recruitment Tactics

\begin{tabular}{|l|l|l|}
\hline Recruitment Tactic & $\mathbf{1 9 9 3}$ & $\mathbf{2 0 0 3}$ \\
\hline Contact from Executive Director & $75 \%$ & $69 \%$ \\
\hline Peer-to-peer contact & $66 \%$ & $42 \%$ \\
\hline Contact from Board Chair & $25 \%$ & $52 \%$ \\
\hline Invitation to TMA-sponsored presentations & -- & $44 \%$ \\
\hline Brochure/packet of information & -- & $33 \%$ \\
\hline $\begin{array}{l}\text { Presentations by Board member or Executive } \\
\text { Director as business meeting }\end{array}$ & -- & $33 \%$ \\
\hline Cold calling to meet with the Executive Director & -- & $29 \%$ \\
\hline Mandatory membership & -- & $22 \%$ \\
\hline Other & -- & $12 \%$ \\
\hline Joint membership in parent organization & -- & $4 \%$ \\
\hline
\end{tabular}

Recruitment tactics listed under "other" included:

Website

Newsletter

Holiday shuttle

Program participation

Potential members contact us

Seasonal promotions/contests 
$\square$ page 1

$\square$ Page 2

$\square$ page 3

$\triangle$ Page 4

Page 5

7 Page 6

7 Page 7

Page 8

$D$ Page 9

$\checkmark$ Page 10

Page 11

Page 12

Page 13

Dage 14

Dage 15

Dage 16

Page 17

Dage 18

Page 19

Dage 20

$\square$ Page 21

$\square$ Page 22

Page 23

$\square$ Page 24

Page 25

7 Page 26

Page 27

Page 28

7 Page 29

Page 30

Page 31

Page 32

Page 33

Page 34
2003 Transportation Management Association (TMA) Survey

Most Successful Recruitment Activity

10. Which method for recruiting membership do you view as most successful?

Figure 7 indicates the collective vote of all TMAs regarding the most successful member recruitment tactics in 2003. Of the 97 possible respondents, three did not respond and one said the TMA was too new to know. Of the remaining 93 respondents, 14 respondents checked more than one. The vote is as follows below. For example 25 percent of all TMAs chose contact from the executive director as the most successful membership recruitment tactic. One TMA responded that he has not found any successful recruitment tactics. Best tactics listed under "other" included:

Municipal district that requires membership

Program participation

Work with city economic development office to bring in new property owners into municipal district

Contact from property manager vouching for TMA value

Advertisements in the newspaper

Figure 7: Most Successful Recruitment Tactic

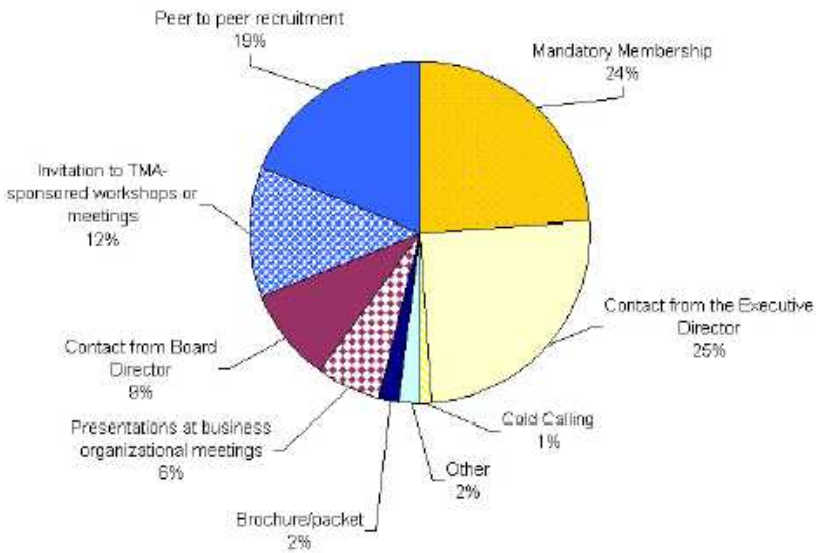

$2 \%$ 
Figure 8 shows a comparison of attitudes regarding the most successful recruitment practices between 1998 and 2003. While TMAs rated contact from executive director and peer-to-peer (member to member) recruitment among the most successful tactics, we find that use of these tactics both decreased from 10 years ago. The decreases might be explained by expanding the use of other tactics and that these tactics are used in combination. While only $9 \%$ think that contact from a board director is the most successful tactic, the use of this tactic has increased from $25 \%$ to $52 \%$. This may indicate more involvement by directors and less involvement by members. It is also understood that what may be most successful for one TMA may not work as well for another.

Page 9

Page 10

Page 11

$\square$ Page 12

$\square$ Page 13

$\square$ Page 14

$\square$ Page 15

$\square$ Page 16

$\square$ Page 17

$\square$ Page 18

$\square$ Page 19

$\square$ Page 20

$\square$ Page 21

$\square$ Page 22

$\square$ Page 23

$\square$ Page 24

$\square$ Page 25

$\square$ Page 26

Dage 27

$\square$ Page 28

$\square$ Page 29

$\square$ Page 30

$\square$ page 31

$\square$ page 32

$\square$ page 33

$\square$ page 34

Figure 8: Comparisons of Most Success ful Recruiting Method

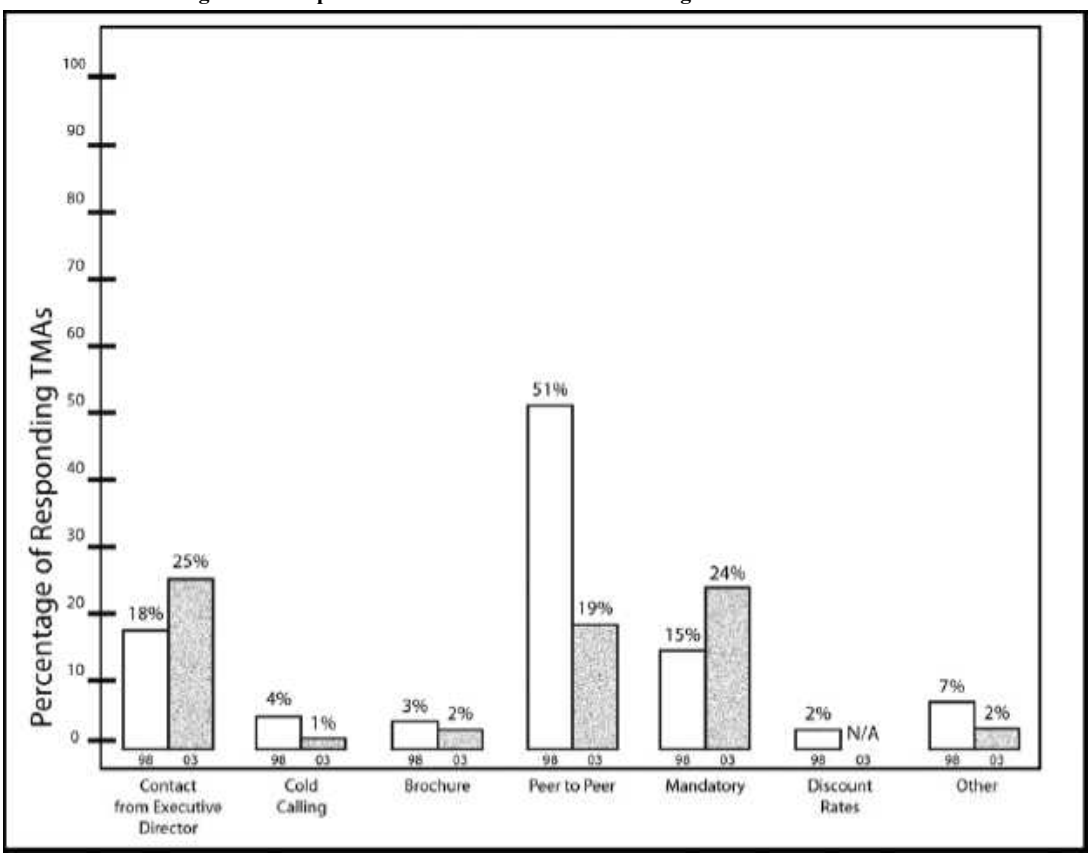


Page 1

$\square$ Page 2

$\triangle$ Page 3

Page 4

Page 5

$\square$ Page 6

$\square$ Page 7

$D$ page 8

$\triangle$ Page 9

$\triangle$ Page 10

Page 11

Page 12

Page 13

Page 14

Dage 15

Dage 16

Page 17

Dage 18

$\square$ Page 19

Dage 20

Page 21

$\square$ Page 22

Page 23

$\square$ Page 24

Page 25

$D$ Page 26

Page 27

Page 28

Page 29

Page 30

Page 31

Page 32

Page 33

$\square$ Page 34
2003 Transportation Management Association (TMA) Survey

\section{Members Recruited/Lost}

11. Approximately how many new members did you recruit/lose last year?

The majority of responses appeared to interpret the question as the number of member companies gained or lost. But again, the data indicate that "member" has a differing definition from one TMA to another. In 1993, it was reported that 37 percent of all TMAs had no turnover in the past year with an average turnover rate of 6 percent. In 2003, TMAs reported member gains ranging from $0-1,000$ with a median gain of 3, and member losses ranging from $0-150$ with a median loss of 2 members. Some survey participants might have interpreted the question as presupposing that TMAs want to expand in membership. The survey results show that not all of them do. Out of the 97 possible respondents, there were nine that did not respond, five "not applicable" and two responses with question marks. Three more responded by giving a numerical range and five more respondents provided answers greater than 450 .

Percentage of Entire Potential Member Base

12. Out of the entire potential membership base located within your TMA service area, what percentage of these is actually represented as members on the TMA? Also include within this percentage, all employers who lease office space from property owners who are members on the $T M A$.

This was a new question that replaced the 1998 survey question, "Estimate what percentage of area employers is represented on the TMA." Out of 96 potential respondents, 12 did not answer, three put question marks, and eight answered "non-applicable". Most answering "nonapplicable" were CIDs in which membership is required. Of the 73 remaining, the distribution of answers was spread evenly from zero to 100 percent, with some thinning in the middle. Fiftythree percent of those responding indicate 30 percent or less. Forty percent of those responding indicate 60 percent or more. Nine TMAs indicated 100 percent participation. Some of these nine TMAs were CIDs, while others may have first started with a membership base and the service area was defined according to its current members. 
Page 1

$\square$ Page 2

$\square$ Page 3

$\triangle$ Page 4

$\square$ Page 5

$\square$ Page 6

$\triangle$ Page 7

Page 8

$\triangle$ Page 9

7 Page 10

Page 11

Dage 12

Page 13

Dage 14

Page 15

Dage 16

Page 17

Dage 18

$\square$ Page 19

Page 20

7 Page 21

Page 22

Page 23

$\square$ Page 24

Page 25

7 Page 26

Page 27

Page 28

Page 29

Page 30

Page 31

Page 32

Page 33

Page 34
2003 Transportation Management Association (TMA) Survey

\section{TMA Services}

Magnitude of Travel Markets

14. Approximately how many of each of the following types of travel target markets does the TMA currently serve?

This was a new question in the 2003 TMA Survey and replaced the previous question of "Approximately how many commuters does your TMA represent?" The question attempted to enable a TMA to distinguish between its membership and the overall markets to which it offers services. Membership, as implicitly defined by the survey, represents the number of entities formally or actively involved in the TMA. Travel markets represent the number of individuals that constitute the potential customer base. The question also was intended to find out the extent to which TMAs provide services aimed at reducing other forms of travel besides traditional commuter travel. Out of the 97 total possible responses, 11 TMAs did not respond to the question. Thirteen respondents answered by giving the percentages for each travel market they serve rather than a numerical answer. Of these thirteen, ten respondents replied that 100 percent of their travel markets are commuters. Twelve more respondents placed check marks rather than numerals, simply indicating which travel markets their TMA served. In 1993, the average TMA covered an area that contained an average of 45,800 commuters. In 2003, that average increased slightly to 49,100 commuters. Figure 9 summarizes the magnitude of the potential customer base of TMAs by travel market.

All but three TMAs indicated that their TMAs serve commuters. Fifty-six out of the 97 total respondents, or 58 percent of all respondents, indicated that their TMAs also serve travel markets in addition to or other than commuters. These include 45 percent of the 97 total respondents indicating they serve students, 40 percent serve residents, 29 percent serve visitors, and 5 percent serve other travel markets. Examples of "other" given were hospital-related traffic, airport passengers and meet/greeters and festivals or special event traffic. There were six TMAs that indicated they serve only travel markets other than commuters. The magnitude of visitor travel markets served by TMAs ranged from 500 to 8,000,000 although it would appear that several visitor totals given are annual rather than daily figures.

Figure 9: Magnitude of Potential Customer Base of TMAs

\begin{tabular}{||l|l|ll||}
\hline \hline TRAVEL MARKET & RANGE & MEAN & MEDIAN \\
\hline COMMUTERS & $300-400,000$ & 49,100 & 20,000 \\
\hline STUDENTS & $200-100,000$ & 16,500 & 10,000 \\
\hline RESIDENTS & $1000-300,000$ & 46,100 & 22,500 \\
\hline VISITORS & $500-8,000,000$ & $1,130,500$ & 47,500 \\
\hline
\end{tabular}

- 
$\square$ page 1

$\square$ Page 2

Page 3

$\square$ Page 4

Page 5

$\square$ Page 6

7 Page 7

Page 8

$D$ Page 9

$\checkmark$ Page 10

Page 11

Page 12

Page 13

Dage 14

Dage 15

Dage 16

Page 17

Dage 18

Page 19

Dage 20

Page 21

$\square$ Page 22

$D$ Page 23

$\square$ Page 24

Page 25

$D$ Page 26

Page 27

Page 28

7 Page 29

$\checkmark$ Page 30

Page 31

Page 32

Page 33

$\square$ Page 34
2003 Transportation Management Association (TMA) Survey

Geographic Scope of Service Area

15. What is the geographic scope of the TMA's service area? Check only one.

Ninety-six out of 97 respondents provided an answer to this question. Figure 10 illustrates the variation in responses. Regional (multijurisdictional) TMAs comprised 19 percent of all TMAs, citywide (one jurisdiction) comprised six percent of all TMAs, and corridor TMAs comprised 21 percent of all TMAs. Another 15 percent were central business district TMAs. Suburban (fringe activity center) TMAs comprised 11 percent of all TMAs. Specialized activity centers comprised 14 percent of all TMAs. Specialized activity centers were defined within the survey instrument as large development complexes relating to universities, tourist attractions, hospitals airports, or an industry. "Other" types of TMAs comprised the final 14 percent of all TMAs.

Figure 10: Geographic Scope of TMA Service Area

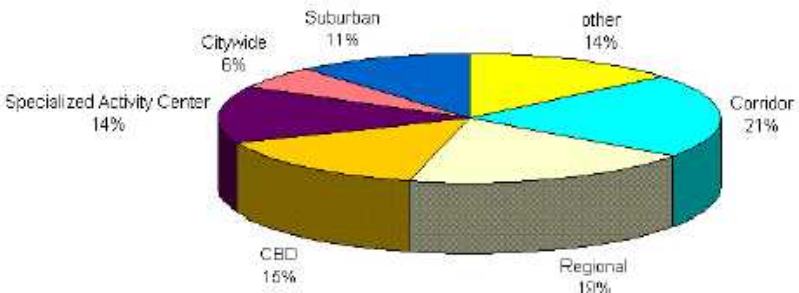

The 2003 TMA Survey offered two additional answer options for the description of the scope of the TMA service area. It shows that a significant portion, 28 percent of TMAs today do not fit the traditional service areas of ten years ago, as shown in Figure 11. 
Figure 11: Comparison_of TMA Scope of Service Area

\begin{tabular}{|ll|l|}
\hline Scope of Se rvice Area & $\mathbf{1 9 9 3}$ & $\mathbf{2 0 0 3}$ \\
\hline Regional & $26 \%$ & $19 \%$ \\
\hline Suburban & $22 \%$ & $11 \%$ \\
\hline Corridor & $20 \%$ & $21 \%$ \\
\hline Central Business District & $12 \%$ & $15 \%$ \\
\hline Citywide & $10 \%$ & $6 \%$ \\
\hline Specialized Activity Center & -- & $14 \%$ \\
\hline Other & -- & $14 \%$ \\
\hline
\end{tabular}

In 1993, the survey analyst suggested a trend of TMAs increasing their geographic scope of influence. However, while TMAs in 2003 do not appear to be continuing to expand geographic influence as the above numbers suggest, they are finding it useful to more closely specify that geography as represented by the 28 percent that identify themselves as either specialized activity center or "other." Other types of TMAs included countywide, an industrial park, a rural TMA, a single employer, half a city, a master planned community, an area larger than a CBD but smaller than citywide, a bi-county low density research and development park, a national park and a statewide TMA. While a few of these other types appear to fall within some of the traditional categories, no recategorizing of TMAs was done because it is believed that the TMA knows best how to accurately categorize its geographic scope.

\section{Services Offered}

16. "Check which of the following services your TMA offers, including contract services from a third party."

In 1993, advocacy and promotion were the most common TMA activities. In 2003, the most frequently offered services were promotional materials/newsletters, rideshare matching, promotional events, guaranteed ride home and regional/local advocacy. The least frequently offered services included parking services and management, which was initially measured in 1993 as a service type not frequently offered and it is continuing to decrease over time. Carsharing was also among the least frequently offered services. This was not measured in previous surveys and is considered to be among the more recent innovations in service provision. Direct shuttle service operation was also among the least offered services. Beginning in 2003, the answer option, "Direct shuttle service operation", was provided to distinguish from the more general "Shuttle/local transit provision." In 2003, 71 percent of all responding TMAs did not offer direct shuttle service operation, which means 29 percent do. It is remarkable that close to one third of all responding TMAs provide direct shuttle service operation. Figure 12 below 
page index I bookmark

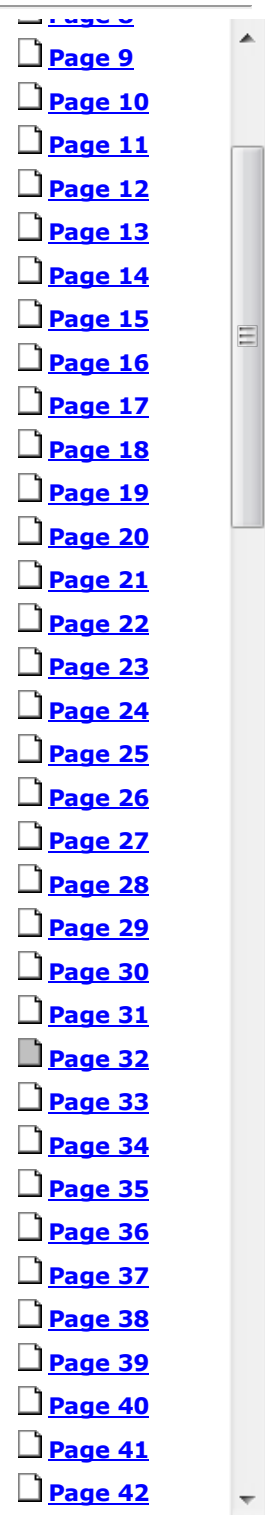

shows the percentage of all responding TMAs that offer each service for the years 1993, 1998 and 2003. Services listed under "other", which were offered to members in 2003 include:

Visitor services

Relocation assistance

Electric Vehicle promotion

Construction/traffic advisories

Government reporting/compliance

Alternative fuel infrastructure development

Walking program

Cycling safety workshops

Active living program

Pedestrian amenity review

Livable community camps

Spanish translated information 


\section{Transportation Management Association (TMA) Survey}

Figure 12: Percentage of Responding TMAs That Offer Service Comparisons With Data From 1993 and 1998 Surveys*

\begin{tabular}{|c|c|c|c|c|c|c|c|c|c|}
\hline \multirow[t]{2}{*}{ Service } & \multirow{2}{*}{$\begin{array}{l}\begin{array}{l}\text { Provided } \\
\text { to } \\
\text { members }\end{array} \\
1993\end{array}$} & \multicolumn{2}{|c|}{$\begin{array}{l}\text { Provided to } \\
\text { members } \\
\text { only }\end{array}$} & \multicolumn{2}{|c|}{$\begin{array}{l}\text { Provided to } \\
\text { non-members } \\
\text { only }\end{array}$} & \multicolumn{2}{|c|}{$\begin{array}{l}\text { Provided to } \\
\text { members and } \\
\text { non-members }\end{array}$} & \multicolumn{2}{|c|}{$\begin{array}{l}\text { Provided to } \\
\text { non-membel } \\
\text { at a higher ri }\end{array}$} \\
\hline & & 1998 & 2003 & 1998 & 2003 & 1998 & 2003 & 1998 & 200 \\
\hline ETC training & 61 & 499 & 34 & 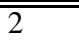 & 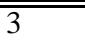 & 12 & 15 & 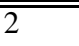 & 1 \\
\hline Rideshare matching & 73 & 33 & 37 & 5 & 5 & 45 & 43 & 0 & 1 \\
\hline Rideshare promotion & -- & 55 & -- & 5 & -- & 33 & -- & 1 & -- \\
\hline Telecommuting assistance & -- & -- & 31 & -- & 2 & -- & 18 & -- & 2 \\
\hline Transit pass sales & 39 & -- & -- & -- & -- & -- & -- & -- & -- \\
\hline Subsidized transit passes & -- & 18 & 35 & 5 & 2 & 9 & 14 & 0 & 2 \\
\hline Direct rideshare incentives & -- & -- & 39 & -- & 1 & -- & 13 & -- & 2 \\
\hline Shuttle/local transit provision & 31 & 16 & 27 & 4 & 3 & 15 & 23 & 5 & 1 \\
\hline Direct shuttle service operation & -- & -- & 15 & -- & 1 & -- & 11 & -- & 2 \\
\hline Guaranteed Ride Home & 67 & 56 & 51 & 5 & 2 & 13 & 22 & 2 & 3 \\
\hline Vanpool Services & 78 & 33 & 35 & 4 & 3 & 21 & 28 & 0 & 0 \\
\hline Vanpool subsidy program & 24 & 26 & 36 & 4 & 2 & 12 & 16 & 0 & 0 \\
\hline Regional/Local advocacy & 96 & 57 & 41 & 4 & 1 & 28 & 32 & 1 & 0 \\
\hline Site design assistance & -- & 37 & 21 & 4 & 0 & 6 & 15 & 4 & 1 \\
\hline Trip reduction plan preparation & 69 & 41 & 38 & 2 & 0 & 9 & 20 & 9 & 3 \\
\hline Parking service provision & -- & 23 & 18 & 4 & 0 & 2 & 9 & 2 & 0 \\
\hline Parking pricing and/or management 41 & & 22 & 15 & 4 & 0 & 2 & 9 & 2 & 1 \\
\hline Promotional materials/newsletters & 84 & 43 & 47 & 4 & 2 & 41 & 36 & 1 & 3 \\
\hline Promotional events & 90 & 55 & 44 & 2 & 2 & 32 & 34 & 2 & 3 \\
\hline Tax benefit program assistance & -- & -- & 38 & -- & 3 & -- & 22 & -- & 1 \\
\hline Carshare program & -- & -- & 13 & -- & 1 & -- & 11 & -- & 0 \\
\hline Bicycle program & -- & -- & 32 & -- & 2 & -- & 21 & -- & 1 \\
\hline Other & 29 & -- & 23 & -- & 0 & -- & 6 & -- & 2 \\
\hline Develop survey & 67 & -- & -- & -- & -- & -- & -- & -- & -- \\
\hline
\end{tabular}

* Totals across rows may not equal 100 percent due to rounding error. 


\section{Transportation Management Association (TMA) Survey}

Since 1993, a growing proportion of TMAs are now offering vanpool subsidies, transit I subsidies, guaranteed ride home, rideshare matching, and shuttle/local transit service, as shown in Figure 13. Since 1993, a decreasing proportion of TMAs are now offering employee transportation coordinator (ETC) training; regional/local advocacy; site design assistal parking services, pricing and/or management; trip reduction plan preparation; and promotional events, as shown in Figure 14. The level of involvement between 1993 and 2003 has s roughly the same for offering promotional materials. Vanpool services have fluctuated from 78 percent of all responding TMAs offering them in 1993, down to 57 percent in 1998, then back u to 66 percent in 2003.

Figure 13: Services Increasingly Offered by TMAs

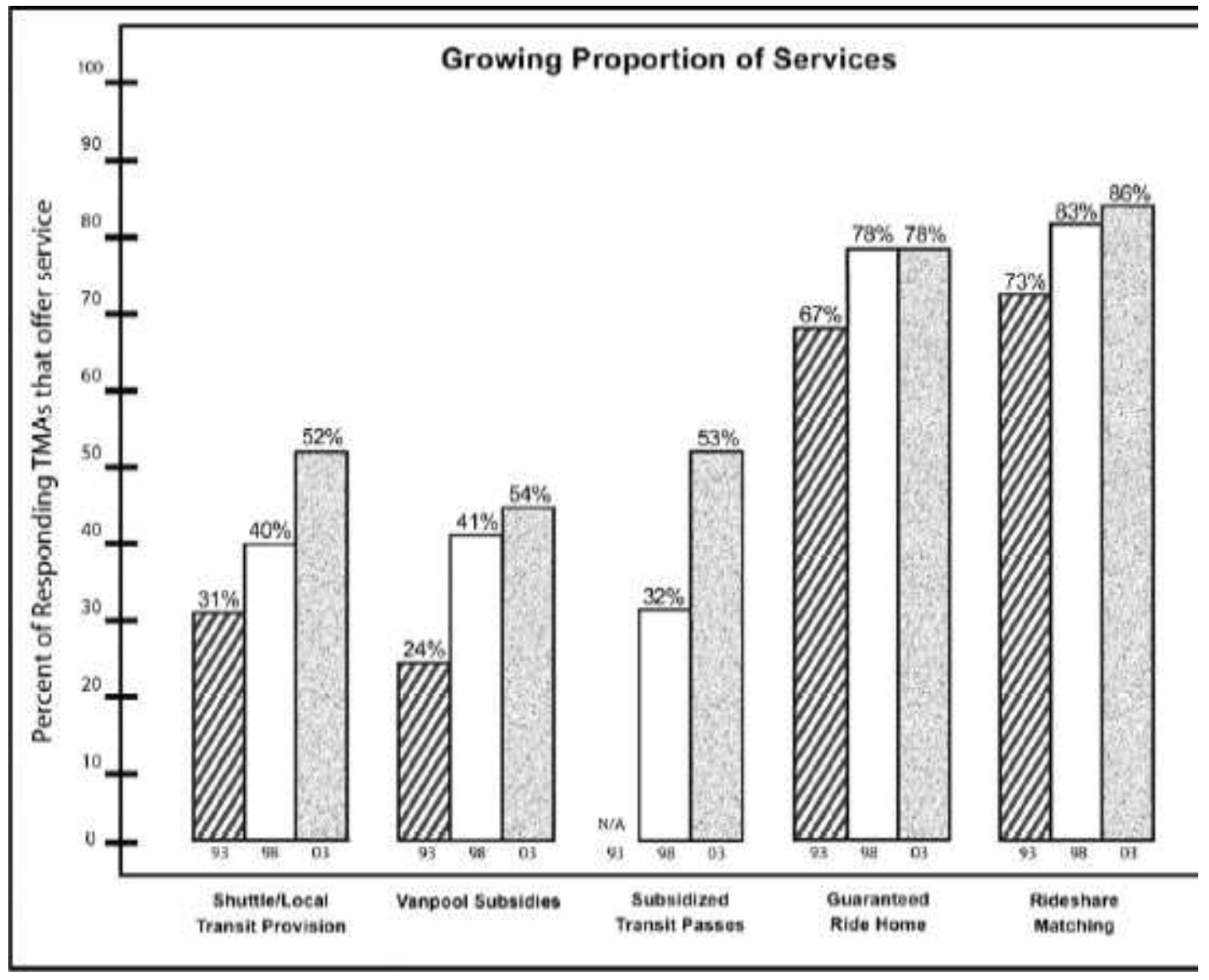

It is possible that these decreases can be explained by what appears to be an expansion in the sheer variety of services offered by TMAs. TMAs appear to be growing more distinct in their service provision, tailoring services to the needs of their travel markets. As a result, fe TMAs are offering the more traditional services. 


\section{Transportation Management Association (TMA) Survey}

Figure 14: Services Offered Less by TMAs

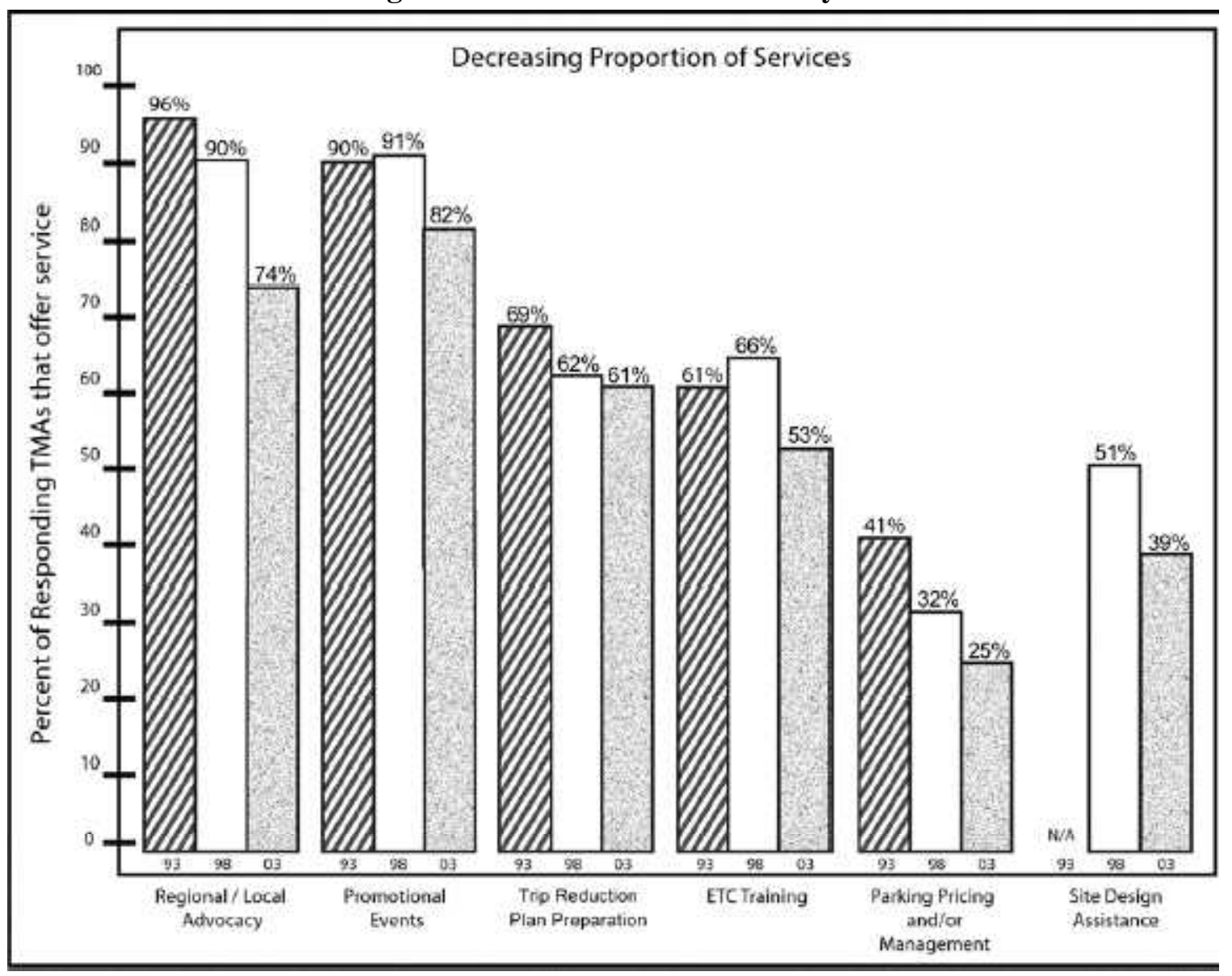

\section{Program Evaluation Activities}

17. Does the TMA conduct any of the following types of program or service evaluation or assessment activities? Please check all that apply.

Seventy-nine TMAs conduct program/service evaluations and the distribution of methods utilized are shown in Figure 15 below. 


\section{Transportation Management Association (TMA) Survey}

Figure 15: Program/Service Evaluations

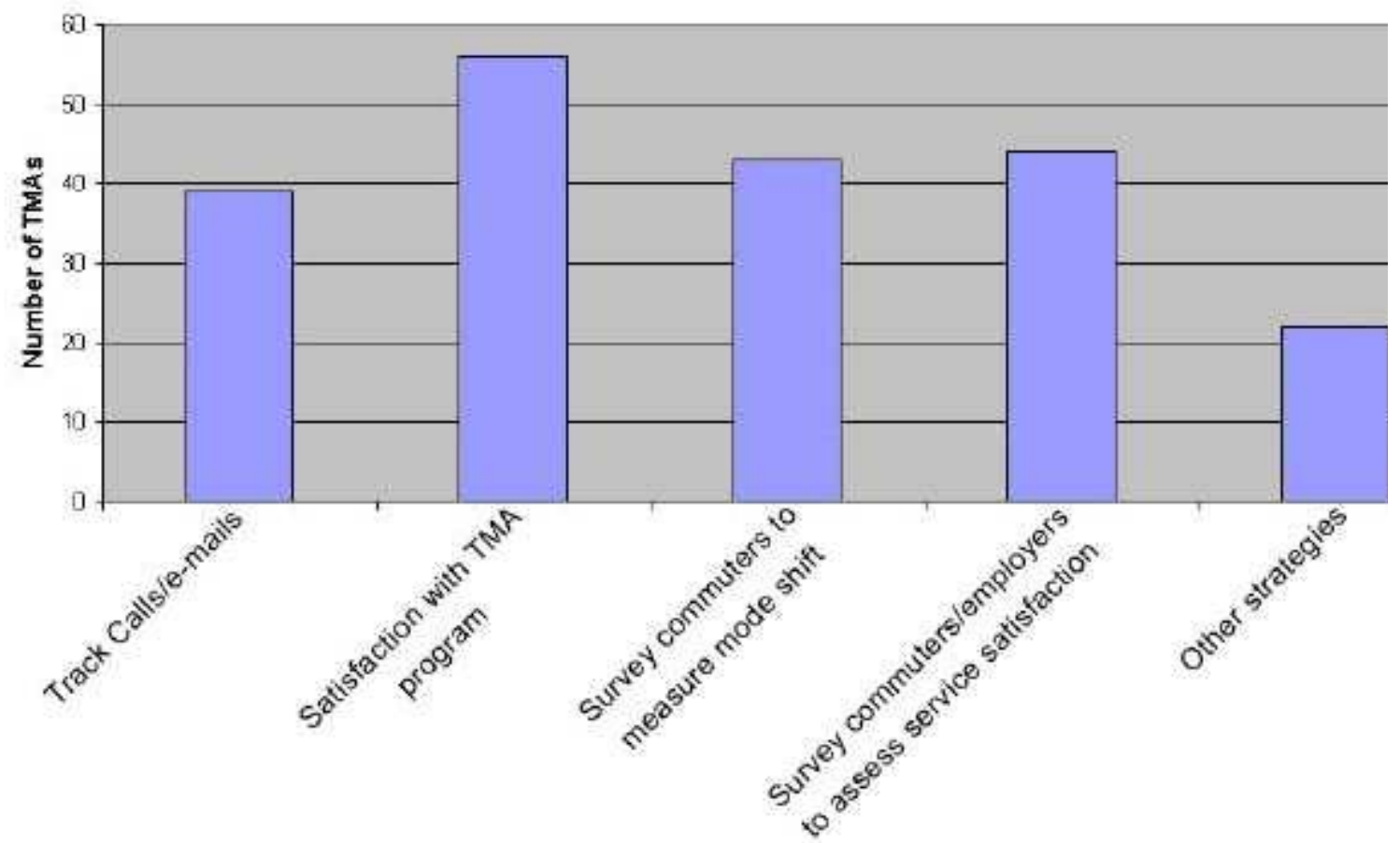

In 1993, less than 50 percent of TMAs conducted program evaluations. In 2003, 81 percent had conducted program evaluations, including 55 percent that surveyed members, 43 percent surveyed commuters, employers and members about services, 42 percent that surve commuters to assess mode shift, 39 percent that tracked calls and emails received in response to marketing and outreach activities, and 22 percent that conducted other types of evaluatio activities.

\section{Frequency of Evaluation}

18. How often are these evaluations or assessments conducted? Check only one.

This was a new question in the 2003 TMA Survey. Six TMAs stated they were too new to have established their timelines for evaluation. Figure 16 shows the distribution of the frequency of evaluations for the remaining TMAs. 
Figure 16: Frequency of Evaluations or Assessments

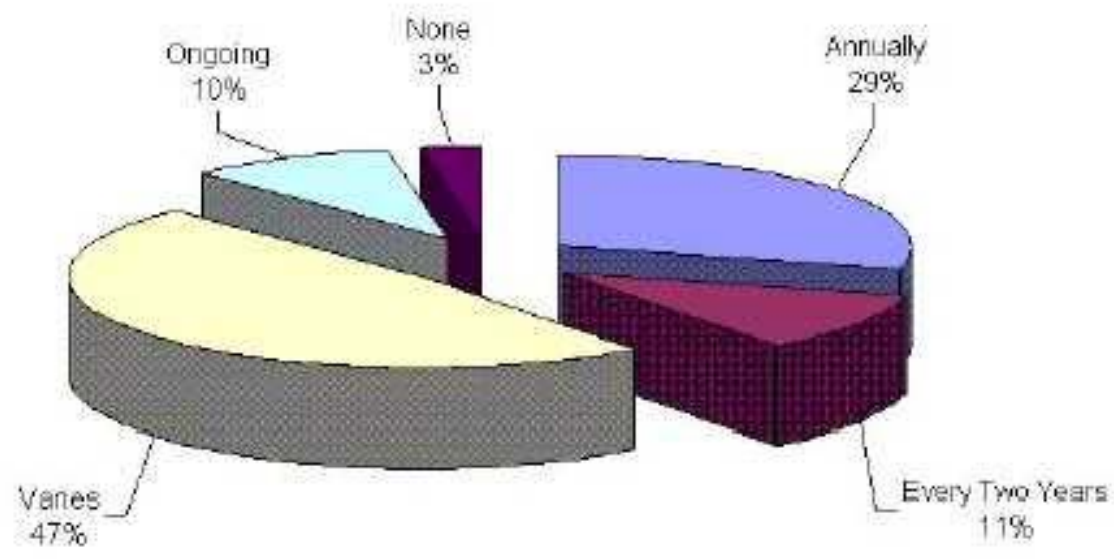




\section{Transportation Management Association (TMA) Survey}

\section{Personnel and Policies}

\section{Number of Staff}

20. Please list the number of persons employed by your organization.

A comparison of the numbers of staff employed by TMAs in 1993 and in 2003 indicated that TMAs today have more paid personnel and rely less on volunteers. Figure 17 illustrate comparison of the percentage of TMAs with various staffing levels between the years 1993 and 2003. The 2003 values combine both full-time and part-time staff in order to compare with the data for 1993. The 2003 values include both permanent and contract staff.

Figure 17: Percentage of TMAs with Numbers of Staff (Full-time and part-time combine

\begin{tabular}{|l|l|l}
\hline Number of staff & $\mathbf{1 9 9 3}$ & $\mathbf{2 0 0 3}$ \\
\hline No staff & -- & $5 \%$ \\
\hline Volunteers & $28 \%$ & $4 \%$ \\
\hline 1 person & $43 \%$ & $21 \%$ \\
\hline 2 persons & $8 \%$ & $18 \%$ \\
\hline 3 persons & $12 \%$ & $18 \%$ \\
\hline More than 3 persons & $9 \%$ & $32 \%$ \\
\hline Not known & -- & $2 \%$ \\
\hline
\end{tabular}

In 1993, 72 percent of TMAs employed contract staff and 39 percent of all TMAs employed ont part-time person. In 1993, the mean number of staff for all TMAs was 1.7 persons. In 2003, ou of the 97 possible responses, 82 percent employed full time staff, 45 percent employed part-tim staff, 8 percent employed volunteers and 16 percent employed contract staff to administer the TMA. The number of contract staff ranged from one to six with a median of one. The number of full time staff ranged from one to 20 with a median of two. The number of part time staff ranged from one to four with a median of one. The number of contract staff ranged from one to six with a median of one. The most common staff combination in 2003 was a full time executiv director with one other person who is either full time or part time.

Five TMAs indicated that they have neither paid staff nor volunteer staff. In these cases, there may be a facilitator from a parent organization. In five additional cases, the TMAs indicated they have from 50 to 350 full time employees. These cases appear to be the number of full time staff of a parent organization. 


\section{Transportation Management Association (TMA) Survey}

\section{Vendor Hiring}

21. Does your TMA hire consultants or vendors for the direct provision of services?

In 1993, 25\% of TMAs contracted for management services, including TMAs with both large and small budgets. Young TMAs tended to contract out more frequently for day-to-day management services than TMAs older than two years. In 2003, 59 percent of TMAs hired consultants or vendors for the direct provision of services.

\section{Services Contracted Out}

22. If yes, which services are contracted out? Check all that apply.

Types of services contracted out in 1993 included accounting, legal, bus service, grant design, and newsletter design. In later surveys the answer options changed, as shown in Figure 18. In 2003, $16 \%$ of all TMAs contracted out for staff and 59\% of TMAs contracted out for services, as compared to $47 \%$ in 1998. 


\section{Transportation Management Association (TMA) Survey}

Figure 18: TMA Vendor Hiring

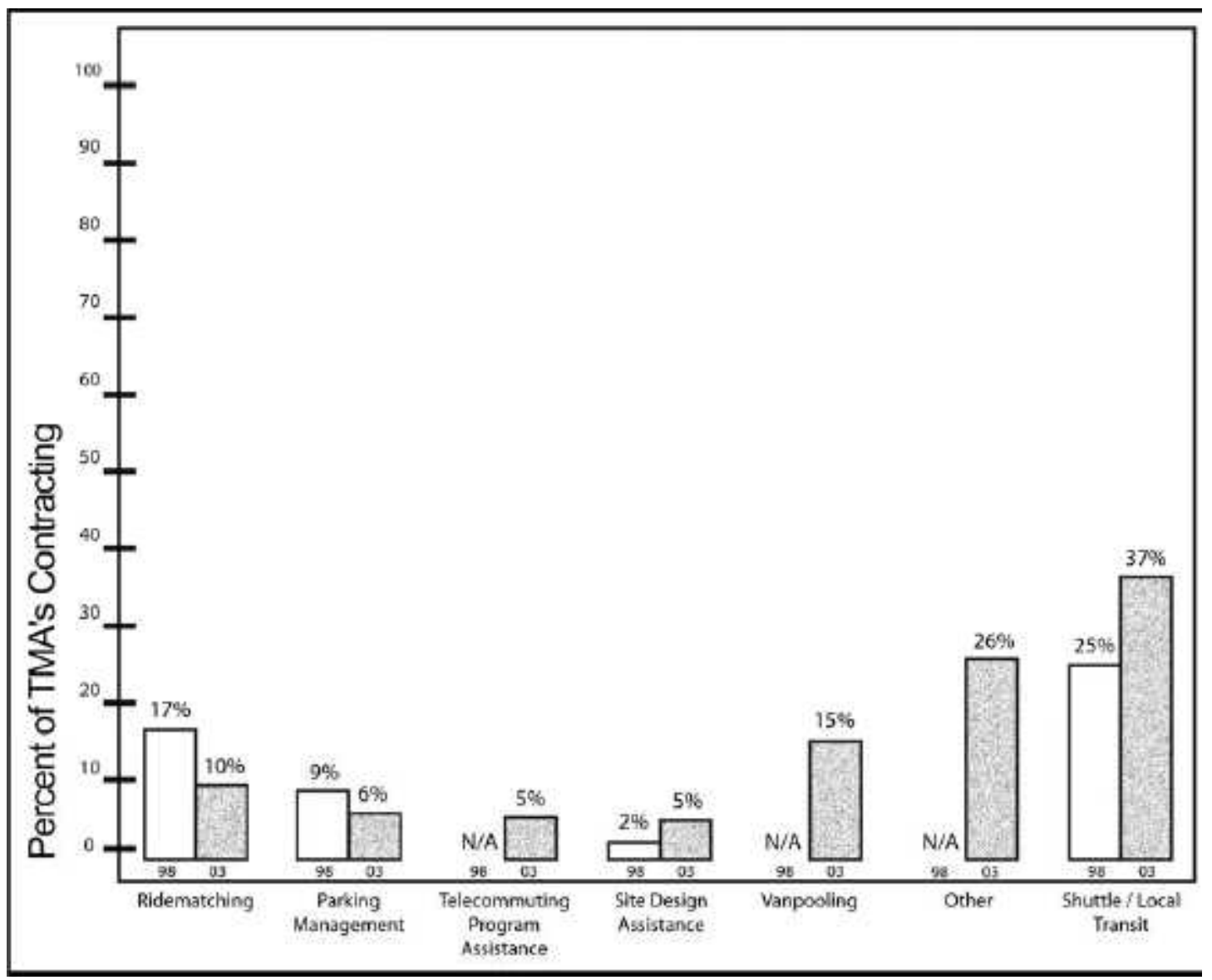

“Other” services contracted out in 2003 included marketing, route planning, grant adminis guaranteed ride home, studies/surveys, graphics, flexcar, fleet maintenance, website desig] information booths. Figure 19 shows an upward trend in TMAs contracting out $\mathrm{m}$. services, from 25\% in 1993 to 59\% in 2003 and a downward trend in contracting out for T staffing. Perhaps this reflects the understanding that generally small TMA staffs function if they concentrate on what they do best and not attempt to do everything themselves as th menus of services expand. 


\section{Transportation Management Association (TMA) Survey}

Figure 19: Comparison of Services Contracted

\begin{tabular}{|l|l|l|}
\hline & Contract out for TMA staff & $\begin{array}{l}\text { Contract out for consulting, } \\
\text { customer services }\end{array}$ \\
\hline 1993 & $72 \%$ & $25 \%$ \\
\hline 1998 & -- & $47 \%$ \\
\hline 2003 & $16 \%$ & $59 \%$ \\
\hline
\end{tabular}

\section{Executive Director Professional Background}

23. What is the professional background of the TMA's executive director? Place a " 1 " for primary experience, " 2 " for secondary experience, "3" for tertiary experience.

In 1993, the average Executive Director had a transportation background and was paid \$4: annually. The executive director background (did not specify educational, professic degree) in 1993 was listed as 53\% transportation, 53\% marketing, 43\% administrat: planning, and 28\% non-profit management.

By comparison, in 2003, the most frequently cited primary professional experience marketing (30\%), followed by transportation planning (24\%), then non-profit/as management (23\%). The most frequently cited secondary experience was transporti operations tied with planning (15\%), followed by marketing (14\%). The most frequently tertiary experience was non-profit/association management (13\%), followed by trans] planning tied with engineering (9\%). This indicates that TMA executive directors generally similar backgrounds to those in 1993, in addition to other backgrounds, s engineering, administration, government, public relations, sales and finance.

\section{Executive Director Educational Background}

24. What is the educational background of your TMA's Executive Director? Place a "1" for major degree, "2" for minor degree.

The educational background of TMA executive directors varied widely. Many resF checked more than one degree type as a major degree. Of the survey selections available, "other" selection was the most encountered at 46\%, while "other" was selected by 19 perc TMA directors in 1998. Other degree majors included foreign language, sciences, psycho communications, journalism and history, just to name a few. 


\section{Transportation Management Association (TMA) Survey}

Figure 20: TMA Executive Director Educational Background

\begin{tabular}{|l|c|c|}
\hline Type degree & Major degree & Minor degree \\
\hline Social Science & $15 \%$ & $7 \%$ \\
\hline Marketing & $12 \%$ & $2 \%$ \\
\hline Planning & $12 \%$ & $1 \%$ \\
\hline Administration & $12 \%$ & $7 \%$ \\
\hline Public Relations & $8 \%$ & $2 \%$ \\
\hline Transportation Planner & $7 \%$ & $4 \%$ \\
\hline Public Management & $4 \%$ & $0 \%$ \\
\hline Transportation Engineer & $3 \%$ & $0 \%$ \\
\hline Finance & $2 \%$ & $0 \%$ \\
\hline Sales & $1 \%$ & $1 \%$ \\
\hline Non-profit management & $0 \%$ & $2 \%$ \\
\hline
\end{tabular}

\section{Executive Director Degrees Earned}

25. Which degrees has your TMA Executive Director obtained? Check all that apply.

Of the possible 97 TMAs, 91 TMAs responded, in which the highest degree earned by 53 perce of TMA directors was a bachelors degree, for 41 percent, a masters degree, for 1 percent, an associate degree and for 3 percent, a high school diploma only. Two TMAs declined to supply the level of education achieved. Of those having earned masters degrees, 22 percent earned a degree in public policy, planning, public administration or non-profit management; 7 percent earned a master of business administration, and the remaining 12 percent earned other masters degrees. Examples included architecture, communications and history.

\section{Executive Director Salary Range}

26a. Check the salary range that most accurately reflects the salary of the Executive Director and other key staff members.

In 1993, the TMA executive director's annual mean salary was $\$ 42,500$. In 2003 , the mean salary was $\$ 62,000$. Out of 97 total respondents, 13 gave no answer and two more TN supplied salaries for part-time positions only. These were given as $>\$ 30,000$ for a "half-time" person and within the $\$ 60-70,000$ range for a "part-time” person. For the remaining 82 respondents, the spread of salaries was shaped like a bell curve, as illustrated in Figure 21, with the median range earned by executive directors in the $\$ 60-70,000$ range and the mean salary as approximately $\$ 62,000$. This compares to a median salary in 1998 of between $\$ 40-49,000$ and 


\section{Transportation Management Association (TMA) Survey}

mean salary of $\$ 42,500$ in 1993. No TMA executive director indicated earning less tha $\$ 20,000$. Five TMA directors indicated earning more than $\$ 100,000$.

Figure 21: TMA Executive Director Salary

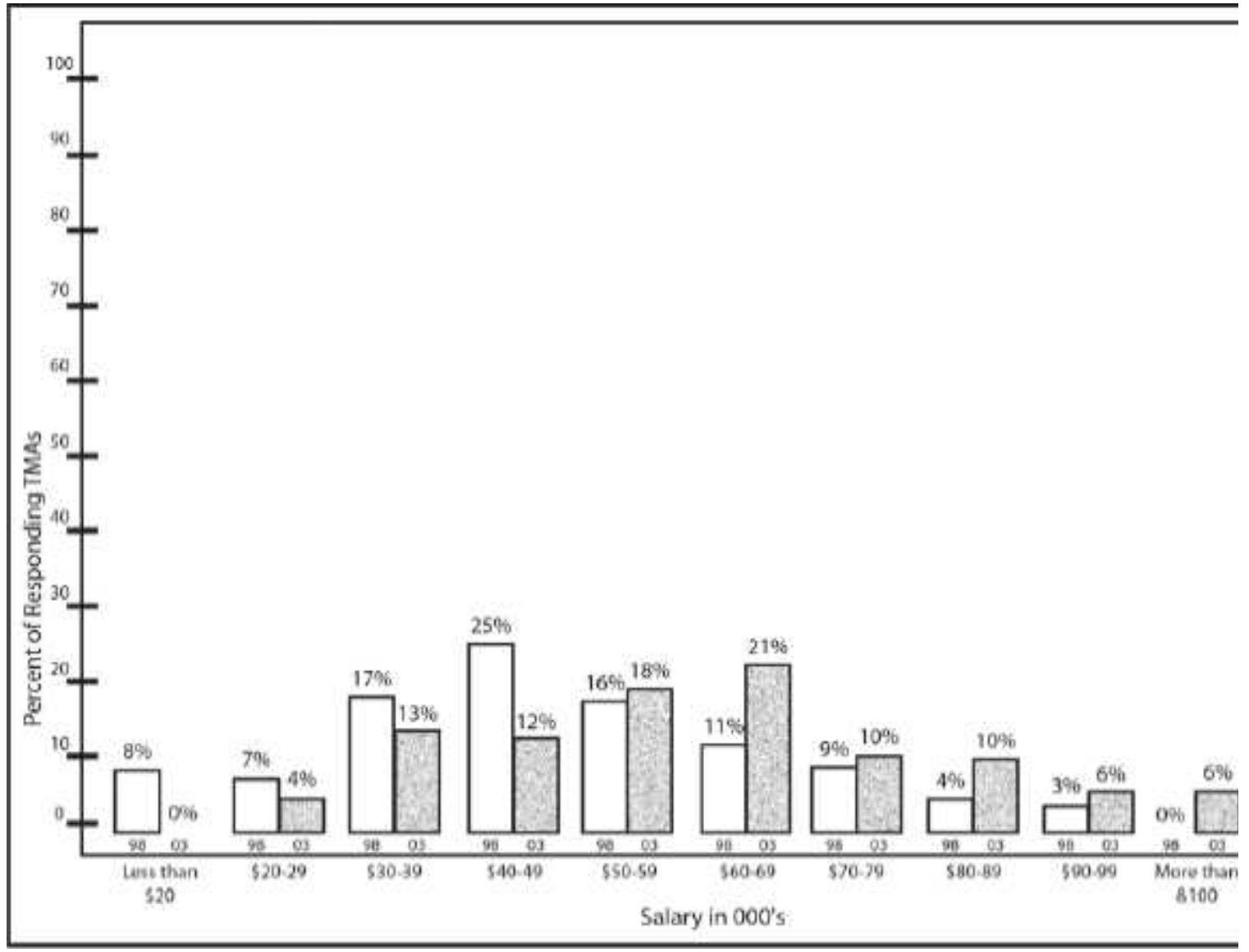

\section{Executive Director Years at TMA}

26b. Number of years with your TMA, cumulative all positions.

A total of 85 responses were provided regarding the number of years of experience that executive director has served with the TMA. The number of years ranged from 5 weeks to 22.5 years. The average number of years with the TMA was 5.1 years and the median number of years was 4 years. There were 47 respondents with 5 years or less and 16 respondents with 10 years or more experience with the TMA. 


\section{Transportation Management Association (TMA) Survey}

\section{Executive Director Years in TDM}

26c. Number of years in TDM.

There were 84 responses ranging from 8 months to 25 years. The median number of years TDM for an executive director was 7 years and the average was 8.3 years.

\section{TMA Staff Benefits}

27. Check any of the following benefits that are available for the TMA staff. Check al apply.

Out of the 97 total respondents, 20 respondents left the answer to this question either blan] wrote "nonapplicable" or "none". Of the remaining 77 respondents, the percentage that offer various benefits is as follows in Figure 22 below. Benefits listed under include: pre-tax parking, pre-tax transit, a retirement benefit other than those listed in the 1 a health insurance stipend, an IRA contribution, flextime, a health club membershif annual pass to a theme park. Generally, more types of insurance coverage have $b$ available to TMA staff over the years. It also appears that more TMAs are offering a grea variety of benefits. While the medical insurance benefit appears to have dropped since 19 is inconclusive, due to a flaw in the survey formatting, in which the medical insurance ans option may have been obscured. As a result, we know that at least 57 percent of all TMA: medical insurance. There does appear to be significant growth in offering retirement bene 


\section{Transportation Management Association (TMA) Survey}

Figure 22: Benefits Provided to TMA Staff

\begin{tabular}{|l|ll|l}
\hline \multirow{2}{*}{ Benefit } & \multicolumn{4}{l}{ Percentage of.TMAs that Offer } \\
\cline { 2 - 4 } & $\mathbf{2 0 0 3}$ & $\mathbf{1 9 9 8}$ & $\mathbf{1 9 9 3}$ \\
\hline Paid holidays & 91 & 70 & 75 \\
\hline Seminars & 77 & 59 & 73 \\
\hline Professional membership dues & 75 & 59 & 55 \\
\hline Free parking & 61 & 37 & 57 \\
\hline Medical insurance & 57 & 57 & 63 \\
\hline Dental or vision insurance & 56 & 43 & - \\
\hline Life insurance & 47 & 33 & 31 \\
\hline Subsidized transit passes & 44 & 22 & 14 \\
\hline Maternity/family leave & 40 & 15 & 18 \\
\hline Disability insurance & 39 & 26 & 35 \\
\hline 401(k) retirement & 38 & $23^{*}$ & $10^{*}$ \\
\hline Incentive or cash bonus system & 25 & 12 & - \\
\hline Section 125 (flexible spending) & 25 & 4 & - \\
\hline Employee assistance program & 22 & 6 & - \\
\hline Cafeteria benefit plan & 19 & 5 & 10 \\
\hline Tuition assistance & 19 & 12 & - \\
\hline 403(b) retirement & 17 & - & - \\
\hline Credit union membership & 13 & 6 & - \\
\hline Other (see list above) & 13 & - & - \\
\hline Transportation allowance & 12 & 39 & 37 \\
\hline Daycare for children & 4 & 1 & - \\
\hline 407 (k) & 0 & - & - \\
\hline
\end{tabular}

* In 1998 and 1993, the survey questionnaires did not specify type of retirement benefit but simI described the benefit as "retirement".

\section{Entity That Pays for Staff Benefits}

28. The above benefits are paid for by... (check one).

This was a new question in the 2003 TMA Survey. Out of the 97 potential respondents, 57 percent indicated that the TMA pays for benefits, 17 percent indicated that a parent organi pays for benefits, 21 percent indicated non-applicable and the remaining 5 percent other sources, including: “TMA and grant”, "city/county”, “TMO/special services c "government agency", and a combination of the TMA and parent organization jointly pror benefits. 


\section{Transportation Management Association (TMA) Survey}

\section{Use of Personnel Policy Document}

29a. Is your TMA staff guided by an adopted personnel policy document?

In 1993, a little over $25 \%$ of respondents had formally adopted personnel policies. In 2003, out of the 97 potential respondents, 33 percent do not have an adopted personnel policy document and 51 percent do. The other 16 percent indicated non-applicable or did not respond.

\section{Entity That Drafts/Administers Personnel Policy Document}

29b. If yes, the personnel policy document was drafted and is administered by... Please check only one.

This was a new question in the 2003 TMA Survey. Of those TMAs that have adopted personnel policy document, 37 percent are drafted and administered by TMA staff, another 39 percent are drafted and administered by the TMA parent and the remaining 24 percent have som other author, usually a combined effort of the TMA staff and the board of directors.

\section{Conduct of Staff Evaluations}

30a. Are TMA employee evaluations conducted?

In 1993, 33\% of TMAs conducted annual employee evaluations. In 2003, 63 percent o respondents indicated that employee evaluations were conducted.

\section{Entity That Conducts Evaluations}

30b. If yes, the employee evaluations are conducted by... Please check only one:

This was a new question in the 2003 TMA Survey. Fifty-eight percent of TMAs with employee evaluations indicated that the TMA staff and board conduct the evaluations while 17 pe indicated that the parent organization conducts the evaluations. The other 25 percent included a variety of answers, such as the executive director evaluates the staff and the board evaluates the executive director. Another common answer was the executive committee. 


\section{Transportation Management Association (TMA) Survey}

\section{Financial Characteristics}

\section{Size of Budget}

32. What were your TMA's expenditures for the most recently completed year?

This question was aimed at determining the general magnitude of the annual budget for TMAs. Out of the total 97 possible responses, three TMAs left the question blank. One of these three TMAs was newly forming. Nine more TMAs wrote n/a. It is conjectured that most of these are TMAs that are within a parent organization that controls the budget. In 2003, eight percent of TMA respondents had budgets of less than $\$ 50,000$ and five percent had budgets of \$1 million c more, with 82 percent of all budgets less than $\$ 500,000$. The median range of annual expenditures was between $\$ 150,000$ and $\$ 200,000$. This compares to a median range of $\$ 100$ 149,000 in 1998 . In 1993 , the mean budget was $\$ 149,000$ with a range of $\$ 50,000$ to $\$ 300,000$. While the increase in median budget is probably explained by inflation, the greater rang budget size across all TMAs can be accounted for by older, more established TMAs ha' further developed programs while the newer TMAs have smaller budgets. Larger budgets are also associated with the provision of transit services.

\section{Expenditures Breakdown}

33. Please estimate your expenditures breakdown for the most recently completed year. Where applicable, include labor, equipment, supplies and products for each item.

In 1993, TMAs spent on average 26 percent of total annual budgets on member services. In 2003, TMAs spent on average 24 percent of total annual budgets on member services. Howeve a closer look shows a wide range in the manner in which TMAs allocate their resources with regard to member services as shown below. In general, TMAs that provide shuttles or transit operations as a member service spend a larger proportion of their budget on member services.

This was a difficult question for many to answer because the line items differ from one TMA budget to another. Out of the 97 possible responses, 12 TMAs wrote n/a while another 16 TMA gave no response. Of the remaining 69 responses, seven TMAs broke salaries out as a separate item and included it in the "other" category. For those who did, salaries were listed as between 38 and 80 percent of total budget. For the remaining 62 survey responses, the expenditures wer broken down in Figure 23. For shuttles/transit operations, there were 33 TMAs that included a figure. The figures for this row were computed based only on those 33 responses. In one case, i TMA responded that their communications were covered by an in-kind contribution. The large range between highest and lowest responses illustrates that TMA budgets vary greatly. There is no “average” TMA budget. 


\section{Transportation Management Association (TMA) Survey}

Figure 23: Percentage of Total_Budget in 2003

\begin{tabular}{|l|ll|l}
\hline Item & Highest response & Lowest response & Mean \\
\hline $\begin{array}{l}\text { Office operations (including office } \\
\text { space, insurance) }\end{array}$ & 97 & 0 & 29 \\
\hline Marketing and promotion & 95 & 0 & 17 \\
\hline Shuttles/transit operations & 95 & 3 & 48 \\
\hline Other direct member services & 92 & 0 & 8 \\
\hline $\begin{array}{l}\text { Professional services (legal, } \\
\text { accounting) }\end{array}$ & 50 & 0 & 5 \\
\hline Travel & 35 & 0 & 2 \\
\hline $\begin{array}{l}\text { Communications (phone, web } \\
\text { postage) }\end{array}$ & 40 & 0 & 4 \\
\hline Other & 60 & 0 & 4 \\
\hline
\end{tabular}

Most respondents did not provide a percentage for "other." Those who specified other items included special events, indirect costs, surveys, and information technology. Some TMA separated out the cost of labor and included it in the "other" category of expenses instead of incorporating it into the cost of the various line items.

\section{Income Sources and Percent of Total Budget}

34. What percentage of your TMA's income is derived from the following sources for the $r$ recently completed year?

In 1993, 20 percent of respondents obtained 100 percent of their funding from dues. Dues made up 47 percent of average total revenue. In 2003, 5 percent of respondents obtained 100 percent funding from dues and dues made up 40 percent of average total revenue.

In the 2003 TMA Survey, there was a longer list of answer options than was provided previous surveys. Of the 97 possible responses, 12 TMAs replied with n/a, and four more TMA did not supply an answer. Of the 81 remaining TMAs, nine TMAs received income frr single source. Five of these TMAs received 100 percent of their funding from member dues, on TMA received 100 percent funding from developer funding agreements, one TMA received 100 percent funding from a business improvement district, one TMA received 100 percent funding from a state grant and the last TMA received 100 percent funding from a local grant. The remaining 72 TMAs received funding from two or more sources. The percentage of all TMAs who responded to the question that they receive funds from either single or multiple sources is a follows: 


\section{Transportation Management Association (TMA) Survey}

56\% Member dues (or 45 of the TMAs that responded to the question assess member dues)

48\% Federal grants

28\% Local grants

$27 \%$ State grants

$27 \%$ Other (see discussion below)

25\% In-kind donations

$19 \%$ Service contracts

$16 \%$ Fees for services

9\% Developer funding agreements

7\% Business improvement districts

$1 \%$ Community financing district

“Other” funding sources listed included transit fares, private grants, taxes, municipal sponsors, parent organization, foundation grants, vanpool revenues, promotional events, parking fees and company investments.

Across all TMAs who provided a value for the following income sources, the average percentag of a TMA's income derived from the following sources is listed in Figure 24.

Figure 24: Percentage of TMA Income_Derived From Various_Sources

\begin{tabular}{|l|lll}
\hline Source & $\begin{array}{l}\text { \% of TMAs } \\
\text { providing a value } \\
\text { for this source }\end{array}$ & $\begin{array}{l}\text { Range of \% total } \\
\text { income for TMAs with } \\
\text { this income source }\end{array}$ & $\begin{array}{l}\text { Average \% of } \\
\text { TMA's total } \\
\text { income }\end{array}$ \\
\hline Dues & 47 & $3-100$ & 40 \\
\hline Fees for services & 13 & $1-90$ & 28 \\
\hline Service contracts & 15 & $1-95$ & 38 \\
\hline Developer funding agreements & 7 & $4-100$ & 37 \\
\hline Business improvement district & 6 & $8-100$ & 48 \\
\hline Community financing district & 1 & -- & 95 \\
\hline Federal grants & 40 & $1-91$ & 52 \\
\hline State grants & 23 & $3-100$ & 33 \\
\hline Local grants & 24 & $1-100$ & 20 \\
\hline In-kind donations & 21 & $1-30$ & 39 \\
\hline Other & 22 & $4.4-100$ & 11 \\
\hline
\end{tabular}

When comparing this data with the responses for question \#35 below, some TMAs who supplier dues rate structures were ones that provided no value for dues as an income source. $T$ TMAs had other forms of income sources, but used question \#35 as a means of explaining them 


\section{Transportation Management Association (TMA) Survey}

even though they are not membership dues per se. For example, four of the TMAs have rate structures as part of a business or community improvement district or developer agreem $\epsilon$ Their memberships pay taxes, not dues. Another TMA assesses "partnership fees” based on the number of employers in each jurisdiction that are affected by a state commute trip reduction law Another TMA uses expense sharing by local government as a form of member dues, but this wa categorized as a local grant in Question 34 rather than member dues.

\section{Dues Structure}

35. On what basis are annual membership dues assessments structured?

The survey requested more specific information regarding member dues and provided a longer list of answer options than previous surveys. Figure 25 illustrates the use of various types of dues assessments, based upon 42 TMAs that responded to the question. Some TMAs used a combination of more than one type of dues assessment.

Figure 25: Membership Dues Assessment

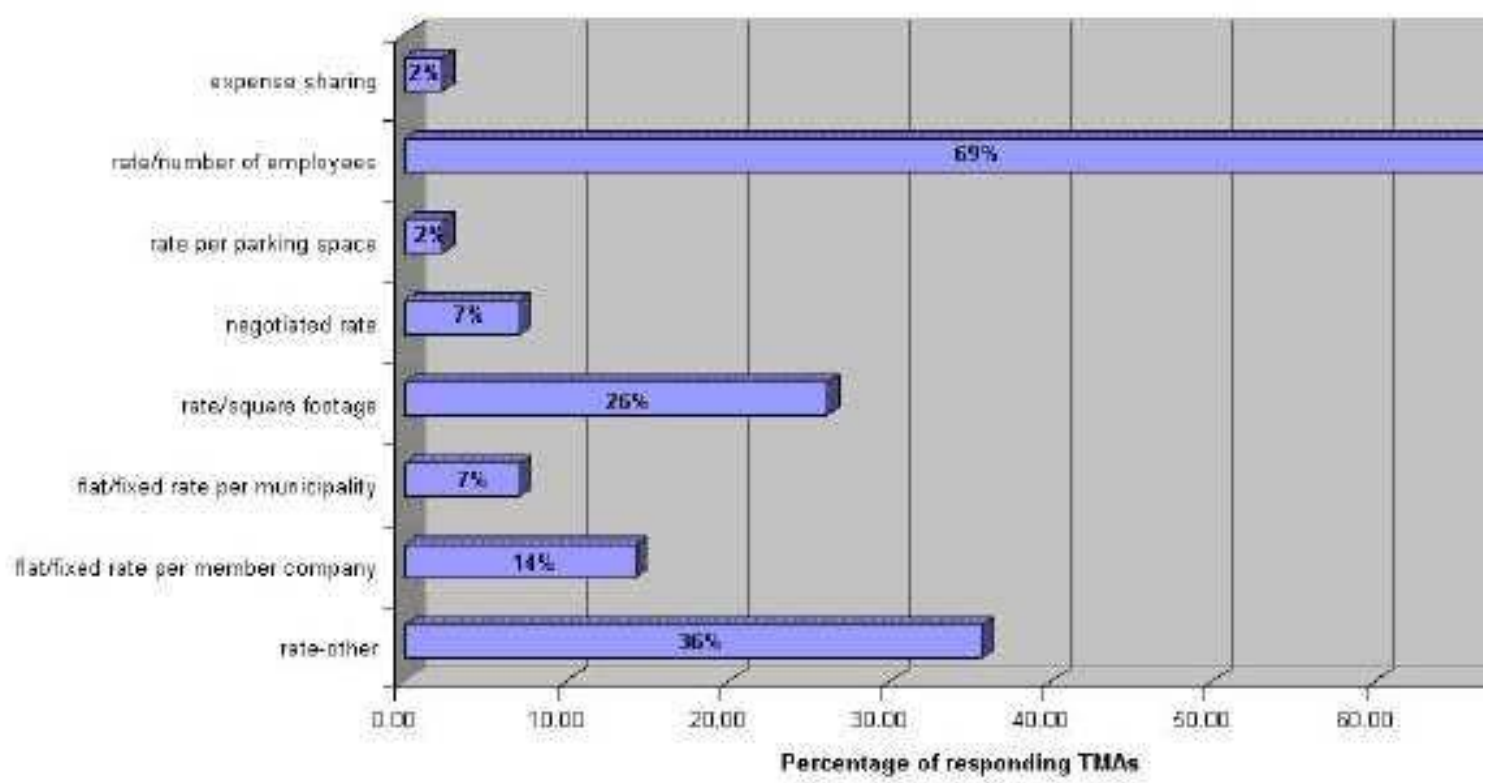

Sixty-nine percent of the responding TMAs used a fee structure based on number of employees. Most of these TMAs used a straight cost per employee, charging fees ranging from $\$ 1$ to $\$ 12$, with a mean value of $\$ 4.84$. Four TMAs placed minimum/maximum limits on the char another exempted government agencies, and one used a 1/3 reduction for non-profit companies. 


\section{Transportation Management Association (TMA) Survey}

The remainder of this group of TMAs set rates based on a selected number of employees. average all but one of these charges based on a per employee rate (favoring the highest fees possible), it was determined the average rate per employee was $\$ 9.22$.

Figure 26 illustrates a sample distribution of annual rates for a selected number of employ

Figure 26: Sample Member Fees Assessed By Range of Number of Employees

\begin{tabular}{|ll|}
\hline Number of Employees & Fee Assessed \\
100 & $\$ 500$ \\
$101-250$ & $\$ 1,500$ \\
$251-500$ & $\$ 6,500$ \\
$501-1000$ & $\$ 9,500$ \\
$>1000$ & $\$ 13,500$ \\
\hline
\end{tabular}

For the respondents that use a fixed rate per member company, the fees charged range from $\$ 5.00$ to $\$ 5000$ per member company with an average fee of $\$ 212$. Respondents who use per municipality use either a fee of $\$ 500$ per municipality or charge $\$ 0.10$ per resident or $\leqslant$

Rates charged per square foot ranged from $\$ 0.005$ to $\$ 0.3$ per square foot. The median rat $\$ 0.07$ and the mean was $\$ 0.027$. Two TMAs charged fees according to business another used an exemption for non-profit companies. Figure 27 shows a comparison of th of dues assessment types between the years 1993 and 2003. It indicates that assessments by square footage are now more prevalent than 10 years ago while assessments as a fixed ratt company have become less prevalent. 


\section{Transportation Management Association (TMA) Survey}

Figure 27: Comparison of Use of Dues Assessment Types

\begin{tabular}{|c|c|c|}
\hline Assessment Types & 1993 & 2003 \\
\hline Total number of employees & $\begin{array}{l}\text { 61\%, from } \$ 0.50 \text { to } \$ 18 \text { per } \\
\text { employee }\end{array}$ & $\begin{array}{l}\text { 69\%, from } \$ 1 \text { to } \$ 12 \text { per } \\
\text { employee }\end{array}$ \\
\hline Other & $33 \%$ & $36 \%$ \\
\hline Fixed rate per company & $\begin{array}{l}\mathbf{2 4 \%} \text {, mean annual fixed base } \\
\text { rate of } \$ 605\end{array}$ & $\mathbf{1 4 \%}$, from $\$ 5$ to $\$ 5,000$ \\
\hline Square footage & $\mathbf{1 4} \%$, mean charge of $\$ 0.07$ & $\begin{array}{l}\mathbf{2 6 \%}, \text { from } \$ 0.005 \text { to } \$ 0.3 \\
\text { mean of } \$ 0.027\end{array}$ \\
\hline Fixed rate per municipality & -- & 7\%, \$500 per municipalit \\
\hline Negotiated rate & -- & $7 \%$ \\
\hline Parking space & -- & $2 \%$ \\
\hline Expense sharing & -- & $2 \%$ \\
\hline
\end{tabular}

In 2003, as in 1993, fully a third of all TMAs assessing dues used some other criteria. Here is a listing of those cited by these TMAs in 2003:

Hotel room fees

Associate fees for non service area members

Event center charges per visitor

Fee assessment based on type of business, i.e. Engineering, Planners

Rate based on the size of employer using various factors and determined by th director and committee

Associate fees for service providers, consultants, and government agencies

A defined tax district or dedicated tax revenues

Number of employees in each jurisdiction per state law

Combination of parking fees and company investments

Defined point system based on dwelling units or number of employees

Fees based on township/city population

Fees per resident multi-family or single family dwelling units

Company donations

Fees based on classification of a city or town 


\section{Transportation Management Association (TMA) Survey}

\section{Member Discounts}

36. Do you offer discounts to any of the following members or member groups?

In 1998, three percent of TMAs recruited members through a discounted rate. In percent of responding TMAs indicated that they offer member discounts. The most cited was non-profit organizations. Other groups cited were new members, long time m individuals and government.

\section{Annual Audit}

37. Are your TMA's financial records audited annually?

In 1998, 75 percent of TMAs conducted an annual audit of financial records. In 2003, 59 of all TMAs conducted an annual audit.

\section{Annual Financial Statement}

38. Does your TMA provide an annual financial statement to members?

In 1993, 66 percent of TMAs provided an annual financial report to members. This decrei 57 percent in 1998 and in 2003, 54 percent of TMAs did so. Looking closer at the data, it appears that the apparent drop in the number of TMAs submitting annual financial reports is accounted for by the number of new informally organized TMAs that operate under the pr of an umbrella program as well as other TMAs that operate as a subsidiary of a ] organization.

\section{Method of Accounting}

39. What method of accounting is used to generate the TMA's financial records?

In 2003, 25 percent of responding TMAs used the cash method of accounting, another 25 of TMAs used the accrual method, 12 percent of TMAs use a combination of cash and acc 16 percent indicated that the TMA accounting method is unknown because it is conducted parent organization, and 22 percent of TMAs did not respond to the question. 


\section{Transportation Management Association (TMA) Survey}

\section{Own/Lease Office Space}

40. Does your TMA own or lease office space for its headquarters?

In 1993, 50 percent of all TMAs leased space in a building and 39 percent received donated space in a member's building. In 1998, 57 percent leased office space, 37 percen donated space and five percent owned office space. In 2003, out of the 97 potential respol 22 percent of TMAs leased space in a building at full market rate, another 22 per space in a building at a discounted rate, 24 percent received donated space in a $\mathrm{m}$ building, and 3 percent owned their office space. Figure 28 illustrates these comp Another 22 percent of respondents indicated that their TMAs neither lease, own, nor receive donated office space. For many informal TMAs whose activities are housed under the pu of parent organizations, the TMA does not account for the office space. One TMA shares with the marketing and property owners' association. Another TMA has three offi different arrangements for each. The final seven percent did not respond to the question. comparison indicates that less TMAs today lease office space.

Figure 28: Office Space Arrangements

\begin{tabular}{|c|c|c|c|c|c|}
\hline & \multicolumn{2}{|c|}{\begin{tabular}{|l} 
Lease office space \\
\end{tabular}} & $\begin{array}{l}\text { Received } \\
\text { donated space }\end{array}$ & $\begin{array}{l}\text { Owned office } \\
\text { space }\end{array}$ & $\begin{array}{l}\text { Neither } \\
\text { nor leas }\end{array}$ \\
\hline 1993 & \multicolumn{2}{|l|}{\begin{tabular}{|l|}
$50 \%$ \\
\end{tabular}} & $39 \%$ & -- & -- \\
\hline 1998 & \multicolumn{2}{|l|}{$57 \%$} & $37 \%$ & $5 \%$ & -- \\
\hline \multirow[t]{2}{*}{2003} & $\begin{array}{l}\text { Discounted } \\
\text { rate }\end{array}$ & $\begin{array}{l}\text { Full market } \\
\text { rate }\end{array}$ & \multirow[t]{2}{*}{$24 \%$} & \multirow[t]{2}{*}{$3 \%$} & \multirow[t]{2}{*}{$22 \%$} \\
\hline & \begin{tabular}{|l|}
$22 \%$ \\
\end{tabular} & $22 \%$ & & & \\
\hline
\end{tabular}




\section{Transportation Management Association (TMA) Survey}

\section{Organizational Characteristics}

\section{Organizations Instrumental in Forming TMA}

42. What types of organizations were instrumental in forming your TMA?

This was a new question in the 2003 TMA Survey. Of the 96 TMAs that responded to this question, just 11 TMAs indicated that a single type of organization was instrumental. These included seven TMAs in which a group of employers organized the TMA. Two TMAs in that their organization formed as a result of developers only. Two additional TMAs indici that the parent organization and a transportation planning agency were instrumental. The 85 TMAs indicated that various combinations of different organizational types collaborat $\epsilon$ form the TMA. This confirms the idea that TMAs function as partnerships. The percenta: TMAs that indicated the following groups were instrumental in TMA formation is as follo
$72 \% \quad$ Employers
52\% Transportation planning agencies
43\% "Other” organizations as listed below
41\% Metropolitan planning organizations
31\% Developers
$16 \%$ Community/residential organizations
10\% Environmental government agencies

“Other” organizing partners included cities and town planning boards, chambers of comm transit agencies, universities and educational institutions, hospitals, airport, trans consultants, employment service, air quality group, property owners, a state legislature, th Congress in one instance, the governor, and an economic development corporation.

\section{Issues Prompting TMA Formation}

43. What issues or concerns prompted the formation of your TMA?

This was a new question in the 2003 TMA Survey. Instead of checking answer options, the respondents had to write an answer. Of the 62 TMAs providing their mission stat TMAs indicated the topics, shown in Figure 29, as providing reasons for starting the TMA 


\section{Transportation Management Association (TMA) Survey}

Figure 29: Issues Prompting TMA Formation

\begin{tabular}{|c|c|}
\hline Reason for TMA Formation & Percentage of Respondents \\
\hline Congestion & 56 \\
\hline Growth & 17 \\
\hline New development & 13 \\
\hline Transit & 13 \\
\hline Air Quality & 11 \\
\hline Parking & 9 \\
\hline Regulation & 9 \\
\hline New road/highway & 4 \\
\hline Trip reduction & 4 \\
\hline Land use & 2 \\
\hline
\end{tabular}

It is possible that "growth" and "new development" are the same, but enough TMAs used different wording that these were kept separate in the tally above. Several additional entri included concerns regarding commutes, economic slowdown, special events and employe] initiated issues.

\section{Mission Statement}

44. "What is your TMA's mission statement?"

This was a new question in the TMA Survey and required respondents to write an answer. central focus of TMAs has not changed in the last 10 years. The 1993 survey found TMAs representing a variety of missions, with some focusing on policy leadership and advocacy other TMAs focused on providing services. In 2003, we again find a variety of missions, percent of TMAs citing improved travel, mobility, accessibility or reduction in traffic con! at the heart of their missions.

Sixty-two respondents in the TMA survey included their mission statements. Figur summarizes the most common mission statement themes. Of these, 68 percent of TMAs $s$ primary mission was to improve mobility/accessibility or a reduction in congestion. Alter forms of transportation or reduced single occupancy vehicles were the primary mission fo] percent of TMAs. An additional 34 percent stated improved air quality as a primary missi 19 percent indicated economic development as a primary mission. Several other factors $\mathrm{u}$ also noted and are listed in Figure 30. 


\section{Transportation Management Association (TMA) Survey}

Figure 30: TMA Mission Statement Themes

\begin{tabular}{|l|c}
\hline Mission Statements & \% of TMA \\
\hline Improve travel, mobility, accessibility or reduce congestion & 68 \\
\hline $\begin{array}{l}\text { Use alternative forms of transportation/TDM or reduce use of single } \\
\text { occupant vehicles }\end{array}$ & 42 \\
\hline Improve air quality & 34 \\
\hline Promote economic development & 19 \\
\hline Provide and promote commute options & 13 \\
\hline Increase quality of life & 10 \\
\hline Educate commuters, employers and policy makers & 7 \\
\hline Act as a liaison for transportation alternative & 6 \\
\hline Increase transit use & 5 \\
\hline Alleviate parking issues & 5 \\
\hline Improve existing infrastructure & 3 \\
\hline Minimize impact of land use & 3 \\
\hline
\end{tabular}

\section{Authority That Decides Final Actions}

45. What type of authority decides final actions for the TMA?

Of the 97 total possible responses, 95 TMAs provided an answer. As Figure 31 j approximately 63 percent indicated that an authority composed of membership only decid actions. This is a minor increase from 57 percent in 1998. Another 18 percent indicated $t$ some other authority decides final actions. Answers given included a regional pub authority; a combination of membership and a community improvement district; a combin of a chamber, local improvement district and appointed officials; staff with a coun governments; a property owner and a city/county government. Another 15 percent indicat final actions of the TMA are decided by a combination of the membership and local gover This is a decrease from 1998, in which 23 percent of TMAs indicated final actions were di by a combination of membership and government. An additional 4 percent indicat chambers of commerce, transportation/local improvement districts, or appointed officials/: committees decide final actions. 


\section{Transportation Management Association (TMA) Survey}

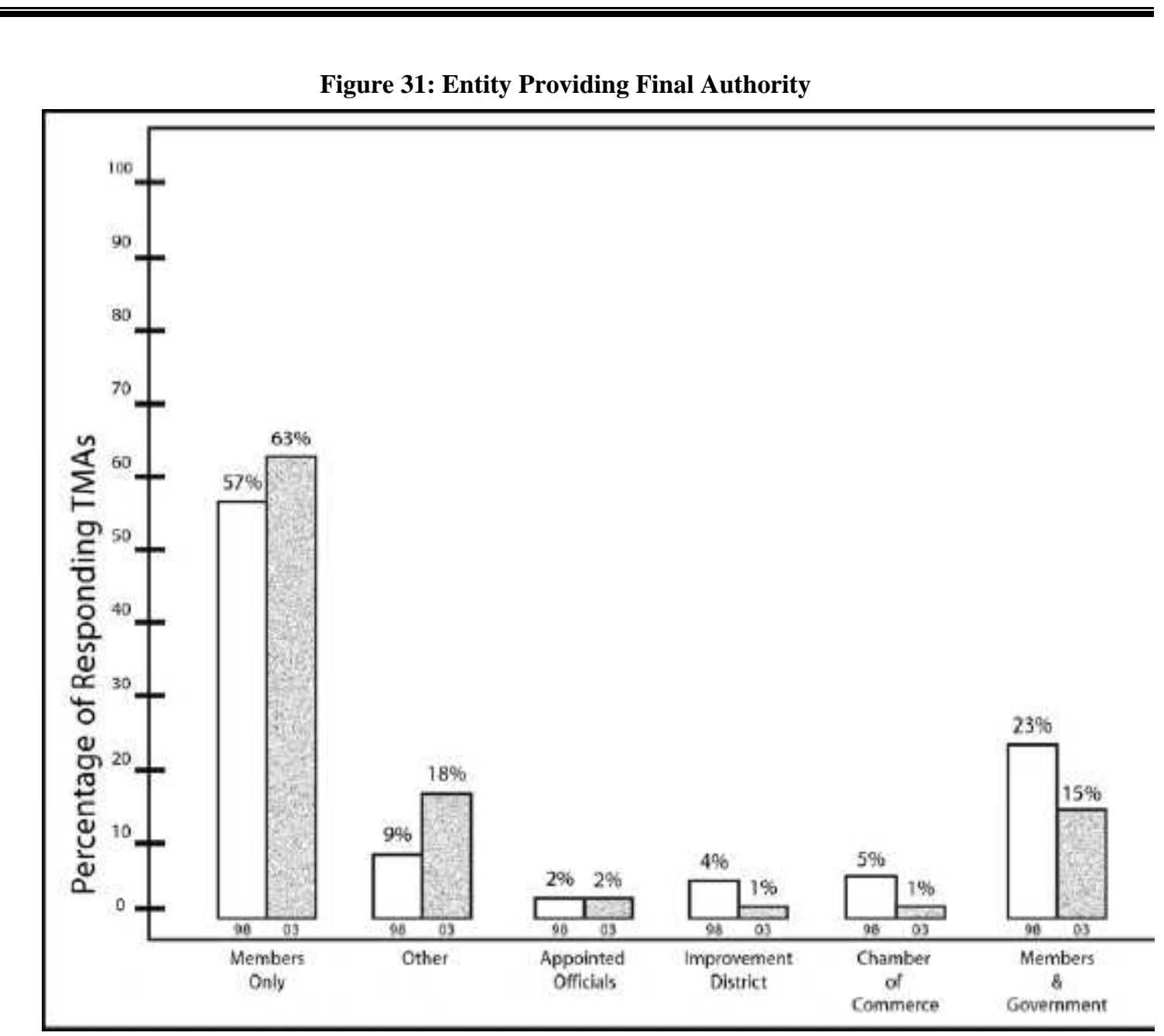

\section{Annual Meeting}

46. Does your TMA conduct an annual full member meeting?

In 1993, 80 percent of TMAs held annual meetings, while in 2003, 65 percent of TMAs hr annual meetings. Of the 97 possible responses, 13 respondents did not provide an answer. the remaining 84, 65 percent (55) said yes and 33 percent (28) said no. One respondent in that the question did not apply. One ambiguity about the question is that those saying no $t$ question could actually be conducting “annual” meetings and conducting the kind of repor that ordinarily takes place at annual meetings, but on a different schedule, such as semi-an or every 18 months, 2 years, as needed, etc. 


\section{Transportation Management Association (TMA) Survey}

\section{TMA Formation}

\section{When was your TMA formed (month/year)?}

Of the 97 possible responses, 4 did not answer. The earliest year of formation was given 1973 and the latest year 2002. There were six TMAs that just formed in the past year (ont existed since 1995 and formally incorporated in 2003 and is reorganizing). One T scheduled to disband in June 2003, after a corridor construction project was compl indicating that not all TMAs are formed with the intention of being permanent organization TMAs were forming at a low (1-2) but steady rate between 1979 and 1988. Then in 1989, was a sharp increase in the number of TMAs forming each year, which lasted thr Since 1998 and the time of the last TMA survey, new TMAs have continued to form but a lower rate of about four per year. Figure 32 shows the number of new TMAs formed duri each 5-year period.

Figure 32: TMA Growth Rate

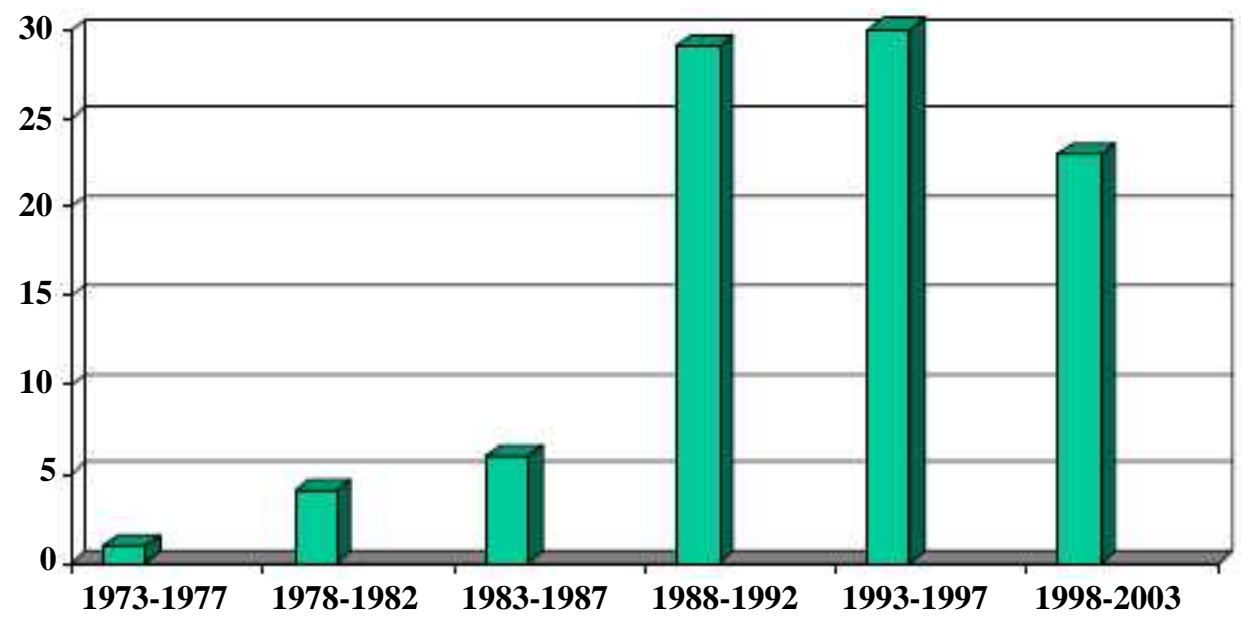




\section{Transportation Management Association (TMA) Survey}

\section{Incorporation and Tax Status}

48a). Is your TMA incorporated?

In 1993, 78 percent of TMAs were incorporated while in 2003, 56 percent of TMAs w incorporated. The results indicate an increase in the proportion of TMAs who operate under an informal organizational structure. Section 501(c)(4) organizations appear to be the slightly mor prevalent tax status in 2003, as contrasted by the prevalence of 501(c)(3) organizations in 1993. Figure 33 describes the break down of TMAs among 501(c) organizations. ${ }^{3}$

Figure 33: Comparison of TMA Incorporation Status

\begin{tabular}{|l|l|l|l}
\hline Incorporation Status & $\mathbf{1 9 9 3}$ & $\mathbf{1 9 9 8}$ & $\mathbf{2 0 0 3}$ \\
\hline $501(\mathrm{c})(3)$ & $35 \%$ & $37 \%$ & $21 \%$ \\
\hline $501(\mathrm{c})(4)$ & $30 \%$ & $17 \%$ & $27 \%$ \\
\hline $501(\mathrm{c})(5)$ & -- & -- & $1 \%$ \\
\hline $501(\mathrm{c})(6)$ & $13 \%$ & $17 \%$ & $7 \%$ \\
\hline Total TMAs Incorporated & $78 \%$ & $71 \%$ & $56 \%$ \\
\hline
\end{tabular}

If YES, what is the tax status of your TMA?

Figure 34 illustrates the distribution of incorporation designation, based upon differ membership definitions, as defined in the discussion for question 8. A question was raised abou whether more 501(c)(4) organizations got started later because it may have become hard incorporate as a 501(c)(3). The data do not bear this out. Comparing tax status of organizations based upon date of organization, both the 501(c)(3) and the 501(c)(4) organizations incorporatec over approximately the same time period and at the same rate.

\footnotetext{
${ }^{3}$ For additional discussion about the differences among 501(c) organizations, refer to the TMA Handbook: A Guide to Successful Transportation Management Associations, 2001 Edition, Section 3. The TMA Handbook is distributed by the Association for Commuter Transportation.
} 


\section{Transportation Management Association (TMA) Survey}

Figure_34: Status of TMA_Incorporation

\begin{tabular}{|l|l|llll|l|l|l|l}
\hline & \#TMAs & Uninc'd & Inc'd & $\mathbf{5 0 1 ( c ) ( 3 )}$ & $\mathbf{5 0 1 ( c ) ( 4 )}$ & $\mathbf{5 0}$ & $\mathbf{( c ) ( 6 )}$ & Other & Unknov \\
\hline $\begin{array}{l}\text { Member } \\
\text { companies }\end{array}$ & 32 & 1 & 31 & 12 & 13 & 6 & 0 & 0 \\
\hline $\begin{array}{l}\text { Members } \\
\text { as board } \\
\text { participants }\end{array}$ & 20 & 3 & 17 & 7 & 9 & 0 & 0 & 1 \\
\hline $\begin{array}{l}\text { Members } \\
\text { as property } \\
\text { owners }\end{array}$ & 8 & 2 & 6 & 1 & 3 & 1 & 0 & 1 \\
\hline $\begin{array}{l}\text { Members } \\
\text { as service } \\
\text { recipients }\end{array}$ & 1 & 0 & 1 & 0 & 1 & 0 & & 0 & 0 \\
\hline Total & 61 & 6 & 55 & 20 & 26 & 7 & 0 & 2 \\
\hline
\end{tabular}

\section{Parent Organization}

48b). If NO to Question 48a), is your TMA a subsidiary of or part of a parent organization (e.g. a program within a chamber of commerce or a business improvement district)?

This was a new question in the 2003 TMA Survey. Approximately 36 percent of TMAs are organized within a parent organization.

48c). If you answered YES to 48b), what is the tax status of your parent organization under the Internal Revenue Code?

Figure 35 illustrates the tax designation of parent organizations sponsoring TMAs.

Figure 35: Tax Status of Parent Organizations for TMAs Having Joint Memberships

\begin{tabular}{|l|l|l|l|l|l|}
\hline \# TMAs & $\mathbf{5 0 1 ( C ) ( 3 )}$ & $\mathbf{5 0 1 ( C ) ( 4 )}$ & $\mathbf{5 0 1 ( C ) ( 5 )}$ & $\mathbf{5 0 1 ( C ) ( 6 )}$ & Unknown \\
\hline 34 & 7 & 1 & 1 & 3 & 22 \\
\hline
\end{tabular}




\section{Transportation Management Association (TMA) Survey}

49. If you answered YES to 48b), what type of parent organization sponsors your TMA? Check only one.

This was a new question to the 2003 TMA survey. Twelve of the TMAs were from Arizona anc were organized under the purview of the regional public transportation agency. The other 22 TMAs described their parent organizations as follows.

$\begin{array}{ll}7 & \text { unknown } \\ 2 & \text { business association } \\ 2 & \text { nonprofit service organization } \\ 2 & \text { downtown association } \\ 1 & \text { economic development council } \\ 1 & \text { business advocacy group } \\ 1 & \text { downtown commuting alliance } \\ 1 & \text { chamber of commerce } \\ 1 & \text { business league } \\ 1 & \text { city/county } \\ 1 & \text { MPO } \\ 1 & \text { federal government } \\ 1 & \text { other }\end{array}$

\section{Governing Board Voting Members}

50. How many voting members are on your TMA's governing board?

In 1998 (no data for 1993), the number of board members ranged from one to 47 with an averag of 12 . In 2003, the number of the board members ranged from three to 77 members averaged 15 members. Figure 36 illustrates the distribution in the number of TMA board voting members in 2003. 


\section{Transportation Management Association (TMA) Survey}

Figure 36: Distribution in Numbers of TMA Board Voting Members

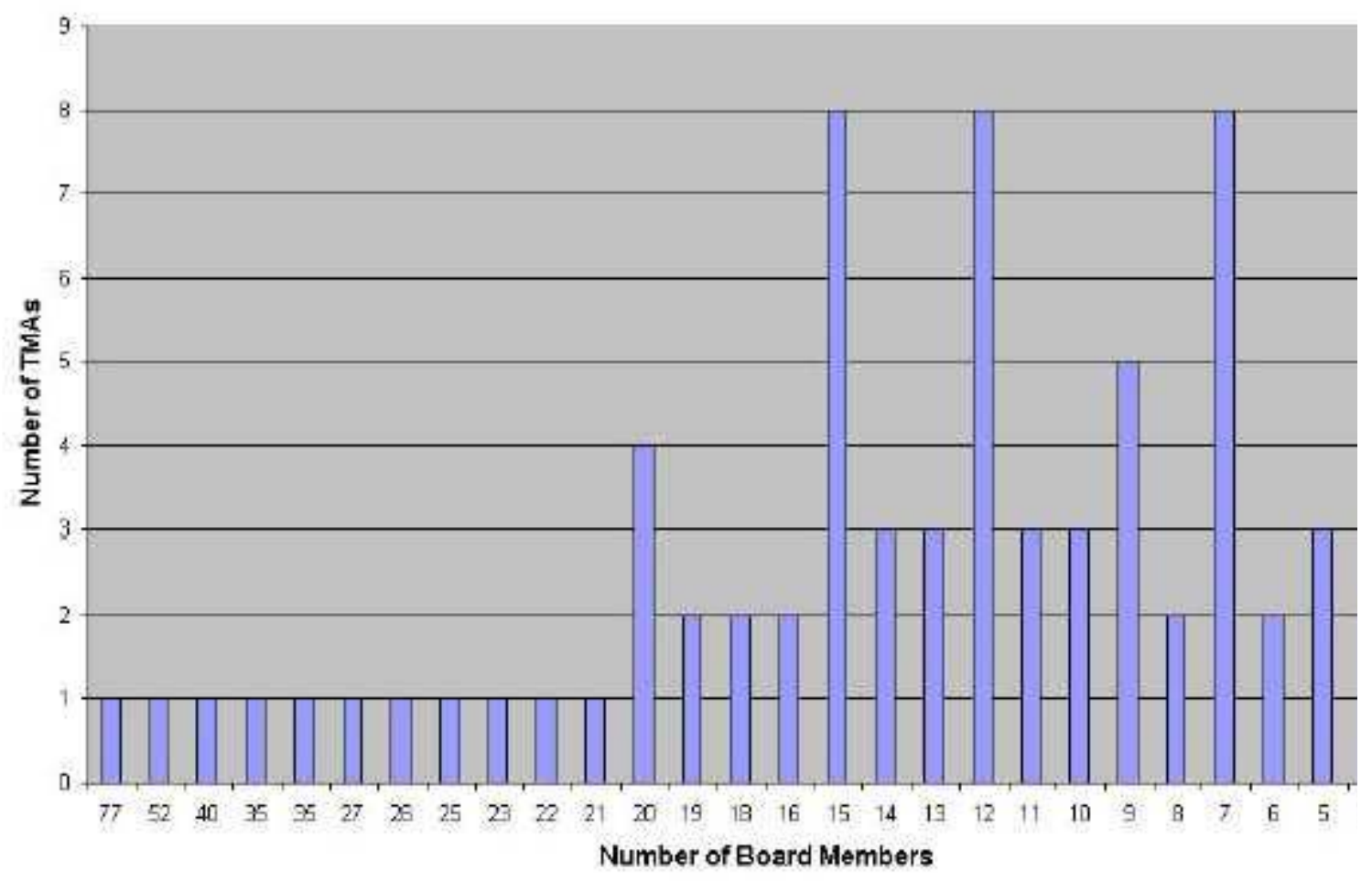

\section{Governing Board Non-Voting Members}

\section{How many non-voting members are on your TMA's governing board?}

As shown in Figure 37, the range of non-voting (ex-officio) members participating was frc to 34 members with an average of five non-voting members in 2003. In 1998, the averag $\epsilon$ had one non-voting member. 


\section{Transportation Management Association (TMA) Survey}

Figure 37: Distribution in Numbers of TMA Board Non-Voting Members

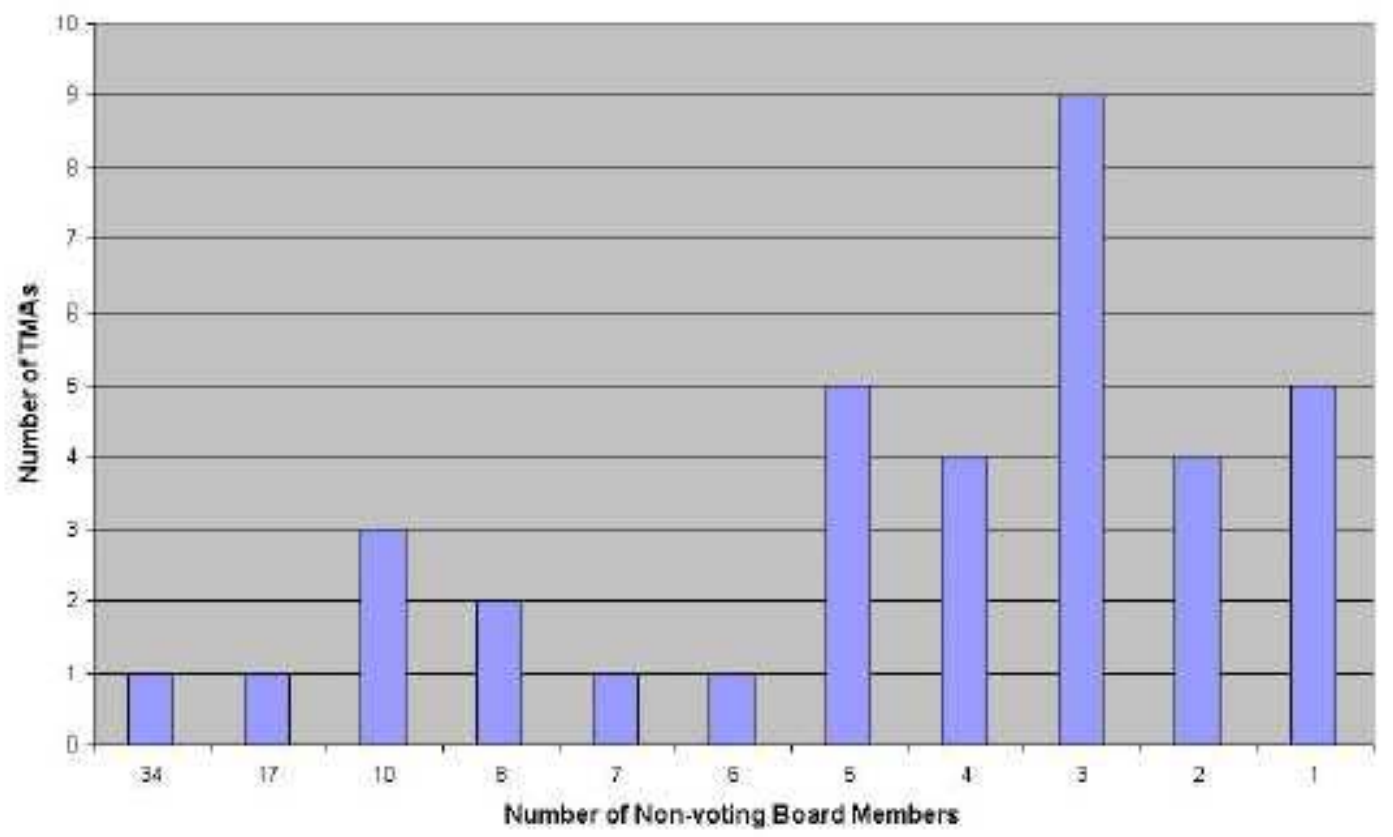

\section{Organizations Represented as Non-Voting Members}

52. Please list non-voting board members.

Figure 38 lists the types of non-voting members and the percentage of TMAs with each type of non-voting member.

Figure 38: Percentage of TMAs with Non-Voting Board Member Types

\begin{tabular}{|l|l}
\hline Non-voting member & \% of TMAs with Non-Voting Members \\
\hline Executive Director & 24 \\
\hline Transit Authority & 24 \\
\hline Metropolitan Planning Organization & 20 \\
\hline Department of Transportation & 16 \\
\hline City & 13 \\
\hline County & 5
\end{tabular}

Some examples of other types of non-voting members not included in Figure 38 were chamber officials, public officials, city planners, parent employees, turnpike authorities, neighborhc groups, legal council, college officials, police and the business community. Three TMAs did no 


\section{Transportation Management Association (TMA) Survey}

report their board composition and three additional TMAs used other types governing/advisory members such as volunteers, officers, and a transportation committee.

\section{Term of Office Length}

53. How long is a term of office for a board member? Check one.

In 2003, 33 TMAs used term limits in board governance and they ranged from one to four years as illustrated in Figure 39. In 1998, board members had two-year terms, on average.

Figure 39: Board Member Term Limits

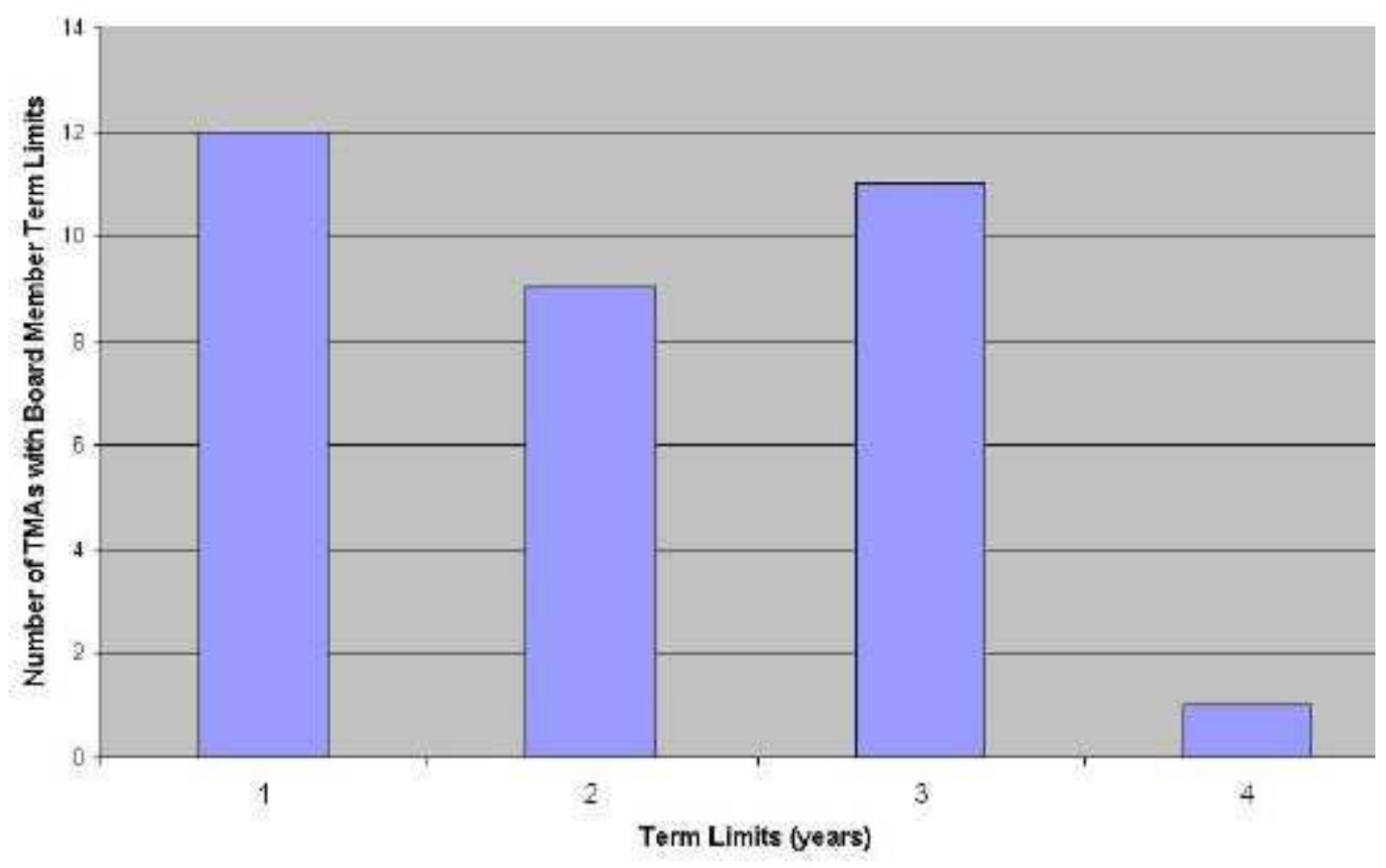

\section{Board Member Maximum Number of Terms}

54. What is the maximum number of terms that a board member may serve? Check one.

This was a new question in the 2003 TMA Survey. Only nine TMAs set maximum terms. Thes ranged from one to three terms. 


\section{Transportation Management Association (TMA) Survey}

\section{Board Officer Length of Office Term}

55. How long is a term of office for a board officer (i.e., Chair, President)?

This was a new question in the 2003 TMA Survey. Thirty-eight of the TMAs set term limits for the board officer, as described in Figure 40.

\section{Figure 40: Board Officer Term Limits}

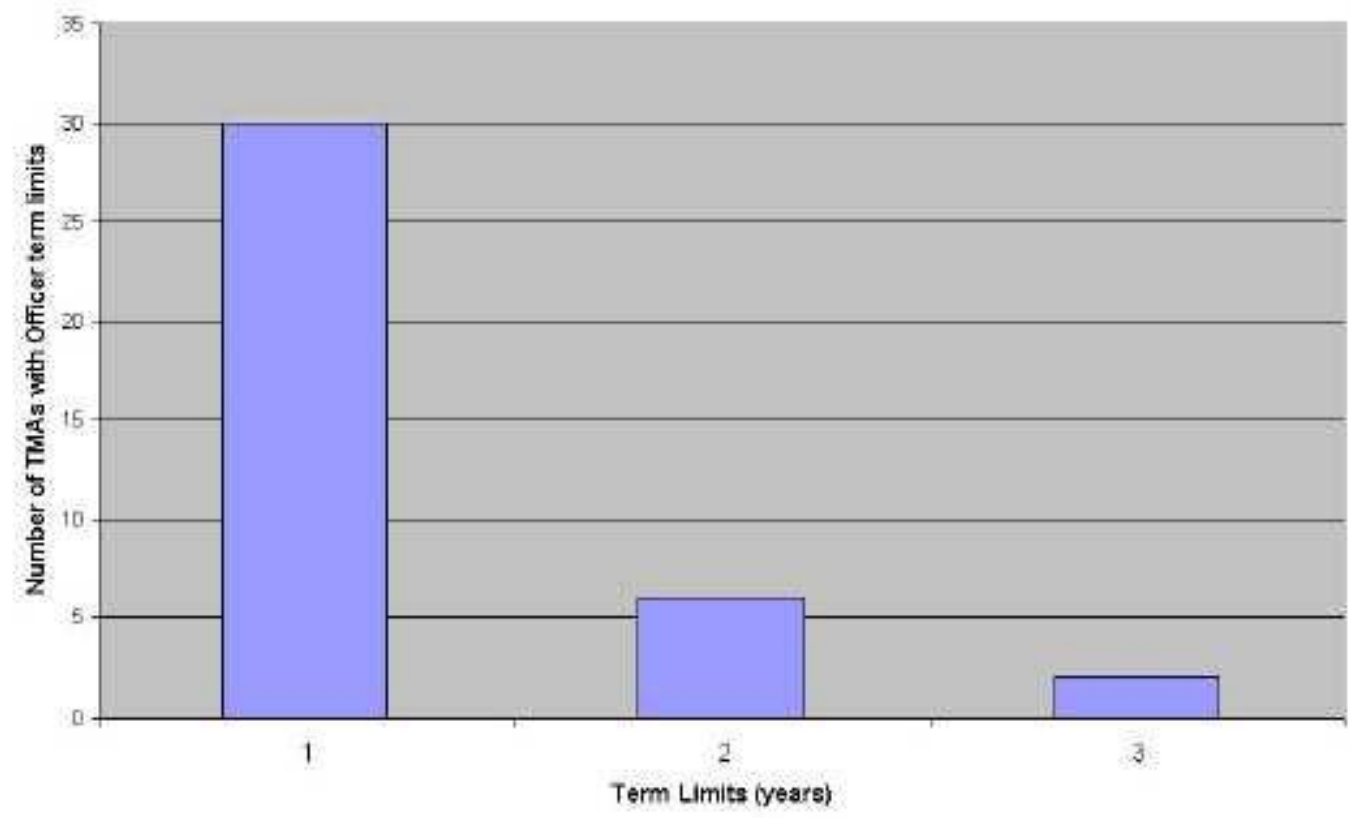

\section{Board Officer Maximum Number of Consecutive Terms}

56. What is the maximum number of consecutive terms that a board member may hold an officer position? Check one.

This was a new question in the 2003 TMA Survey. Only five TMAs had set a maximum numbe of terms. The limit was either one or two terms. This may be an indication of how difficult it is to find good leadership for the TMA. Once a competent and willing board officer is found, it may not be easy to let them go if finding a replacement is not possible. One argument is that a TMA should not let go of a great TMA leader but the downside is that individual personalities may put too much of a mark on the organization. It allows other potential leaders to grow complacent, feel less needed and lose a sense of responsibility and "ownership" of the organization. Holding on too long to a board officer disallows fresh ideas and perspectives that 


\section{Transportation Management Association (TMA) Survey}

naturally come with periodic turnover of leadership. If the long-time officer sudden there is a yawning vacuum of leadership that may be more difficult to fill.

\section{Board Meetings}

57. How often is the full board of directors required to meet? Check one.

In 1993, TMA boards met an average of 5.6 times per year. In 1998, the frequency with $\mathrm{v}$ most TMA boards were required to meet was either quarterly (32 percent) or mon percent) with an average of seven times per year. In 2003, TMA boards were required to ] on average 4.5 times per year. The 57 TMAs who responded to the question indicated tha boards met regularly as depicted in Figure 41 . There may be some ambiguity to this quest the sense that not all boards have a meeting frequency requirement and the resulting answ indicate how frequently boards actually meet.

Figure 41: Number of Required Board Meeting Times Per Year

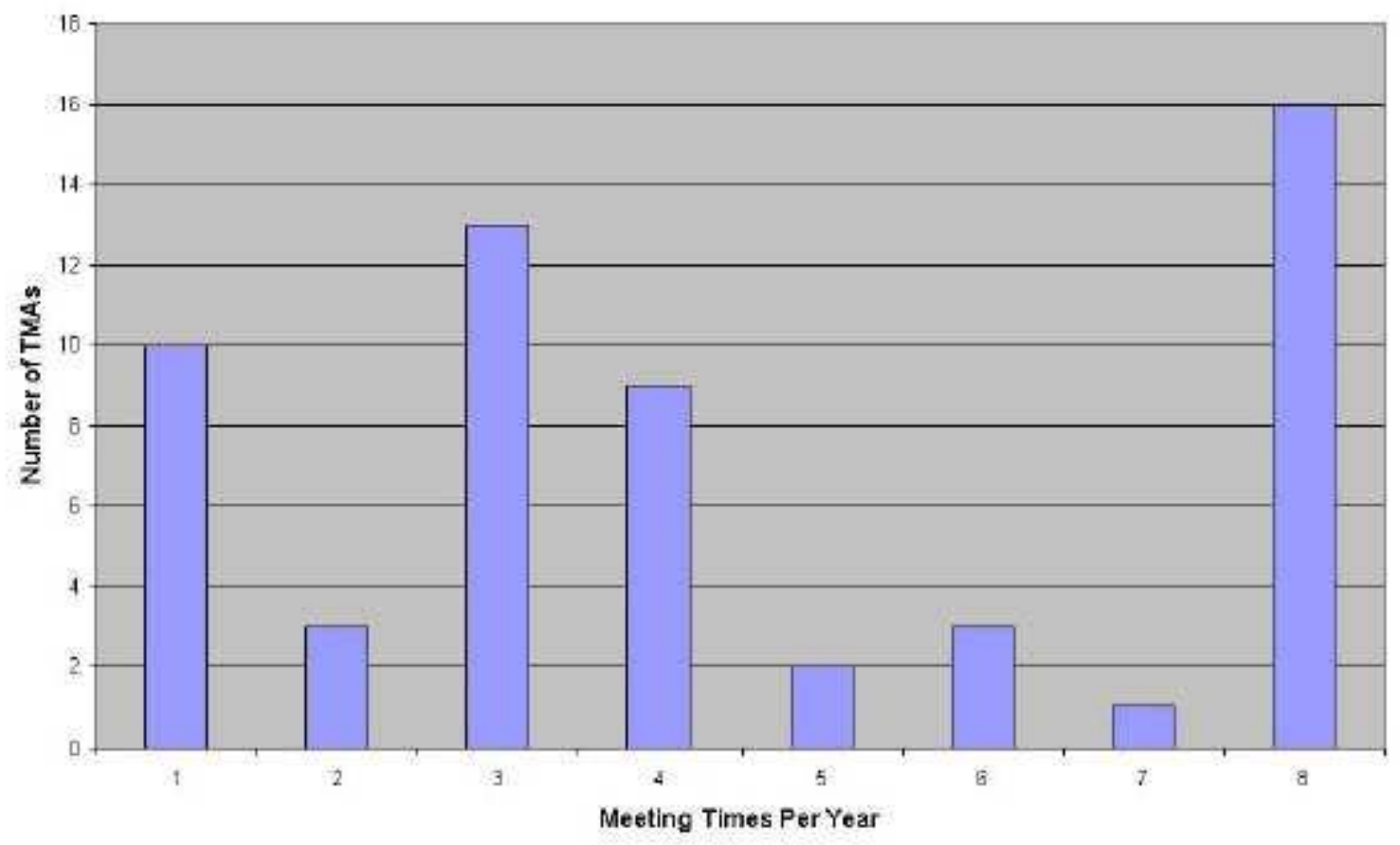




\section{Transportation Management Association (TMA) Survey}

\section{Board Recruitment Activities}

58. How do you fill board positions? Check all that apply.

This was a new question to the 2003 TMA Survey. The 64 TMAs that responded to the questios indicated that they utilized a variety of techniques to recruit board members, as shown in Figure 42. Some of the "other" methods are targeting business leaders of member organization appointments to the board by member organizations, tapping parent organization representatives election by board members and receiving nominations.

Figure 42: Board Recruitment Activities

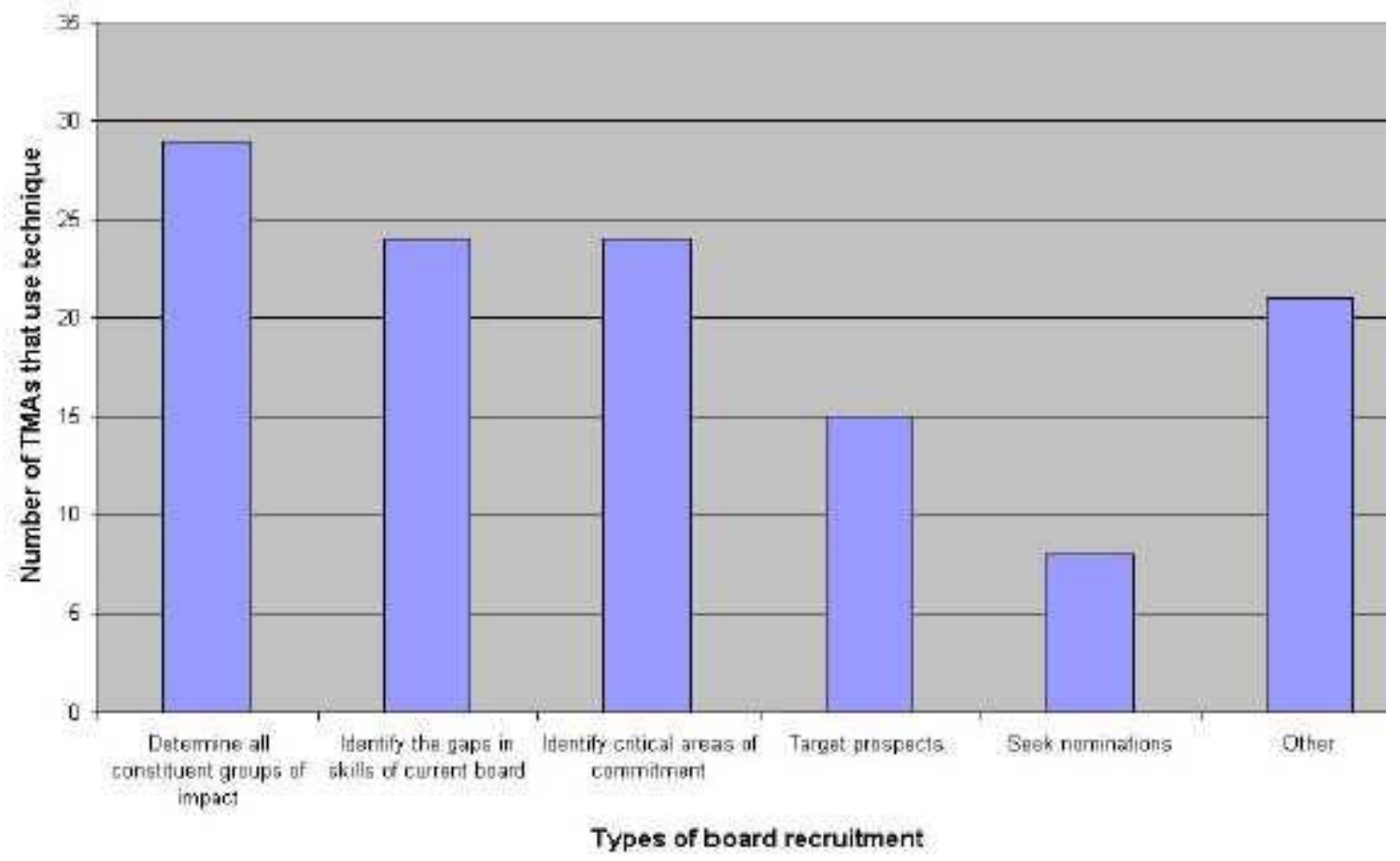

\section{Board Training Activities}

59. How do you provide board training? Check all that apply.

This was a new question in the 2003 TMA Survey. Out of the 96 potential responses, 39 percen indicated that some type of training was provided for their boards. The remaining 61 percent indicated one of the following: 


\section{Transportation Management Association (TMA) Survey}

TMAs provided no training

Board training was inapplicable

The TMA did not respond to the question

According to those TMAs who provide training, 13 percent indicated that their TMA provides new board members with orientation training. Another seven percent of TMAs provide a board member manual only. Another 11 percent provide both orientation training and a board membe manual. The final eight percent indicated using other training formats, such as informat packets, retreats and ongoing training.

\section{Board Member Responsibilities}

60. Which of the following activities are considered responsibilities of board members, either in whole or in part? Check all that apply.

This was a new question to the 2003 TMA Survey. Responsibilities of the board were describec by 64 of the TMAs and are listed in Figure 43.

Figure 43: Board Member Responsibilities

\begin{tabular}{|l|l}
\hline Responsibility of the Board & \% of TMA Boards Filling this Role \\
\hline Financial oversight & 88 \\
\hline Strategic planning & 84 \\
\hline Work plan development & 64 \\
\hline Member recruitment & 59 \\
\hline Financial planning & 43 \\
\hline Other & 17 \\
\hline
\end{tabular}

“Other” included project approval, governance, policy development, human resources oversight policy review and advocacy.

\section{TMA Documents}

61. Which of the following documents does your TMA maintain? Check all that apply.

A comparison of the use of governing documents by TMAs, shown in Figure 44, indica general decrease in the use of these tools. This can be explained by the greater number of TMAs operating informally. The larger percentage of TMAs in 2003 that have a policies and procedures manual is explained by the number of newer informal TMAs whose personnel are under the protection of policies and procedures drafted by a parent organization. But even if we account for the informal TMAs regarding strategic planning and the crafting of by-laws, there is 


\section{Transportation Management Association (TMA) Survey}

still a drop in activity relating to these two documents. Looking at TMAs without strategic plan by budget in 2003, we find that 24 percent of TMAs with budgets greater than $\$ 300,000$ do not have strategic plans. While there is no comparative data for 1993, in 2003, 40 percent of TMAs do not have annual or 2-year work plans.

Figure 44: Comparison of Governing Documents Used_

\begin{tabular}{|l|l|ll}
\hline Type of Governing Document & $\mathbf{1 9 9 3}$ & $\mathbf{1 9 9 8}$ & $\mathbf{2 0 0 3}$ \\
\hline By-laws & $84 \%$ & $63 \%$ & $64 \%$ \\
\hline Mission Statement & $78 \%$ & $94 \%$ & $72 \%$ \\
\hline Objectives & $65 \%$ & $77 \%$ & $54 \%$ \\
\hline Strategic Plan & $55 \%$ & $67 \%$ & $35 \%$ \\
\hline Policies and Procedures Manual & $16 \%$ & $48 \%$ & $26 \%$ \\
\hline Annual or 2-year Work Plan & -- & -- & $60 \%$ \\
\hline
\end{tabular}

\section{Strategic Plan Updates}

62. If your TMA maintains a Strategic Plan, how often does your governing body review and update the plan? Check only one.

Approximately 26 percent of responding TMAs updated their strategic plans once yearly, another 3 percent updated their strategic plans 2 or 3 times per year, and another 5 percent of TMAs completed updates every 5 years. Another 4 percent of TMAs provided miscellaneous answers, such as that they never updated their strategic plan, updated their strategic plan needed, or the process of strategic plan updating has not yet been established. Approximately 2! percent of all TMAs did not respond to the question and 32 percent replied that strategic plan updating did not apply to their TMAs.

\section{Insurance Retained}

\section{Does your TMA retain any of the following insurance? Check all that apply.}

The options listed in the survey included directors and officers insurance, fiduciary liabil insurance and professional liability insurance. In 1993, 43 percent of TMAs had directors and officers insurance, 18 percent had fiduciary liability insurance, and 31 percent had professional liability insurance. In 2003, the figures are roughly the same with 38 percent of TMAs retaininধ directors' and officers' insurance, 22 percent retaining fiduciary liability insurance, and 2 percent retaining professional liability insurance. Also, 31 percent had no insurance and anothe] 10 percent either did not know or provided no answer. This 41 percent corresponds to unincorporated TMAs. The remaining 59 percent had either one type of insurance only (18 


\section{Transportation Management Association (TMA) Survey}

percent) or some combination (41 percent). Among those that had insurance, 15 percent retaine some other type not originally listed. These include:

Commercial crime

Commercial liability

General liability

Workers compensation

Employee dishonesty

Business property

Excess vehicle

Loss of valuable papers

Transit card theft and loss

\section{TMA Committee Types}

64. What type of policy or service committees operate within your TMA? Check all that apply.

In 1993, 75 percent of TMAs had an executive committee and in 1998, this dropped to 62 percent. In 2003, 47 percent of TMAs had an executive committee. Approximately 60 percent of TMAs conducted work through a committee, indicating that there is some decrease in the use of committees to accomplish TMA work. In 2003, TMAs supported from one to five committees, with the exception of one TMA that had ten committees. The number of committees maintained by a TMA is partly a function of the number of board members. For example, a board of three members would not support committees. However, while we slight increases in the number of both voting and non-voting board members, there is a decrease in the number of committees.

The combination of fewer meetings per year and less committee work might indicate that board members are spending less time conducting the work of the TMA. The committee most often employed by TMAs is the executive committee, followed by project specific committees percent). Other committees used by at least 10 percent of all TMAs include budget/finance (20 percent) and membership/recruitment (10 percent), down from 18 percent in 1998. At least one TMA indicated using other committee types listed on the survey, including long range planning, administrative, media/public relations, legal, government affairs/advocacy, personnel/humar resources, publications and convention/annual meeting. Another 11 percent of all respon TMAs wrote in committees not otherwise listed in the survey options. These committe included:

Nominating

Coalitions focused on transportation corridors 


\section{Transportation Management Association (TMA) Survey}

Operations

Special events/programs

ETC network

Transit

Audit

Vanpool

Education

Local initiatives

\section{Legal Counsel Retained}

\section{Does your TMA retain legal counsel?}

In 1993, 69 percent of TMAs had legal counsel, while in 2003, 54 percent of TMAs retain legal counsel. If we remove from consideration the number of TMAs that are more inforn organized, then this percentage jumps to 60\%, which is still less than in 1993.

\section{Relationship with Legal Counsel}

66. If yes, what relationship do you maintain? Check only one.

Figure 45 describes the type of arrangement for legal counsel used by TMAs. It is assume ten years ago, some portion of the volunteer counsel came from board members. It is inte] that while boards have increased slightly in numbers, there has been a decrease in counsel.

Figure 45: Comparison of Legal Counsel Used

\begin{tabular}{|l|l|l}
\hline Legal Counsel Type & $\mathbf{1 9 9 3}$ & $\mathbf{2 0 0 3}$ \\
\hline Attorney on staff & $0 \%$ & $4 \%$ \\
\hline Volunteer counsel & $49 \%$ & $18 \%$ \\
\hline Attorney on retainer & $6 \%$ & -- \\
\hline Attorney on annual retainer with supplement & -- & $3 \%$ \\
\hline Attorney on annual retainer for all services & -- & $3 \%$ \\
\hline Hire per job basis & $23 \%$ & $18 \%$ \\
\hline Other (use counsel of parent) & -- & $6 \%$ \\
\hline
\end{tabular}




\section{Transportation Management Association (TMA) Survey}

\section{Legal Counsel Presence at Board Meetings}

67. Does your TMA require the presence of legal counsel at board meetings?

In both 1993 and 2003, 6 percent of TMAs required the presence of an attorney at meetinধ

\section{Issues Requiring Legal Counsel}

68. What issues, if any, have required legal counsel over the past year? Check all that apply.

In 1993, 39 percent of TMAs reviewed service agreements, 33 percent filed for incorporat and 4 percent provided counsel for lawsuits. In 2003, the percentage of TMAs us counsel to review service agreements stayed the same but the percentage of TMAs using $c$ to file for incorporation dropped to 14\%, mirroring the slowing rate of TMA formation in 1990s and early 2000s as well as an increase in the number of TMAs operating informally number of TMAs using legal counsel to handle lawsuits rose slightly from 4 percent to $6 \mathrm{~F}$ In 2003, TMAs also used legal counsel for tax filing, insurance guidance, and personnel is

\section{Technology-Based Activities}

69. Which of the following technology-based activities or communication strategies does your TMA support? Check all that apply.

Survey responses indicate that 85 percent of TMAs host a website, 82 percent use distribution lists, 47 percent provide on-line ridematching, 41 percent have conducted web surveys and three percent have offered a dial-up bulletin board system. Another four perc TMAs have employed other technology-based activities, including email alerts, online inc programs, and an interactive kiosk. Two percent of all responding TMAs have us technology-based activities and six percent did not answer the question. In 1998, 50 perce TMAs hosted a web site, 19 percent of TMAs used email distribution lists and 29 percent a dial-up bulletin board system. 


\section{Transportation Management Association (TMA) Survey}

\section{Canadian TMAs}

Canadian TMAs participated in the TMA Survey for the first time in 2003. There are eight known TMAs, seven of whom responded to the survey. Three TMAs are located in Vancouver, British Columbia, three more TMAs are located in Montréal, Québec, one TMA is located in Toronto, Ontario and one TMA is located in Halifax, Nova Scotia. Two TMAs are regional or multi-jurisdictional, one TMA is citywide, another TMA represents a corridor, another T] represents a central business district and the final respondent represents an industrial park. The history of TMAs currently operating in Canada has a more recent beginning than that of their U.S. counterparts. The oldest Canadian TMA began in 1995. The majority of Canadian TMAs were formed through the combined efforts of government transportation agencies, employers an developers.

Most operate within a parent organization, such as a business improvement district, a chamber o commerce, or an organization that has a Canadian charitable nonprofit tax status. While the authority for final actions rests with the membership of two TMAs, the authority for other TMA is shared either with government or is held by appointed officials or advisory committees.

Membership is composed of various groups for all TMAs with the percentage of membership composed of the following in descending order of magnitude: government employe businesses, government agencies, residential associations, and developers. The membership of one TMA also includes a university and a union. Based on survey responses, members includes from 7 to 13 members, serving travel markets of as many as 15,000 commuter students. Members are recruited using a range of tactics, with contact from a Board Director anı peer to peer recruitment considered the most successful tactics.

Canadian TMAs offered a broad range of services, with two TMAs providing services to both members and nonmembers while the other four provide services to members only. The mo: frequently offered services include rideshare matching, promotional materials and events. regional advocacy. Canadian TMAs appear to provide more program emphasis uf telecommuting program assistance, car share programs and bicycle programs than do U.S TMAs.

Most Canadian TMAs employ one full-time staff member and one part-time staff membr Executive directors come from a wide range of professions, including the more traditioni backgrounds of transportation planning, public relations and non-profit association management Professional backgrounds that appear more frequently than those for U.S. TMA executivi directors have included teaching and an emphasis on environmental studies. The most frequentl cited range for the executive director salary is $\$ 40,000-\$ 50,000$ USD. Generally half of Canadian TMAs provide medical, dental and vision insurance, and a transportation allowance to 


\section{Transportation Management Association (TMA) Survey}

staff. More than half of the TMAs provide paid holidays and seminars. Less than half of TMAs provide family leave, life insurance, disability insurance and professional me dues. Annual TMA budgets range from less than $\$ 50,000$ to between $\$ 100,000$ and $\$ 150$, Regarding budget breakdown, Canadian respondents generally did not include the cost of within the listed line items. Salary was separated out and listed as the largest budget expe between 40-60 percent of total budget. No TMAs provided shuttles or transit service. Off operations were listed as five to 53 percent of total budget with marketing as the next larg expense, at six to 30 percent of total budget. The majority of funding for Canadian TMAs from government grants. Up to 80 percent of a TMA budget was funded by federal grants one case) but mainly from 50-75 percent came from the provinces and 25 percent were local grants, with the remainder from other sources. Two TMAs used member dues as a minor of income.

Six Canadian TMAs submitted their mission statements. Themes are generally sim mission statements of those of U.S. TMAs. The reduction of greenhouse gases an promotion of health and well-being were additional themes not found elsewhere. 


\section{Transportation Management Association (TMA) Survey}

\section{The Traditional TMA Versus the “Average” TMA of Today: A Summary of Changes}

Survey results indicate that all TMAs differ, by at least one quality, from the "average" aggregated across all responses given by survey participants. But if we were to create a profile of a "traditional" TMA, based upon the most common answers given in the TMA Survey results of 1993, the TMA was either regional, suburban or corridor in scope, serving an averagt 45,800 commuters. The central focus of the TMA was policy leadership, advocacy and service provision. The TMA had 20-80 members mostly composed of business employers. The TMA used contact from the Executive Director and peer-to-peer contact as chief member recrui tactics. The TMA was incorporated with a high degree of organizational administration through the use of governing documents. The TMA held annual meetings, with the board of dir meeting 5-6 times per year. The TMA leased office space and operated on an annual budget of $\$ 149,000$, with dues the greatest income source. The TMA used legal counsel and wou provide an annual financial report to its members but did not conduct a program evaluation. Thi TMA had an executive committee, one paid staff member and did not commonly contract out fo services. The Executive Director had a transportation background and was paid $\$ 42,500$ annually. The TMA did not conduct employee evaluations.

TMAs have changed since 1993. In 1993, while the traditional TMA was either region suburban or corridor in scope, the "average" TMA of 2003, based on collective survey results was either regional, corridor or CBD, but with generally greater diversification and specificatior of service area. In 1993, the TMA served an average of 45,800 commuters while in 2003, the majority of TMAs served travel markets in addition to or other than commuters. The cr focus of the TMA in 1993 was policy leadership, advocacy and service provision, while in 2003 the focus stayed generally the same with the most commonly offered services being promotiona materials and events, rideshare matching, guaranteed ride home and regional/local advoca However, we are seeing a broader range in services offered and TMAs were tailoring servic offerings more to the needs of travel markets. In 1993, the TMA had 20-80 members mostly composed of business employers. In 2003, the typical TMA had less than 40 members with business employers still the leading member group but with a greater diversification of member types. In 1993, the TMA used contact from the Executive Director and peer-to-peer contact as chief member recruiting tactics while in 2003 the vast majority of TMAs used a more varied combination of two or more recruitment tactics. In 1993, the TMA was incorporated with a hig] degree of organizational administration through the use of governing documents. In 2003, the average TMA was incorporated but there were more TMAs operating informally. In 1993, the average TMA held annual meetings, with the board of directors meeting 5-6 times per year. In 2003, a lesser majority of TMAs held annual meetings, with the board of directors meeting on average 4.5 times per year. In 1993, the TMA operated on an annual budget of $\$ 149,000$, with dues the greatest income source. In 2003, the majority of TMAs operated on a budget in the 


\section{Transportation Management Association (TMA) Survey}

median range of $\$ 150,000$ to $\$ 200,000$. A lesser majority of TMAs collected dues with gi reliance on federal grants. In 1993, the traditional TMA used legal counsel and would pro an annual financial report to its members but did not conduct a program evaluation. In 20 lesser majority of TMAs employed legal counsel, a lesser majority provided an annual fin report to their membership, and the majority conducted program evaluations. In 1 ! average TMA had an executive committee, one paid staff member and did not cor contract out for services. In 2003, the majority of TMAs did not have executive committees (although 60 percent of all TMAs used some type of committee) and employed more than paid staff member. Contracting out for various functions was more common. In Executive Director of the traditional TMA had a transportation background and wa $\$ 42,500$ annually. In 2003, the most common Executive Director backgrounds were mark transportation, and non-profit association management, in that order, and were paid an av€ annual salary of $\$ 62,000$. In 1993, the average TMA did not conduct employee evaluations, while in 2003, the majority of TMAs did. 


\section{Transportation Management Association (TMA) Survey}

\section{Observations}

The data contained in the 2003 TMA Survey contains a wealth of information about the organization and function of TMAs. This report has provided comparative information I surveys from previous years as well as results from Canadian TMA surveys. With the exceptior of The Netherlands, transportation management efforts in European nations are implemen through organizational structures different from TMAs as we know them in the United States an Canada. Mobility management services in European nations are generally provided thro individual entities rather than partnerships. Canadian and U.S. TMAs are more similar than the! are different. The main differences are that Canadian TMAs are younger in formation and they rely less on member dues and more on government funding sources than do U.S. TMA: Government employers are primary members of Canadian TMAs. The backgrounds of Canadia TMA executive directors show more teaching and environmental studies while U.S. TM executive directors appear to come more so from marketing backgrounds. Canadian TMAs cite the promotion of health and well-being which is not frequently cited in the missions of TMAs.

In the U.S., at least one TMA is located within 29 states and half of all U.S. TMAs are in one of four states that have strong air quality or land use regulatory environments. Rates of TMA startups peaked around 1993, then decreased, coinciding with the repeal of the federally mandated Employee Commute Options requirements. Since 1998, new TMAs have continued to form but at a lower rate of about four per year. The survey results indicate a net growth in the number of TMAs of less than 5 percent in the United States since 1993.

\section{Observations from 1993 TMA Survey and How TMAs Compare in 2003}

The 1993 TMA Survey provided recommendations about how TMAs could improve. These are listed in Figure 46 below with an assessment of progress made, based on the results of the 2003 TMA Survey. 


\section{Transportation Management Association (TMA) Survey}

Figure 46: Comparison of 1993 Recommendations and Progress Made By 2003

\begin{tabular}{|l|l|l|l}
\hline 1993 Recommendation & Some Progress & Little Progress & Not Kr \\
\hline $\begin{array}{l}\text { 1. Newer TMAs must return to the } \\
\text { fundamentals of association management }\end{array}$ & & $\mathrm{X}$ & \\
\hline 2. Develop dues and non-grant sources & & $\mathrm{X}$ & \\
\hline 3. Provide adequate support staffing & $\mathrm{X}$ & & \\
\hline $\begin{array}{l}\text { 4. Support staff should have benefit of } \\
\text { regular reviews }\end{array}$ & & & $\mathrm{X}$ \\
\hline $\begin{array}{l}\text { 5. Executive directors should take the time } \\
\text { to renew and recharge their creativity and } \\
\text { sense of purpose }\end{array}$ & & $\mathrm{X}$ \\
\hline $\begin{array}{l}\text { 6. Do strategic planning to maintain a focus } \\
\text { on what makes your TMA unique }\end{array}$ & & $\mathrm{X}$ & \\
\hline $\begin{array}{l}\text { 7. Create support systems and allies for } \\
\text { your TMA }\end{array}$ & & & $\mathrm{X}$ \\
\hline $\begin{array}{l}\text { 8. Do the legwork while sometimes } \\
\text { allowing others to take the credit }\end{array}$ & & $\mathrm{X}$ \\
\hline 9. Make use of new technologies & $\mathrm{X}$ & & \\
\hline $\begin{array}{l}\text { 10. Develop adequate compensation and } \\
\text { benefit packages for TMA staff }\end{array}$ & $\mathrm{X}$ & & \\
\hline
\end{tabular}

Regarding a return to the fundamentals of association management, the 2003 TMA results indicate a trend toward more TMAs operating informally. This is not nece negative trend and may simply indicate that different TMAs operate best under dif organizational structures. However, survey results also indicate a lessening use of documents, such as objectives, strategic plans and annual work plans. Informally ( TMAs can certainly use these tools regardless of their incorporation status. Decreased us€ governing documents is a negative trend. Use of such tools allows the TMA to deliberate] and map out its future, based upon careful consideration of service area characteris evaluation results.

TMAs have not made progress in developing dues and non-grant sources. Instead, the us€ dues has decreased and reliance upon grant funds has increased. In 1993, 20\% of respond obtained $100 \%$ of their funding from dues. Dues made up $47 \%$ of average total revenue. 2003, 5 percent of respondents obtained 100 percent funding from dues and dues made up percent of average total revenue. 


\section{Transportation Management Association (TMA) Survey}

The percentage of all TMAs who receive funds from these sources is as follows:

$\begin{array}{ll}56 \% & \text { Member dues } \\ 48 \% & \text { Federal grants } \\ 28 \% & \text { Local grants } \\ 27 \% & \text { State grants }\end{array}$

The decrease in revenues from member dues is likely associated with the corresponding $d$, in business employers and developers as member groups, who would pay higher dues fees fee rates established for other member groups (i.e., non-profits). The income source that a to make up the difference is government funding. This is not a positive sign for TMAs be government as a TMA “customer" represents the general public, which is a far less specifi more nebulous target market than developers and business owners. If a business $\mathrm{r}$ withdraws from membership, the TMA loses the income derived from the dues of one me] But with government as a member, a far too large proportion of a TMA budget (in the forr large grant) is controlled by one or a few entities and the withdrawal of grant funds could disaster for the TMA. For example, the effective work of many TMAs that have assisted 1 to attain federal air quality standards may mean their doom as TMAs become less receive Congestion Mitigation and Air Quality grants. TMAs have also not made progres: strategic planning. Only 35 percent of TMAs developed strategic plans in 2003, as compa 45 percent in 1993.

TMAs have made progress in providing support staffing, as evidenced by 32 percent of TI with more than three persons on their staff in 2003, as compared to 9 percent of TMAs with more than 3 persons in 1993. TMAs have made progress in the adoption of new technolo particularly in the increased use of web sites and email distribution lists since 1993. Gene TMAs have made progress with providing compensation and benefit packages. More typ insurance coverage have been made available to TMA staff over the years. It also appears more TMAs are offering a greater variety of benefits, including more retirement benefits. the use of formally adopted personnel policies and annual employee evaluations has increi Four additional recommendations from 1993 do not correspond with data collected surveys. New questions aimed at measuring such progress might be considered for inclus: future surveys.

Additionally, there were recommendations from the 1993 TMA Survey regarding future ri TMAs. These include those below as well as an assessment of the use 0 : recommendations. 


\section{Transportation Management Association (TMA) Survey}

1. Provide services that link information to appropriate markets, such as advanced travele information services (ATIS). The 2003 TMA Survey yielded no responses for Question 16 regarding services offered, which relate to linking information. This does not necessarily mean that no TMAs do this. This role may be accomplished as part of other services, such "Promotional materials/newsletters" (offered by 88 percent of all TMAs); however, it might be useful to explicitly ask TMAs in the future if they conduct activities that aim to link information to appropriate markets, including ATIS.

2. Conduct data collection/data validation. The 2003 TMA Survey yielded no respons indicating that TMAs conducted data collection, except for activities relating to program/service evaluation (81 percent). Other types of data collection tended to be conducted by contracted consultants (studies/surveys, as indicated by a small number of TMAs in answer to question 22) and that may be the most practical solution in many cases.

3. Provide services that promote community livability. A wide interpretation of such service might include those that some TMAs indicated, such as pedestrian amenity review, livab community camps, and shuttle service operation. It is noted that fewer TMAs are now conducting site design assistance than in 1998 (38 percent in 2003, 51 percent in 1998).

4. Communicate business and community needs to policymakers and communicate public policy issues to businesses and the community. This may be interpreted as the high number of TMAs that indicated providing regional/local advocacy (74 percent in 2003), although advocacy and communication are not exactly the same thing. It could be that many TMAs foster this twoway communication in the course of their work without having articulated it as such.

5. Probe new markets for transit. This may be reflected in the numbers of TMAs that provide direct shuttle service operation (29 percent), shuttle/local transit provision (52 percent) ar subsidized transit passes (53 percent). Another interpretation of this recommendation might be activities relating to assisting the local transit agency to reach new markets.

\section{Indications of Increasing Diversification}

As the 1998 TMA Survey findings noted and the 2003 TMA Survey findings confirm, TMAs ar diverse in characteristics and operations. The 2003 TMA Survey results indicated trends towarc increasing diversification. It was clearly challenging for survey respondents to accurately describe their TMAs within the constraints of the answer options, even after the 2003 Survey was expanded to cover a greater range of answers. However, the apparent trend toward increasing diversity of TMAs as characterized by the 2003 TMA Survey may be overstated and not necessarily reflect true changes in TMAs over the past ten years. This is due to th inclusiveness of the most recent definition of a TMA in the TMA Handbook, so that more diverse 


\section{Transportation Management Association (TMA) Survey}

organizations considering themselves TMAs have responded who otherwise might $\mathrm{n}$ Also, the expansion of answer options in the 2003 TMA Survey may appear to indicate ch and increasing diversity of TMAs over the years, when in reality, the responses $\mathrm{m}$ closely specify the nature of the TMA as it has been all along.

The survey results show variety in the definition of TMA service areas, with 28 percent of identifying themselves as either specialized activity center or something "other" tha traditional service area types. These others include countywide, an industrial park, a rural a single employer, half a city, a master planned community, an area larger than a smaller than citywide, a bi-county low density research and development park, a national ] and a statewide TMA.

Not only is there an enlarging range in size of memberships, but TMAs define what it mec be a member in at least five different ways. Overall TMA membership size appeal decreased in the last 10 years with 65 percent of all TMAs having membership of 40 or le: However, another 23 percent of all TMAs have memberships of 81 members or higher. T memberships that include members of a parent organization can have memberships thousands, while TMAs whose boards of directors are the members may have less members.

Employers remain the greatest influence in TMA formation but the growing variety of inv organizational types indicates the importance of partnerships. There were 18 other groups cited by TMAs as playing instrumental roles. Among many reasons for TMA forn traffic congestion ranked the highest; however, there were at least nine other common entr The central focus of TMAs has not changed in the last ten years, with the most common $n$ theme to improve travel, mobility and accessibility and to reduce traffic congestion; howe eleven other common mission themes were identified.

In 2003, business employers remained the most highly represented group within a TMA b lesser majority than in 1993 . This coincides with an increase and broadening dive member types, such as government partners, property owners, non-profit associations, resi or community associations and educational institutions. Some of these groups have less fi resources and political clout than business employers.

In 2003, the average TMA covered an area that contained an average of 49,100 commuters, which is slightly higher than five years ago. However, 58 percent of all respondents indic that their TMAs serve travel markets in addition to or other than commuters. These incluc percent serving students, 40 percent serving residents, 29 percent serving visitors, and $5 \mathrm{pr}$ serving other travel markets. 


\section{Transportation Management Association (TMA) Survey}

Since 1998, a decreasing proportion of TMAs are now offering ETC training, regional/lc advocacy, site design assistance, parking services, promotional events and trip reduction $\mathrm{F}$ preparation. Since 1998, a growing proportion of TMAs are now offering shuttle/local transit provision, vanpool subsidies and transit pass subsidies, in addition to a variety of creative servic concepts. This appears to indicate that while several traditional member services are be offered less by TMAs, a greater variety of services are being offered across all TMAs, which may be an indication that TMAs are tailoring the selection of services to meet the needs of their travel markets.

\section{Indications of Decreased Activity by Memberships and Boards}

Looking across the trends in data, Figure 47 summarizes increases and decreases in vari activities. The following text provides some brief detail about these trends.

Figure 47: Trends in TMA Activity Levels

\begin{tabular}{|c|c|}
\hline Decreases in Activity & Increases in Activity \\
\hline 20 Membership size & 20 Board size \\
\hline 20 Volunteer staffing & 20) Paid staffing \\
\hline 2๑ Peer-to-peer member recruiting & 2๑ Board chair recruiting \\
\hline 2๑ Annual meetings & 20 Use of personnel policy document: \\
\hline 20 Board meetings & 20 Use of employee evaluations \\
\hline 20 Committee work & 20. Use of program/services evaluatio] \\
\hline $\begin{array}{l}\text { 20 Contracts with vendors for TMA } \\
\text { staffing }\end{array}$ & $\begin{array}{l}\text { 20 Contracts with vendors for se } \\
\text { delivery }\end{array}$ \\
\hline 2๑ Use of dues & \\
\hline 2๑ Strategic planning & \\
\hline 20 Use of governing documents & \\
\hline 20 Annual audit & \\
\hline 20 Annual financial report & \\
\hline 20 TMA incorporation & \\
\hline 20 Use of volunteer legal counsel & \\
\hline
\end{tabular}

While TMAs that are part of parent organizations or community improvement districts can have memberships in the hundreds and even thousands, membership size across all TMAs appears to be decreasing overall.

A comparison of the numbers of staff employed by TMAs in 1993 and in 2003 indicated that TMAs today have more paid personnel and rely less on volunteers. There is an upward trend in TMAs contracting out more for services, from 25\% in 1993 to 59\% in 2003. Perhaps this reflects the understanding that generally small TMA staffs function 


\section{Transportation Management Association (TMA) Survey}

better if they concentrate on what they do best and not attempt to do everything themselves as their menus of services expand.

While peer-to-peer recruitment of members decreased by 24 percent in the past ten years, contact from the Board Chair to recruit members increased by 27 percent.

Figure 48: Use of Recruitment Tactic by_Percentage of_TMAs

\begin{tabular}{|lll|}
\hline Recruitment Tactic & $\mathbf{1 9 9 3}$ & $\mathbf{2 0 0 3}$ \\
\hline Peer-to-peer contact & $66 \%$ & $42 \%$ \\
\hline Contact from Board Chair & $25 \%$ & $52 \%$ \\
\hline
\end{tabular}

In 2003, 56 percent of TMAs were incorporated, down from 78 percent in 1993. In 1993, the TMA was incorporated with a high degree of organizational administration through the use of governing documents. Over the past ten years, TMAs appear to be moving toward less formalized organizational structures. This may be due to the desire demonstrate results quickly through programs and services by sidestepping the eff involved in setting up the administrative structure of an independent non-profit. It may also be due to a greater reliance on government funding, which may enable TM. concentrate immediately on service provision rather than organizational administration.

In 2003, 59 percent of all TMAs conducted an annual audit, down from 75 percent in 1993.

In 2003, 54 percent of TMAs provided an annual financial report, down from 66 percent in 1993.

1n 2003, 65 percent of TMA held annual meetings, down from 80 percent in 1993.

The average number of board members has increased from 12 in 1998 to 15 in 2003. The number of non-voting board members has also increased from 1 in 1998 to five in 2003.

In 2003, TMA boards met on average 4.5 times per year, down from 5.6 times per year in 1993.

While 84 percent of TMA executive directors consider strategic planning as a board role, just 35 percent of TMAs use strategic plans, down from 55 percent in 1993.

The number of TMAs with an executive committee decreased from 75 percent in 1993 to 47 percent in 2003. Approximately 60 percent of TMAs conducted work through some 


\section{Transportation Management Association (TMA) Survey}

type of committee, indicating that there is some decrease in the use of committees to accomplish TMA work.

In 1993, 69 percent of TMAs had legal counsel, while in 2003, 54 percent of TMAs retained legal counsel. The amount of volunteer counsel decreased from 49 percent in 1993 to 18 percent in 2003.

In 1993, less than 50 percent of TMAs conducted program evaluations. In 2003, 81 percent had conducted program evaluation.

While there is no comparative data from previous surveys, the data in 2003 show that:

Approximately 40 percent of TMAs do not have annual or 2-year work plans.

Only 39 percent of TMAs provide some type of training for their boards.

Only five percent of TMAs have set a maximum number of terms for board officers, of either one or two terms. This may be an indication of how difficult it is to find good leadership.

Considering each decreasing trend alone, it may not necessarily mean anything to worry about. For example, a decrease in TMA incorporation is not necessarily a negative indicator of health of TMAs. As a matter of fact, the data from 2003 show a slight increase in the authority of the membership only determining final actions of the TMA. This would be an indicator of increased autonomy of TMAs. Lack of incorporation does not preclude activities such c strategic planning and financial reporting. However, looking at these trends together appears to indicate a decrease in activity of the general membership of the TMA, with this member activity being replaced by increased involvement of board members. As the number of TMAs i executive committees has shrunk from 75 percent to 47 percent, even board mem involvement may also be decreasing. A reliance on a more permanent paid staff, rather than a previous greater reliance on contracted staff, might indicate that TMAs depend more upon the staff to maintain a continuity of mission, focus and expertise. This does appear worrisome, as more work is being done by fewer people, especially if board members are not receivin benefits of initial training as well as enjoying the knowledge that their term of service has an enc to it. These are not positive signs of change for TMAs collectively, and may point to necessity of TMAs to look closely at the service needs of the membership to determine ways to revitalize the appeal and role of the TMA in the business community.

In the later 1980's and early 1990's, there may have been a higher degree of anticipation over th potential of TMAs, as an organizational structure that can deliver resolution to transportation issues. In 2003, as the relative newness of the TMA concept has matured, a sense of reality has set in that while TMAs can and are effective organizational structures for address 


\section{Transportation Management Association (TMA) Survey}

transportation issues, many of the kinds of problems that TMAs address do not go overnight, if ever. Positive gains in traffic congestion reduction may be offset by growth. effectiveness is commensurate with the degree of ongoing commitment and time that part willing to give to chronic issues. TMAs have larger permanent staffs than they used to. V this is a positive sign that TMAs have more stable and ample resources to carry c missions, it also makes it easier for a tired or uninspired TMA board to lean more upon th to "carry the torch". Within a TMA service area there may be only a small number of TM "champions" among the membership that can ably lead the organization at any one time.

Is a suspected decrease in TMA member activity necessarily a negative trend? What the 1 Survey does not ask those surveyed is for an indication of the degree of success c member and customer satisfaction, or trends in improvement of programs. If mem satisfaction is high, then lessened activity could be an indicator of issue resolution. Each ? must answer this for itself. 


\section{Transportation Management Association (TMA) Survey}

\section{Recommendations}

This section includes recommendations for actions that TMAs should consider to improv operations and performance.

\section{Develop Roles and Services That Members Value}

The biggest issue for TMAs continues to be developing and maintaining a role in the communit: and a program of services that remains fresh, addresses the needs of the membership an compels them to remain actively involved. Because of growing diversity among members who may perceive needs differently, limited resources, and programmatic constraints placed uf TMAs by the dictates of funding sources, it is crucial for TMAs to engage the Board in strategic planning. It is also critical that TMAs prepare annual or two-year work plans to keep activities and efforts on track. Feed the results from program and service evaluations back into $\mathrm{t}$ planning activities. The information contained in the 2001 TMA Handbook provides usef guidance. Conduct market research to match targeted markets with services tailored to 1 needs. Sophisticated mapping software programs at decreasing prices continue to be developed for "microtargeting" areas for services, which can put to use over 100 population variables that describe economic characteristics.

\section{Seek Alternative Income Sources}

Once the first recommendation is accomplished, then funding sometimes falls into place. Usually TMAs must seek new funding sources constantly. Before we turn attention away from government grants, it is worthwhile to consider other sources of government funds based upon activities of the TMA. For example, there may be a strong role for TMAs in an aggressive maintenance of traffic campaign launched before and during major highway reconstructio projects. Departments of transportation might consider funding such activity from sources othel than the traditional pots of money reserved for funding TMAs.

Beyond member dues and government grants, TMAs have secured funding through in-kil donations, service contracts, fees for services, developer funding agreements and business improvement districts or community financing districts. A full quarter of TMA Survey respondents secure funding from "other" sources in addition to the ones above. These 1 included transit fares, taxes, municipal sponsors, parent organizations, vanpool reven promotional events, parking fees, organization investments, and foundation grants, discuss more here.

Private foundations will not grant funds to 501(c)(4) or 501(c)(6) organizations because types of organizations serve only designated members and they can collect dues. Private 


\section{Transportation Management Association (TMA) Survey}

foundations will more likely consider requests from 501(c)(3) organizations because this type of organization does not collect dues and is expected to serve the general public. Foundat interested in funding TMAs are few but possible to find. For example, the International Counci] for Local Environmental Initiatives funded the "Orangecycle” program of the Tampa Downtowı Partnership several years ago (http://www.iclei.org).

If TMAs are trying to find funding for continuation of operations year after year, it is even more unlikely to find a private funder; however, if a TMA wants to do some kind of special project that has an end date, like a pilot program to try out a new service, or something that has a tangible useful end product, such as a parking map, it is more possible to find a funding source, especially if it is not more than about $\$ 15,000$. Based upon the interests of a particular foundation, the project must be pitched properly to convince funders that the project wo further the mission of the foundation and the visibility of the foundation or its cause. The best approach to finding private sector funding is to look at your entire budget and program activities and see how you can "cut the pie" so that those items that might fall within the interests of a foundation grant can be identified and segmented apart from the rest of your budget. I possible that there are specific services, projects, or products that your TMA is already doing thi could be of interest to a private sector funder. The funder might not have to be a foundation; it could be one of your larger businesses or employers in your service area.

An important trap to avoid is going after a grant just for the sake of its availability by tailoring your program to meet the requirements of the funders. Instead, it is better to develop programs that provide the best services to your members, then see if there are any funding possibilities tha would fit what you already intend to do. For foundation grants, there might be deadlines $f_{\text {, }}$ proposal submittals, reporting requirements and possibly the requirement of a matching grant. I the grant is for just a few thousand dollars, the obstacle course of the proposal process, uncertainty of a final award, and all the paperwork required after winning a grant might not be worth the bother.

An idea that is currently receiving some discussion is the social enterprise model. It involves non-profit organizations developing and running for-profit businesses, the revenues of which are turned back toward funding the mission of the non-profit. This is to diversify income and make the non-profit self-supporting and less reliant on government handouts. One element of this is th use of the "internal assets" of the non-profit to sell as a business. Often, examples of assets of non-profit organizations include excess space to rent, labor force availability, and excess kitcher capacity. What are the internal assets of your TMA? For example, one TMA program in San Luis Obispo once "sold" the use of their shuttle vehicles during off-peak times to various groups such as retirement communities. If a TMA has a geographic information system, this resource and skills could be used to generate mapping for economic development and site planni Some transit agencies make maintenance services available. Here are a few links below to read 


\section{Transportation Management Association (TMA) Survey}

more about this idea. The downside is that a TMA would likely have to pay unrelated busi income tax (UBIT) and there is some possibility that running a for-profit business could tr tax status.

http://www.se-alliance.org/

http://www.communitywealth.com/Powering\%20Social\%20Change.pdf

\section{Find Leaders in the Community}

TMAs must scout for leaders in the community. TMAs are vying for able leaders competition with a variety of other business and service organizations. Leaders ar people already involved in many civic activities dealing with issues of immediate urgency as hunger in the community. Some leaders don't consider the possibility of serving on a 1 board unless asked. Future TMA leaders develop their potential over time and be] opportunities provided through TMA involvement. TMAs must emphasize such be: might be helpful to tap into programs local to your area that are similar to Leades Hillsborough (http://www.leadershiphillsborough.com/) in Florida. Participants of s programs are able individuals that might be looking for a worthwhile cause on which to fo their energy.

Another kind of leadership comes from the bottom up: employees, commuters and residen are willing to assertively voice their transportation needs to employers and transpor providers and policy makers. Businesses listen to their employees. Policy makers listen t constituents. Such citizen leaders first need the information that gives them the la perspective on sustainable mobility alternatives. Secondly, they need encouragemen guidance on how to speak effectively about it, such as how to initiate an internal meeting to discuss a pilot program for flex time or telecommuting. Other methods of spea up include writing letters to newspaper editors and local elected leaders and participation c citizen advisory committee to the local government. These activities require knowledge, $s$ and the strategic timing and placement of their efforts. Only a TMA executive director mi a handle on all these elements at once. Traditionally, this effort has been through the culti of Employee Transportation Coordinators. The 2003 TMA Survey results show thi training by TMAs has been on the decrease since 1998. Some current ongoing research ol topic of institutional culture of the work site suggests that many ETCs have experienced a size-fits-all” ETC training format. ETCs are convinced that trainers do not understand the of their work sites and that the strategies offered would never work under their $\mathrm{cu}$ employment conditions. ${ }^{4}$ A revamping of the expected role and training of ETCs might be

\footnotetext{
${ }^{4}$ National Center for Transit Research. Commuter Choice Program Case Study Development and Analysis. This ongoing research is being prepared with funds from the Federal Transit Administration, under the sponsorship of the
} 


\section{Transportation Management Association (TMA) Survey}

order. Such reconsideration would investigate and develop unconventional, strategic and tailored efforts instead of the more traditional blanket approach we are familiar with.

\section{Provide Board Officer Training and Term Limits}

After bringing in new board leadership, TMAs should provide board member traini helps board members grasp the importance of their task and the possibilities for cc change that they can inspire and set in motion, given the proper tools and skills. cultivating avenues for identifying future potential leaders, term limits for board officers $\mathrm{s}$ be provided. This provides officers the assurance that they can make a graceful exit after a productive term or two of service. It "gives permission" to new potential leaders to express interest in a board officer role and sets a tone that the TMA thrives on fresh perspectives a active participation of many.

\section{Serve on the MPO Board}

This was cited in the 1993 TMA Survey and should be emphasized again. Work creation of a seat on the MPO Board or on their Technical Coordinating Committe representative could be from a TMA or regional commuter assistance program. Tl mobility management and TDM strategies a chance at being applied from the very beginn plan and project development, not as a band aid or afterthought, but as a fully fur integrated strategy into the transportation planning process.

\section{Seek Assistance from Available Resources}

TMA staff and board members are encouraged to seek assistance using resources a through ACT, such as professional development workshops sponsored by the TDM Institu through other ACT Councils. There are many technical assistance providers, such National TDM and Telework Clearinghouse at http://www.nctr.usf.edu/clearinghouse/ as we programs like the Florida Commuter Choice Certificate Program http://www.cutr.usf.e which is open to TDM professionals outside Florida. The TMA Council and TDN should consider providing more workshops for ACT members, perhaps through netconfer to minimize travel costs to participants. Topic areas should include work plan der strategic planning, TMA board development, program evaluation and how to feed $\mathrm{t}$ back into next year's planning cycle, as well as detailed guidance in pursuing various func sources.

Florida Department of Transportation. Prepared by the Center for Urban Transportation Research, University of South Florida, Tampa. 


\section{Appendix A: List of Participating TMAs}




\section{Transportation Management Association (TMA) Survey}

\section{List of Participating TMAs}

\begin{tabular}{|c|c|c|}
\hline 128 Business Council & connor@128bc.com & www.128bc.com \\
\hline 50 Corridor Transportation Management Association & rebecca@50corridortma.org & www.50corridortma.org \\
\hline Airport Corridor Transportation Association (ACTA) & manion@acta-pgh.org & www.acta-pgh.org \\
\hline Anaheim Transportation Network & Ismith@atnetwork.org & www.atnetwork.org \\
\hline $\begin{array}{l}\text { Artery Business Committee }(\mathrm{ABC}) \text { Transportation Management } \\
\text { Association }\end{array}$ & dstraus@abctma.com & www.abctma.com \\
\hline Better Baymeadows Incorporated & v.evans@baymeadowsroad.com & www.baymeadowsroad.com \\
\hline $\begin{array}{l}\text { Biltmore Area Transportation Coordinators Alliance } \\
\text { \%Valley Metro RPTA }\end{array}$ & sday@valleymetro.org & www.valleymetro.org \\
\hline Black Creek Regional Transportation Management Association & janetlo@bcrtma.org & http://www.bcrtma.org \\
\hline $\begin{array}{l}\text { Buckhead Area Transportation Management Association } \\
\text { (BATMA) }\end{array}$ & denise@batma.org & www.batma.org \\
\hline Bucks County Transportation Management Association & wrickett@buckscountytma.org & www.buckscountytma.org \\
\hline $\begin{array}{l}\text { Campus Area Transportation Management Association } \\
\text { (CATMA) }\end{array}$ & catma@uvm.edu & http://www.uvm.edu \\
\hline Central Corridor TCA & bhaldane@valleymetro.org & www.valleymetro.org \\
\hline Central Dallas Transportation Management Association & delvalle@downtowndallas.org & \\
\hline Central Hampton Roads Management Association (CENTRAN) & dawnreed@cox.net & \\
\hline Centre de gestion des deplacements de l'Est (Est TMA) & cgdinfo@sodec.qc.ca & www.sodec.qc.ca/cgd \\
\hline $\begin{array}{l}\text { Centre de gestion des deplacements Saint-Laurent } \\
\text { (Saint-Laurent TMA) }\end{array}$ & $\begin{array}{l}\text { beaudoin.claudine@ville.saint- } \\
\underline{\text { laurent.qc.ca }}\end{array}$ & www.saintlaurent.ville.montreal. \\
\hline Chandler/Gilbert/Attnatuicee & bhaldane@valleymetro.org & www.valleymetro.org \\
\hline Charles River Transportation Management Association & coin1@mit.edu & http://www.masscommute.com/ \\
\hline Charlotte Center City Partners & mquinn@charlottecentercity.org & www.charlottecentercity.org \\
\hline $\begin{array}{l}\text { Clackamas Regional Center Transportation Management } \\
\text { Association }\end{array}$ & crc-tma@yourchamber.com & www.crc-tma.com \\
\hline Clifton Corridor TMA & bdshaw@emory.edu & www.cctma.com \\
\hline CobbRides & info@cobbrides.com & www.cobbrides.com \\
\hline Commuter Challenge & $\begin{array}{l}\text { hengelbrecht@commuterchallenge.0 } \\
\text { rg }\end{array}$ & www.commuterchallenge.org \\
\hline Commuter Club & mrivers@commuterclub.com & www.commuterclub.com \\
\hline Commuter Connections & nramfos@mwcog.org & www.commuterconnections.org \\
\hline CommuteWorks - MASCO & mmarantz@masco.harvard.edu & www.masco.org/commuteworks \\
\hline Downtown Denver Partnership, Inc. & brendon@downtowndenver.com & www.downtowndenver.com \\
\hline $\begin{array}{l}\text { Downtown Fort Lauderdale Transportation Management } \\
\text { Association (DFLTMA) }\end{array}$ & dfltma@fdn.com & www.citycruiser.org \\
\hline Downtown in Motion/Central Houston, Inc. & Laura@centralhouston.org & www.centralhouston.com \\
\hline $\begin{array}{l}\text { Downtown Minneapolis Transportation Management } \\
\text { Organization }\end{array}$ & twernecke@qwest.net & www.mplstmo.org \\
\hline Duwamish Transportation Management Association & dqmic@gwest.net & \\
\hline Ecology Action Centre & trax@istar.ca & http://www.trax.ns.ca/who/who- \\
\hline Emeryville Transportation Management Association & wlspr@aol.com & www.emerygoround.com \\
\hline Glendale Transportation Management Association & glendaletma@earthlink.net & www.glendaletma.org \\
\hline $\begin{array}{l}\text { Grand Avenue Transportation Coordinators Alliance } \\
\% \text { Valley Metro RPTA }\end{array}$ & Iduarte@valleymetro.org & www.valleymetro.org \\
\hline
\end{tabular}




\section{Transportation Management Association (TMA) Survey}

\begin{tabular}{|c|c|c|}
\hline Greater Des Moines Transportation Management Association & tmowry@avoidtherush.org & www.avoidtherush.org \\
\hline Greater Mercer Transportation Management Association & sandra.brillhart@verizon.net & www.gmtma.org \\
\hline Greater Redmond Transportation Management Association & iresha@grtma.org & www.grtma.org \\
\hline $\begin{array}{l}\text { Greater Valley Forge Transportation Management Association } \\
\text { (GVFTMA) }\end{array}$ & pquinn@libertynet.org & www.gvftma.com \\
\hline Hacienda Business Park & james@hacienda.org & http://www.haciendaBusines \\
\hline $\begin{array}{l}\text { Hartsfield Area Transportation Management Association } \\
\text { (HATMA) }\end{array}$ & cheryle@hatma.org & http://www.hatma.org/defaul \\
\hline Hunterdon Area Rural Transit (HART) & tara@hart-tma.com & http://www.hart-tma.com/ma \\
\hline I-494 Corridor Commission & vanhattum494@yahoo.com & www.494corridor.org \\
\hline Junction Transportation Management Association & sfranzeen@wyeth.com & www.masscommute.com/tmas/j \\
\hline LANCO TMS & tmartin@Icci.com & www.lancaster-chamber.com \\
\hline Leeward Oahu Transportation Management Association & lotma@lava.net & www.lotma.org \\
\hline LINK & link@linkinfo.org & www.linkinfo.org \\
\hline Lloyd District Transportation Management Association & mail@Idtma.com & www.ldtma.com \\
\hline $\begin{array}{l}\text { Logan Airport Employee Transportation Management } \\
\text { Association }\end{array}$ & logantma@aol.com & http://www.masscommute.com \\
\hline Mesa Transportation Management Association & achalmers@valleymetro.org & \\
\hline Miami Beach Transportation Management Association & mbtma@earthlink.net & na \\
\hline Midway Transportation Management Organization & rstark@universityunited.com & http://www.universityunited.c \\
\hline Moffett Park \& Business Transportation Association & gundersonmptma@hotmail.com & www.mpbta.org \\
\hline Traffic Solutions & kepperson@sbcag.org & www.trafficsolutions.info \\
\hline New North Transportation Alliance & sobush@cutr.usf.edu & http://www.newnorthalliance.orc \\
\hline $\begin{array}{l}\text { North Black Canyon Transportation Coordinators Alliance } \\
\text { \%Valley Metro RPTA }\end{array}$ & sday@valleymetro.org & www.valleymetro.org \\
\hline $\begin{array}{l}\text { North East Valley Transportation Coordinators Alliance \%Valley } \\
\text { Metro RPTA }\end{array}$ & ischulte@valleymetro.org & www.valleymetro.org \\
\hline North Natomas Transportation Management Association & nntma@inreach.com & http://www.nntma.org \\
\hline $\begin{array}{l}\text { Northwest Valley Transportation Coordinators Alliance \%Valley } \\
\text { Metro RPTA }\end{array}$ & Iduarte@valleymetro.org & www.valleymetro.org \\
\hline NTTN & achalmers@valleymetro.org & \\
\hline Oakland Transportation Management Association (OTMA) & mrainey@otma-pgh.org & www.otma-pgh.org \\
\hline Overland Park Transportation Management Association & ipope@optma.org & www.optma.org \\
\hline $\begin{array}{l}\text { Papage Area Transportation Coordinators Alliance \%Valley } \\
\text { Metro RPTA }\end{array}$ & Iduarte@valleymetro.org & www.valleymetro.org \\
\hline Papago Park Center Transportation Management Association & achalmers@valleymetro.org & \\
\hline $\begin{array}{l}\text { Pasadena Transportation Management Association M/S 310- } \\
108 \mathrm{~A}\end{array}$ & john.miranda@jpl.nasa.gov & \\
\hline Perimeter Transportation Coalition & david@perimetergo.org & www.perimetergo.org \\
\hline Potomac \& Rappahannock Transportation Commission & aharf@omniride.com & www.omniride.com \\
\hline Prairie Stone Transportation Management Association & barbarahayskar@ameritech.net & \\
\hline Ride-On Transportation Management Association & robyn@ride-on.org & www.ride-on.org \\
\hline River Road Transportation Management Association & A.Leary@worldnet.att.net & http://www.masscommute.cc \\
\hline Route 9 Transportation Management Association & rideshare@admin.umass.edu & http://www-parking.admin.un \\
\hline $\begin{array}{l}\text { Saint Petersburg Downtown Partnership Transportation } \\
\text { Management Organization }\end{array}$ & eric@stpetepartnership.org & www.stpeteparnership.com \\
\hline
\end{tabular}




\section{Transportation Management Association (TMA) Survey}

\begin{tabular}{|c|c|c|}
\hline San Francisco International Airport Commission & elizabeth.mingle@flysfo.com & www.flysfo.com \\
\hline Seatac Transportation Partnership & desmond@ci.seatac.wa.us & $\underline{\text { www.seatac.wa.us }}$ \\
\hline $\begin{array}{l}\text { Sky Harbor Transportation Coordinators Alliance \%valley } \\
\text { Metro RPTA }\end{array}$ & ischulte@valleymetro.org & www.valleymetro.org \\
\hline SmartCommute & bunch@rtp.org & www.smartgrowth.org \\
\hline South Boston Seaport Transportation Management Association & kelly.mchugh@fmr.com & www.seaporttma.org \\
\hline South Florida Education Center (SFECTMA) & sfectma@yahoo.com & www.sfec.org \\
\hline South Natomas Transportation Management Association & southnatomastma@aol.com & www.southnatomastma.org \\
\hline Stapleton Area Transportation Management Association & amalpiede@stapletoncorp.com & \\
\hline Swan Island Transportation Management Association & sitma@teleport.com & www.swanislandtma.org \\
\hline $\begin{array}{l}\text { Tampa Downtown Partnership Transportation Management } \\
\text { Organization }\end{array}$ & simonresrc@aol.com & www.tampasdowntown.com \\
\hline $\begin{array}{l}\text { The Partnership Transportation Management Association of } \\
\text { Montgomery County }\end{array}$ & execdir@ptma-mc.org & www.ptma.org \\
\hline The Presidio Trust & gregstempson@yahoo.com & www.presidiotrust.gov \\
\hline $\begin{array}{l}\text { The Rideshare Company (Greater Hartford Ridesharing } \\
\text { Corporation) }\end{array}$ & jcoleman@rideshare.com & www.rideshare.com \\
\hline TranSComm at Boston University Medical Center & maureenlacey@bmc.org & http://www.transcomm.org/ \\
\hline $\begin{array}{l}\text { Transportation Action Partnership of North Bethesda and } \\
\text { Rockville, Inc. }\end{array}$ & nbtmd@erols.com & www.nbtc.org \\
\hline Transportation Management Association Group & dianejdavidson@msn.com & www.tmagroup.org \\
\hline Transportation Management Association of Chester County & mike@tmacc.org & www.tmacc.org \\
\hline Transportation Management Association of Delaware & rroy@tmadelaware.org & www.tmadelaware.org \\
\hline Transportation Management Association of Utah & jagraz@saltlakechamber.org & www.tmautah.org \\
\hline Transportation Solutions & amfrankel@transolutions.org & www.transolutions.org \\
\hline TREK Transportation Management Organization & ir@trekhouston.org & www.trekhouston.org \\
\hline Tysons Transportation Association, Inc. (TYTRAN) & tytran@aol.com & www.tytran.comm \\
\hline Upper Valley Transportation Management Association & len@vitalcommunities.org & www.vitalcommunities.org \\
\hline U.S. 36 Transportation Mobility Organization & debra.baskett@us36tmo.org & www.us36tmo.org \\
\hline VervoerCoordinatieCentrum (VCC) Schiphol & sam@schiphol.nl & www.vcc-schiphol.nl \\
\hline Voyagez Fute Montreal & brun@citemultimedia.com & www.citemultimedian.com \\
\hline Warner Center Transportation Management Organization & tmo@warnercenter.org & \\
\hline Westshore Alliance Transportation Management Organization & Keene@westshorealliance.org & www.westshorealliance.org \\
\hline Westside Transportation Alliance & dan@wta-tma.org & www.wta-tma.org \\
\hline Willingdon Corridor Transportation Action Group (BEST) & sam@best.bc.ca & www.best.bc.ca \\
\hline Yolo Transportation Management Association & bill@yolotma.org & www.yolotma.org \\
\hline
\end{tabular}


Appendix B: Considerations for Expanding the Survey to Include European Nations and Others 


\section{Transportation Management Association (TMA) Survey}

\section{A Worldwide Survey in 2008?}

In addition to Canadian TMAs, the survey was sent to known European contacts in an atte include European TMAs. However, responses from TDM professionals in Germany and ] observed that, with the possible exception of The Netherlands, the organizational structure delivering mobility management and TDM services is not similar to the TMA model used United States and Canada. The focus of the TMA Survey is upon the operational characte of those public/private partnerships particular to the U.S. and Canada. Despite this interest from our European counterparts in the results of the TMA Survey to learn more at organizational options for service delivery. Correspondingly, the recent completion of M( (Mobility Management Strategies for the Next Decades), a two-year project sponsol European Commission, contains research that could be very useful to the U.S. This incluc application of TDM to non-commute travel, specifically tourism, events and new sites in t planning stages; ways to integrate mobility management into transportation policies on all and the development of standardized monitoring and evaluation tools. The Chairm Board of Directors of the Association for Commuter Transport in the U.K. suggested the next TMA Survey should be broadened to include nations of the European Union. How $n$ this be accomplished?

The different manner of mobility management service delivery makes it not possible or re for European entities to respond to the survey in its current form. Even the analysis of Ca] TMAs presented in this report was drawn through the lens of a U.S. perspective. Might the conclusions from the data be different if the Canadian transportation researchers examinec same data? An international effort should, at the very least, begin with representatives of , nations having mobility management programs (in the U.S. we call it TDM-even vocabulary is different and therefore meanings may differ) convene and discuss wh undertaking should involve. This meeting should take place well in advance of su instrument development.

To broaden it to include other nations would require changing or broadening the focus survey to, perhaps:

1. Concentrate more upon application of the mobility management services and stratt themselves,

2. Collect performance data on TDM strategies across TMAs and other service pr and/or

3. Query the range of institutional and organizational forms used to deliver mc management services. 


\section{Transportation Management Association (TMA) Survey}

For example, the European approach to mobility management (MM), as described I transportation researcher in Germany, is based on individual entities that might be:

A single company offering services for their employees and clients

Schools offering services for the pupils

Hospitals caring for their employees, patients, and visitors

The municipal government for a whole city or region

The local public transportation provider for the region (currently undergoing privatiza in Germany and other nations) ${ }^{5}$

As the TMA Survey has already become an international endeavor, we must consider, are asking relevant and useful questions? What do we want to learn from the survey and how intend to apply what we learned? The broad aim is for study results to yield useful inform for all participants and that we can learn from each other's efforts and borrow what works

When the ACT TMA Council committee convenes to plan the next TMA Survey, the effort might begin with identifying what questions remain unanswered. The TMA Survey in its form is composed of 70 questions, many of which are complex to answer. Keeping it in its current form would preserve our (U.S.) ability to draw comparisons and chart trenc previous surveys. It might be pragmatic to consider grouping questions differently throug use of a companion survey or a different type of data collection instrument altogether.

At a minimum, certain areas should be reviewed and discussed by potential participants:

Scope of participation: U.S., Canada, United Kingdom, Germany, Italy, Netherlands, other European Union nations, New Zealand, Australia, Japan, others Vocabulary and the differing meaning of concepts across cultures.

Research instrument type: a survey or something else?

Instrument development in the native language of the nation as well as distribi collection and analysis by researchers from that nation. Convene a committee to c results. This might even include drafting slightly (or greatly) different sets of ques for different nations to use.

\footnotetext{
${ }^{5}$ Timo Finke, Institute for Urban and Transport Planning, Aachen University, Germany, email communication, January 31, 2003.
} 
Appendix C: Administering the 2008 TMA Survey in Its Current Form 


\section{Transportation Management Association (TMA) Survey}

\section{Improving the Next TMA Survey}

The following observations are offered, given the benefit of hindsight, as a point of departure fo the development and improvement of the next TMA Survey.

As part of the survey analysis process, the 2003 data was entered into an Excel spreadsheet for calculations of totals, ranges, means and medians. However, such an analysis method by itself introduces the risk of misinterpretation of the data by taking the data out of context. $\mathrm{T}$ information that we attempted to glean through the use of a survey was complicated in man respects. Respondents were challenged to answer accurately within the constraints of a limited number of answer options. The risk is that a complete answer was not provided, because the survey did not allow it, or it was too cumbersome to provide, introducing additional ris] misinterpretation. The "Others/Comments" questions introduced into the 2003 TMA Sur which were intended to clarify, may have caused confusion in some cases. For example, a few respondents had illegible handwriting and used abbreviations that were unknown. In other cases it was apparent from the responses that there were multiple interpretations of the question, whic] is caused either by vague or ambiguous wording of the question or by the use of differ definitions by the respondents. For example, it was apparent that respondents were using at leas five different definitions of TMA membership.

Part of the solution was to go back and look at the original survey to examine the collective answers of a TMA as a whole, to more accurately interpret the answers within the prof context, rather than just collectively computing from data entered into a spreadsheet. $\mathrm{Tl}$ following questions indicated some problems of interpretation.

12. Out of the entire potential membership base located within your TMA service area, percentage of these is actually represented as members on the TMA? This question does not reflect conditions of BIDs or CIDs, because all are members by requirement. It is mor question of how many companies/employers and/or office buildings actively participate in the TMA. This question should receive consideration for rewording.

20. Please list the number of persons employed by your organization. Consideration might be given to rewording the question thus: "Please list the number of persons employed by $y$ TMA.” This might eliminate from the figures, any staff that are employed by a parent organization but who have no relation to the TMA.

21/22. Does your TMA hire consultants or vendors for the direct provision of services? If yes, which services are contracted out? There was a change in the answer options for this question since 1993. Perhaps in the 2008 TMA Survey, there should be two questions distinguis 


\section{Transportation Management Association (TMA) Survey}

contracting out for TMA staffing and administrative services, from contracting out for the direct delivery of travel services.

33. Please estimate your expenditures breakdown for the most recently completed year. Survey planners might want to reconsider what we are trying to find out from this question. It appears from previous surveys that the purpose is to determine what percentage of a TMA's budget goes directly to member services. In 2003, it was approximately 24 percent as compared to 26 percer in 1993. The 2003 figure was based upon computing an average across all TMAs for "shuttles/transit operations" and "other direct member services." In addition, the answers several budget line items can range from zero to 97 percent, making the effort to compute a mea somewhat risky. What does a mean really tell us? These percentages could be misleac because every TMA may categorize budget items differently and because it could be argued that items within every budget line contain elements of a member service. For example, should the production and distribution of a vanpool brochure (under "marketing and promotion") not included as a direct member service? Commuters must be made aware of the service before the' can avail themselves of it. For future surveys, it would be useful to revisit this questic explore what we are trying to learn, so that the question can be better specified.

40. Does your TMA own or lease office space for its headquarters? There was some confusion with interpreting answers of TMAs who indicated they neither own, lease, nor receive donated office space. It is recommended that the next survey replace the answer option: "TMA does not own/lease office space” with “Other, please specify .”

46. Does your TMA conduct an annual full-membership meeting? Some responding no to the question could actually be conducting periodic meetings and providing the kind of reporting tha ordinarily takes place at annual meetings, but on a different schedule, such as biannually or ever 18 months, 2 years, as needed, etc. This question should be reworded.

57. How often is the full board of directors required to meet? There may be some ambiguity to this question in the sense that not all boards have a meeting frequency requirement. $\mathrm{Tl}$ responses may actually reflect how frequently boards actually meet. Perhaps there should be a part a. and part b. to find out both how often the board must meet as well as how often the board actually meets.

\section{Survey Format}

The initial intent was to provide the survey electronically by directing participants to a web link where the participant could easily fill out the survey and electronically submit it. How survey designers encountered two obstacles. First, the available technology could not allow a participant to scroll backward to modify an answer. Secondly, a participant would lose all data 


\section{Transportation Management Association (TMA) Survey}

entered if he or she chose to temporarily close the file. Because of the complexity of the survey we believed it was essential for a respondent to be able to scroll forward in the document to peruse the whole survey and scroll backward to modify answers. Additionally, because of the length of the survey, respondents needed to have the option to save what they initially entered and set it aside in order to come back and finish the survey at a later time. As a result of these limitations, instead of a web link to the survey, participants were emailed a survey in MS Word format, which could be filled in, then saved and emailed back or printed and faxed or sent back.

In addition, the best response rates to a survey will result from providing multiple formats from which participants can choose, including a hard copy. As a result, after the electronic copy was issued and the first wave of completed surveys was received, hard copies of the survey were sen to all who did not initially respond. Ultimately, over half of all surveys received were faxed or sent by U.S. Mail rather than returned electronically. Some survey participants conveyed that the electronic Word document was a clumsy format. In 2008, when the next TMA Survey is conducted, it is anticipated that recent issues relating to electronic survey administration have been resolved and more options will be available. It is recommended that the 2008 survey be administered electronically with hard copy follow-up.

\section{Ideas for Future Questions}

The 2003 TMA Survey was composed of 70 questions, many of which required the sur respondent to consult records and do some research to answer. The size and complexity of the survey is such that it is probably advisable not to go beyond 70 questions. The survey released January $9^{\text {th }}, 2003$ and while the final extended deadline was March $7^{\text {th }}$, surveys were received after that date and included in the study. For planning purposes, this experien suggests that it takes at least two full months to allow respondents to complete and return the survey.

However, there are still many other issues of interest that the TMA Council and TDM professionals might want to know. A list of brainstorming ideas follows here, for futur consideration by the next TMA Council committee for the 2008 TMA Survey. There are at leas three ways to address the problem of survey length and complexity:

Develop a companion survey and alternate their use so that a survey is administere every five years but data for any particular question is collected only once every years.

Develop a companion survey and alternate their use so that a survey is administerer every two or three years and the data for any particular question is collected once every five years. 


\section{Transportation Management Association (TMA) Survey}

Evaluate which questions from the 2003 TMA Survey could be eliminated to make ro for other questions of interest, and continue to administer the survey every five yec

\section{Question Topics}

\section{Membership}

The questions in the section on Membership should be updated to reflect the $\mathrm{s}$ community improvement districts (CID) and business improvement districts ( Affected questions include membership size, member recruitment, income sources rates are assessed, and service area scope.

In the future, survey questions about board membership, company/employer members and size of travel markets might be grouped together so that the respondent will $\mathrm{m}$ ! readily make the distinction among these categories.

In survey questions where not all agree on the same definition, such as memb provide a definition of that which is desired to be measured.

\section{Services}

Have TMA service area boundaries been redrawn in the last five years to expand or $n$ smaller? Is the increasing number of commuters served due to greater densificatio the service area or due to expanding the boundaries of the service area?

Degree of success of services, member and customer satisfaction, or tren improvement of programs

Service offerings:

o Linking information to appropriate markets, including real time information

o Developing services that promote community livability

o Fostering communication between TMA members and policymakers

o Probing new markets for transit

o Conducting data collection/data validation

\section{Personnel}

Performance review of support staff

Activities undertaken to help staff recharge creativity and renew sense of purpose, suc as retreats

Professional development and training activities undertaken by staff 


\section{Transportation Management Association (TMA) Survey}

\section{Organization}

Board member motivations for serving on the TMA board. During the planning for the $2 \mathrm{C}$ TMA Survey, one idea was for a second survey to be distributed to TMA board I through the executive director. This idea was ultimately not pursued. It was thought to be burdensome on the TMA director to secure agreement of all the board members to comple survey, then collect them and send them back to the survey administrator. Howev recommended that the survey planners for the 2008 TMA Survey consider ways in information can be obtained about TMA boards. While we know what entities are represe on boards, very little is known about the factors that motivate individuals to serve boards. Because the participation of individuals to serve on TMA boards is central to the of TMAs, it is important for future research on TMAs to find ways to capture this informa might be obtained in a survey sent directly to board members of those TMAs whe incorporated as non-profit organizations. Board member addresses could be obtained thro the IRS Form 990. However, it was also a consideration that TMA executive directors mi prefer to be the contact point through which correspondence for TMA board members is $\mathrm{r}$. Possible questions for surveying TMA board members might include:

Company affiliation

What skills do you bring to the TMA?

What constituents do you represent?

Do you currently hold an office? Which?

Which past offices have you held?

What committees do you serve on?

How long have you been a board member?

What do you hope to accomplish as a board member?

Has the TMA met your expectations?

How does your company benefit from your participation in the TMA?

How do you personally benefit from participation in the TMA?

What do you like least about the TMA?

What do you like most about the TMA?

What is your motivation for participating on the board?

Do other branches of your company participate in a TMA?

What resources or conditions would enable your TMA do a better job? 


\section{Transportation Management Association (TMA) Survey}

\section{External Relationships}

Identification of useful allies

Activities to strengthen support for TMAs

Instances where it was important to let others take credit for the work accomplished b the TMA

Does your TMA serve on the MPO board or technical coordinating committee? 
Appendix D: Letter of Invitation to Participate in the 2003 TMA Survey 


\section{Transportation Management Association (TMA) Survey}

January 2, 2003

RE: $\quad 2003$ TMA Survey

TO: $\quad$ All Executive Directors of Transportation Management Associations

It is my pleasure to invite you to participate in the 2003 Transportation Management Association (TMA) Survey, which was conducted previously in 1993, and again in 1998. This is an important opportunity to share information about your TMA. The collective survey findings will provide useful information to you and other TMAs about the range of activities and characteristics of TMAs nationally and internationally. While this survey is being conducted in cooperation with the Association for Commuter Transportation (ACT), we urge all TMAs to respond to the survey, including TMAs that are not ACT members.

“Am I a TMA?” According to the TMA Handbook:

A Transportation Management Association (TMA) is an organized group applying carefully selected approaches to facilitating the movement of people and goods within an area. TMAs are often legally constituted and frequently led by the private sector in partnership with the public sector to solve transportation problems.

If your organization fits within this definition, we encourage you to participate in the TMA Survey!

The TMA Survey is research being funded by the federal government and conducted through the National TDM and Telework Clearinghouse, a project of the National Center for Transit Research (NCTR) at the University of South Florida in Tampa. The goal of the study is to collect and analyze survey data to better understand national and international trends in the development and operations of TMAs.

We located you through one of several sources, including the ACT member database, the ACT TMA Council contact list, Internet research, a database of the National TDM and Telework Clearinghouse, contact with state departments of transportation, a question posted to the TDM listserv and through numerous inquiries to peers in the profession.

Participation in this survey is completely voluntary. There are no perceived risks associated with your participation and you will not be paid for your participation. Your participation implies informed consent. If you agree to participate, the information you provide will be used to develop a summary report that will be distributed through ACT and NCTR. The summary report will be a public document, available free to all TMA survey participants, ACT members, and purchasers of the TMA Handbook. A nominal fee may be charged to all others to cover the cost for printing and shipping.

The survey results also will be published in the ACT publication, TDM Review, and presented at the International 2003 TMA Summit in Montreal, Canada, May 4-6, 2003 (visit www.actweb.org for more 


\title{
2003 Transportation Management Association (TMA) Survey
}

event information). Only the National Center for Transit Research at the University of South Florida will have access to the raw data that you provide. Your employment title and TMA name may be used in the report, but your individual name will not be used.

If you have any questions regarding participation in this survey, please contact Sara Hendricks at (813) 974-9801 or by email at hendricks@cutr.usf.edu. If you have any questions about your rights as a person who is taking part in a research study, you may contact a member of the Division of Research Compliance of the University of South Florida at (813) 974-5638.

You can fill out the survey by accessing the weblink below and submitting your completed survey electronically. You may also print out a hard copy of the survey and send it or fax it to the attention of Sara Hendricks at:

\author{
Center for Urban Transportation Research \\ University of South Florida \\ 4202 E. Fowler Avenue, CUT100 \\ Tampa, FL 33620-5375 \\ FAX (813) 974-5168
}

Or if you prefer, we can mail you a hard copy of the survey for you to return by fax or U.S. mail. It is expected that the survey will take approximately 30 minutes to complete.

The deadline for completing the survey is February 14, 2003. Thank you very much and we look forward to your participation!

Sincerely,

Sara J. Hendricks

Research Associate

National TDM and Telework Clearinghouse

cc: $\quad$ Stuart Anderson
ACT Executive Director 


\section{Appendix E: 2003 TMA Survey Questions}




\section{Background Information}

1. TMA Name:

2. Mailing Address

3. Phone / Fax

4. Director Name and Title

5. Email

6. Website address 


\section{Transportation Management Association (TMA) Survey}

\section{Membership}

7. What is the composition of your membership? (Percent of total members, not travel markets)

\% Government employers (seeking commuter choice programs for government employees)

\% Government agencies (sponsoring or developing commuter choic programs for the general public) $\%$ Developers

$\%$ Property owners

$\%$ Individuals

$\%$ Non-profit

$\%$ Residential or community association

$\%$ Other organizations Please list:

\% Other Please identify:

8. How many members does your TMA represent?

9. How does your organization recruit members? Check all that apply.

Contact from Executive Director

Contact from a Board Director

'Cold Calling' for an individual meeting with the Executive Director

Brochure/Packet of information widely distributed

Peer-to-peer recruitment (members recruit new members from peer organizations Mandatory membership/Travel Reduction Ordinance

Joint membership in Chamber of Commerce/TMA

Invitation to TMA-sponsored workshops/meetings

Presentations by Executive Director/Board members at business organization meetings (e.g., Chamber of Commerce, trade associations)

Other Please describe: 


\section{Transportation Management Association (TMA) Survey}

10. Which method for recruiting membership do you view as most successful? Check c one.

Contact from Executive Director

Contact from a Board Director

'Cold Calling' for an individual meeting with the Executive Director

Brochure/Packet of information widely distributed

Peer-to-peer recruitment (members recruit new members from peer business organizations)

Mandatory membership/Travel Reduction Ordinance

Joint membership in Chamber of Commerce/TMA

Invitation to TMA-sponsored workshops/meetings

Presentations by Executive Director/Board members at business organization meetings (e.g., Chamber of Commerce, trade associations)

Other Please describe:

11. a). Approximately how many new members did you recruit last year?

b). Approximately how many members did you lose last year?

12. Out of the entire potential membership base located within your TMA service area percentage of these is actually represented as members on the TMA? Also include this percentage, all employers who lease office space from property owners who are members on the TMA. $\%$

13. Are there any other comments you would like to add that describe the membership your TMA or to clarify any information you provided above? 


\section{Transportation Management Association (TMA) Survey}

\section{Services}

14. Approximately how many of each of the following types of travel target markets d TMA currently serve? Please round to the nearest 100.

Commuters
Students
Residents

Visitors/Shoppers/Tourists
Other Please describe
Other Please describe

15. What is the geographic scope of the TMA's service area? Check only one.

Regional / Multiple jurisdictional

Citywide / One jurisdiction

Corridor

Central Business District

Suburban / Fringe Activity Center

Specialized Activity Center (such as large development complexes relating to universities, tourist attractions, hospitals, airports, or an industry)

Other:

16. Check which of the following services your TMA offers, including contracted serv from a third party.

SERVICE (1)

ETC training

Rideshare matching

Telecommuting program

assistance

Subsidized transit passes

Direct rideshare incentives

$\begin{array}{ccc}\text { A: Provided to } & \text { B: } \text { Provided to } & \text { C: } \text { Provided } t \\ \text { members } & \text { non-members } & \begin{array}{c}\text { non-mer } \\ \text { at higher pric }\end{array}\end{array}$




\section{Transportation Management Association (TMA) Survey}

Shuttle/Local transit provision

Direct shuttle service operation

Guaranteed Ride Home

Vanpool services

Vanpool subsidy program

Regional/Local advocacy

Site design assistance

Trip reduction plan preparation

Parking service provision

Parking pricing and/or

management

Promotional

materials/newsletters

Promotional events

Tax benefit program assistance

Carshare Program

Bicycle Program

Other

17. Does the TMA conduct any of the following types of program or service evaluation or assessment activities? Please check all that apply.

Track calls/emails received in response to marketing/outreach activities Survey members to assess satisfaction with TMA programs, ideas for future services 


\section{Transportation Management Association (TMA) Survey}

Survey commuters and others who use TMA services to assess service effectiveness or "placement” (e.g., measure number of service users who shift to/are "placed in" alternative modes after using services)

Survey employers, commuters, or others who use TMA services to assess satisfaction with the services

Other

Other

None

18. How often are these evaluations or assessments conducted? Check only one.
Annually
Every two years
Varies by evaluation activity
Ongoing tracking
Other
Have not conducted evaluations

When new services are implemented (to assess use or effectiveness)

19. Are there any other comments you would like to add that describe the services of your TMA or to clarify any information you provided above? 


\section{Transportation Management Association (TMA) Survey}

\section{Personnel and Policies}

20. Please list the number of persons employed by your organization:

Full-time permanent

Part-time permanent

_ Contract employees (not including consultants and vendors)

Volunteers

21. Does your TMA hire consultants or vendors for the direct provision of services?

YES

NO

22. If yes, which services are contracted out? Check all that apply.

Shuttle/Local Transit

Ridematching

Vanpooling:

Other: $\mathrm{n} / \mathrm{a}$
Parking Management

Site Design Assistance

Telecommuting program assistance

23. What is the professional background of your TMA's Executive Director? Place a 1 for primary experience, $\mathbf{2}$ for secondary experience, $\mathbf{3}$ for tertiary experience.

\begin{tabular}{|c|c|}
\hline Transportation planning & Marketing \\
\hline Transportation engineering & Public relations \\
\hline Transportation operations & Public service \\
\hline Administrative & Sales \\
\hline Planning & Finance \\
\hline Government management & Non-profit/association \\
\hline Other: & management \\
\hline Other:_ & Other: \\
\hline
\end{tabular}




\section{Transportation Management Association (TMA) Survey}

24. What is the educational background of your TMA's Executive Director? Place a 1 major degree, 2 for minor degree.

Transportation planning

Transportation engineering Social Science

Administration Planning

Public management Other:

Marketing
Public relations
Non-profit management
Sales
Finance
Other

25. Which degrees has your TMA Executive Director obtained? Check all that apply.

High School Diploma/GED

Associate Degree:

Bachelor of Science / Arts / Business

Master of Public Policy / Planning / Administration / Non-profit management

Master of Business Administration

Master (other):

Doctor of Philosophy:

Doctor of Jurisprudence 


\section{Transportation Management Association (TMA) Survey}

26. Check the salary range that most accurately reflects the salary of the Executive Dir and other key staff members.

SALARY RANGE

Less than $\$ 20,000$

$\$ 20,000$ to $\$ 29,999$

$\$ 30,000$ to $\$ 39,999$

$\$ 40,000$ to $\$ 49,999$

$\$ 50,000$ to $\$ 59,999$

$\$ 60,000$ to $\$ 69,999$

$\$ 70,000$ to $\$ 79,999$

$\$ 80,000$ to $\$ 89,999$

$\$ 90,000$ to $\$ 99,999$

More than $\$ 100,000$

Number of years with your TMA

(cumulative, all positions)

Number of years in TDM
Executive

Director
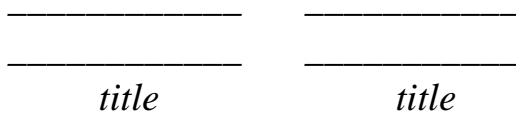


\section{Transportation Management Association (TMA) Survey}

27. Check any of the following benefits that are available for TMA staff. Check all tha apply.

Free parking

Professional membership dues

Seminars

$401(\mathrm{k})$ retirement

403 (b) retirement

$407(\mathrm{k})$ retirement

Cafeteria benefit plan

Maternity / Family leave

Life insurance

Transportation

allowanceMedical insurance
Dental or Vision insurance

Disability insurance

Paid holidays

Daycare for children

Employee assistance program

Subsidized transit passes

Tuition assistance

Incentive or cash bonus system

Section 125 (flexible spending)

Credit Union membership

Other:

28. The above benefits are paid for (Check one):

From the TMA budget

By the parent organization of the TMA

By other: Please specify:

29. a). Is your TMA staff guided by an adopted personnel policy document?

YES

NO

b). If yes, the personnel policy document was drafted and is administered by: Please ch only one.

The TMA staff

The parent organization of the TMA

By other: Please specify:

$\mathrm{n} / \mathrm{a}$

30. a). Are TMA employee evaluations conducted?

YES

NO 


\section{Transportation Management Association (TMA) Survey}

b). If yes, the employee evaluations are conducted by: Please check only one.

The TMA staff and board of directors

The parent organization of the TMA

By other: Please specify:

$\mathrm{n} / \mathrm{a}$

31. Are there any other comments you would like to add that describe the personnel ar policies of your TMA or to clarify any information you provided above? 


\section{Transportation Management Association (TMA) Survey}

\section{Financial Characteristics}

32. What were your TMA's expenditures for the most recently completed year? Chect one.

Less than $\$ 50,000$

$\$ 50,000$ to $\$ 74,999$

$\$ 75,000$ to $\$ 99,999$

$\$ 100,000$ to $\$ 149,999$

$\$ 150,000$ to $\$ 199,999$

$\$ 200,000$ to $\$ 249,999$
$\$ 250,000$ to $\$ 299,999$

$\$ 300,000$ to $\$ 499,999$

$\$ 500,000$ to $\$ 749,999$

$\$ 750,000$ to $\$ 999,999$

$\$ 1$ million or more

33. Please estimate your expenditures breakdown for the most recently completed yeal Where applicable, include labor, equipment, supplies and products for each item.

$\%$ Office operations (including office space, insurance)

$\%$ Marketing and promotion

$\%$ Shuttles/transit operations

$\%$ Other direct member services

$\%$ Professional services (legal, accounting)

$\%$ Travel

$\%$ Communications (phone, web, postage)

\% Other Please identify:

34. What percentage of your TMA=s income is derived from the following sources for most recently completed year?

$\%$ Member dues

$\%$ Fees for services

$\%$ Service contracts

$\%$ Developer funding agreements

\% Business improvement district

$\%$ Community financing district
\% Federal grants

$\%$ State grants

$\%$ Local grants

$\%$ In-kind donations

$\%$ Other

$\%$ Other 


\section{Transportation Management Association (TMA) Survey}

35. On what basis is annual membership dues assessments structured? Check and desci all that apply. If the options below do not enable an accurate description of your TMA dues structure, please mail or fax a schedule of dues rates for all member categories to Sara Hendricks.

No dues
Flat/Fixed rate
Flat/Fixed rate
Assets
Square footage
Negotiated based on size of project
$\begin{aligned} & \text { Parking space } \\ & \text { Number of employees }\end{aligned}$

36. Do you offer discounts to any of the following members or member groups?

$\mathrm{n} / \mathrm{a}$

New members

Long-time members (e.g., after 3 years or 5 years of membership)

Government agencies

Non-profits

Individuals

Other Please specify:

37. Are your TMA's financial records audited annually?

YES NO

38. Does your TMA provide an annual financial statement to members?

YES NO 


\section{Transportation Management Association (TMA) Survey}

39. What method of accounting is used to generate the TMA's financial records?

Cash

Accrual

Combination

Other:

Do not know; accounting conducted by parent organization

40. Does your TMA own or lease office space for its headquarters?

TMA owns entire/part of building and occupies it for its headquarters

TMA leases space in a building at discounted rate

TMA leases space in a building at full market rate

TMA receives donated space in a member=s building

TMA does not own/lease office space

41. Are there any other comments you would like to add that describe the financial characteristics of your TMA or to clarify any information you provided above? 


\section{Organization}

42. What types of organizations were instrumental in forming your TMA? Check all tr apply.

Employers

Developers

Transportation government agency

Environmental government agency

Metropolitan planning organization

Community/residential organizations

Other

43. What issues or concerns prompted the formation of your TMA?

44. What is your TMA's mission statement?

45. What type of authority decides final actions for the TMA? Check only one.

An authority comprised only of the membership (i.e., board of directors)

A combination comprised of membership and local government

Chamber of Commerce

Transportation/Local Improvement District

Appointed officials / Special committee

Other Please specify:

46. Does your TMA conduct an annual full-membership meeting?

YES NO

47. When was your TMA formed (month/year)?

48. a) Is your TMA incorporated?

YES NO 


\section{Transportation Management Association (TMA) Survey}

If you answered YES, what is the tax status of your TMA?

$$
\begin{aligned}
& 501 \text { (c) (3) } \\
& 501 \text { (c) (4) } \\
& 501 \text { (c) (6) }
\end{aligned}
$$

Other:

not tax exempt

b) If you answered NO to question 48a), is your TMA a subsidiary of or part of a parent organization (e.g., a program within a chamber of commerce or a business improvement district)?

YES NO

c) If you answered YES to 48b), what is the tax status of your parent organization under the Internal Revenue Code?
501 (c) (3)
501 (c) (6)
501 (c) (4)
Do not know

$501(\mathrm{~h})$

Other:

49. If you answered YES to 48b), what type of parent organization sponsors your TMA? Check only one.

Business improvement district

Chamber of commerce

University

Community financing district

Other

50. How many voting members are on your TMA's governing board?

51. How many non-voting members are on your TMA's governing board?

52. Please list non-voting Board members.

$\begin{array}{ll}\text { State DOT } & \text { MPO } \\ \text { Transit agency } & \text { County } \\ \text { City } & \text { TMA Executive Director } \\ \text { Other } & \text { Other } \\ \text { Other } & \text { n/a }\end{array}$

53. How long is a term of office for a board member? Check one. year(s)

Term duration not defined 


\section{Transportation Management Association (TMA) Survey}

54. What is the maximum number of terms that a Board member may serve? Check or term(s)

No term limits

55. How long is a term of office for a Board officer (e.g., Chair, President)? Check ont year(s)

Term duration not defined

56. What is the maximum number of consecutive terms that a board member may hold officer position? Check one. term(s)

No term limits

57. How often is the full board of directors required to meet? Check one. time(s) per year no requirement

58. How do you fill Board positions? Check all that apply.

Determine all constituent groups that you need to impact.

Identify the gaps in skill and expertise representation between the current Board and the future Board

Identify the critical areas of commitment that each board member should consider before accepting a board seat (e.g., attendance, financial support, advocacy)

Target prospects for peer-to-peer recruitment

Seek nominations from outside organizations (e.g., community leadership development programs)

Other Please describe:

Other Please describe:

None of the above.

59. How do you provide Board training? Check all that apply.

Provide new Board member orientation and training

Provide a Board Member Manual

Other

The TMA does not conduct Board training. 


\section{Transportation Management Association (TMA) Survey}

60. Which of the following activities are considered responsibilities of Board members, either in whole or in part? Check all that apply.

Member recruitment

Strategic planning

Work plan development

Financial planning

Financial oversight

Other Please describe:

None of the above

61. Which of the following documents does your TMA maintain? Check all that apply.

Mission Statement

Objectives

Strategic Plan

Annual/biennial work plan

Other Please specify:
Bylaws

Policies and Procedures Manual

Employment Manual

None of the above

62. If your TMA maintains a Strategic Plan, how often does your governing body review and update the plan? Check only one.

Once a year

Twice a year

Every other year
Never

Other

$\mathrm{n} / \mathrm{a}$

63. Does your TMA retain any of the following insurance? Check all that apply.

Officers and directors insurance

Fiduciary liability insurance

None of the above
Professional liability insurance

Other:

64. What type of policy or service committees operate within your TMA? Check all that apply.

Executive Committee

Long Range Planning

Administrative

Media/Public Relations

Legal

Membership/Recruitment

Other:
Budget/Finance

Project specific

Government Affairs/Advocacy

Personnel/Human Resources

Publications

Convention/Annual Meeting

Other: 


\section{Transportation Management Association (TMA) Survey}

Other:

Other:

65. Does your TMA retain legal counsel?

YES

NO

66. If yes, what relationship do you maintain? Check only one.

Attorney on staff

Hire on a per job basis

Volunteer from membership

Other
Annual retainer with supplement Annual retainer for all services

$\mathrm{n} / \mathrm{a}$

67. Does your TMA require the presence of legal counsel at board meetings?

YES NO

68. What issues, if any, have required legal counsel over the past year? Check all that apply.

Tax filing

Insurance (general)

Incorporation

Personnel issues

None of the above
Directors and officers insurance Lawsuits

Review of contracts/agreements Other

69. Which of the following technology-based activities or communication strategies di your TMA support? Check all that apply.

Website

Web-based surveys

Email distribution lists

None of the above
Dial-up Bulletin Board System

On-line ride matching

Other:

70. Are there any other comments you would like to add that describe the organization your TMA or to clarify any information you provided above?

THANK YOU FOR COMPLETING THE 2003 TMA SURVEY. 